Review

\title{
An overview of Structured Biosensors for Metal Ions Determination
}

\author{
Diogo L. Rocha ${ }^{1, * \mathbb{C}}$, Vivian Maringolo ${ }^{1} \mathbb{D}$, Alberto N. Araújo ${ }^{2}$, Célia M. P. G. Amorim ${ }^{2} \mathbb{D}$ \\ and Maria da Conceição B. S. M. Montenegro ${ }^{2} \mathbb{D}$ \\ 1 Center on Natural Sciences and Humanities, Federal University of ABC, Santo André 09210-580, Brazil; \\ vivian.maringolo@ufabc.edu.br \\ 2 Department of Applied Chemistry, LAQV-REQUIMTE, Faculty of Pharmacy, University of Porto, \\ 4050-313 Porto, Portugal; anaraujo@ff.up.pt (A.N.A.); camorim@ff.up.pt (C.M.P.G.A.); \\ mcbranco@ff.up.pt (M.d.C.B.S.M.M.) \\ * Correspondence: d.rocha@ufabc.edu.br
}

check for updates

Citation: Rocha, D.L.; Maringolo, V.; Araújo, A.N.; Amorim, C.M.P.G.;

Montenegro, M.d.C.B.S.M. An overview of Structured Biosensors for Metal Ions Determination. Chemosensors 2021, 9, 324. https:// doi.org/10.3390/chemosensors9110324

Academic Editor: Maria Cuartero

Received: 26 October 2021

Accepted: 16 November 2021

Published: 18 November 2021

Publisher's Note: MDPI stays neutral with regard to jurisdictional claims in published maps and institutional affiliations.

Copyright: (c) 2021 by the authors. Licensee MDPI, Basel, Switzerland. This article is an open access article distributed under the terms and conditions of the Creative Commons Attribution (CC BY) license (https:/ / creativecommons.org/licenses/by/ $4.0 /)$.

\begin{abstract}
The determination of metal ions is important for nutritional and toxicological assessment. Atomic spectrometric techniques are highly efficient for the determination of these species, but the high costs of acquisition and maintenance hinder the application of these techniques. Inexpensive alternatives for metallic element determination are based on dedicated biosensors. These devices mimic biological systems and convert biochemical processes into physical outputs and can be used for the sensitive and selective determination of chemical species such as cations. In this work, an overview of the proposed biosensors for metal ions determination was carried out considering the last 15 years of publications. Statistical data on the applications, response mechanisms, instrumentation designs, applications of nanomaterials, and multielement analysis are herein discussed.
\end{abstract}

Keywords: metallic element determination; biosensing; biochemical sensors; nanomaterials

\section{Introduction}

According to the International Union of Applied Chemists (IUPAC), biosensors are devices that mimic biological conditions by mediating biochemical reactions between the analytes and the biological recognition element (enzymes, immunosystems, tissues, organelles, and whole cells) kept in direct contact with a transducer, yielding an optical, electrical or thermal signal [1]. They are constructed by coupling biomolecule(s) to a transducer aiming at the conversion of a biochemical process into a physical output. This definition is still following a biotechnological glossary published in 1992 [2]. Definition updates are desired once other mechanisms that yield biological responses are nowadays exploited with biosensors [3]. A wider definition was proposed by a review article that described biosensors as compact analytical devices with incorporated biological or biologically derived recognition systems for analyte quantification [4], which is suitable considering the design of the developed sensor and other types of responses (e.g., piezoelectric and acoustic detection).

The interaction of metal ions with some biorecognition molecules allows the quantification of these elements using biosensors. In some cases, speciation $[5,6]$ and multielement analysis [7-19] are reached by exploiting several biochemical processes in the same system or the same type of interaction for different analytes. Possible biochemical responses result from the conformational changes of proteins, the quenching or emission of fluorophores, spectroscopic shift, and the enhancement or hindrance of the combination of DNA strands [20]. Determinations carried out with biosensors overcome some drawbacks of other strategies for element analysis based on techniques such as atomic absorption spectrophotometry (AAS) [21], atomic fluorescence spectrometry (AFS) [22], inductively coupled plasma atomic emission spectrometry (ICP OES) [23], inductively coupled plasma mass spectrometry (ICP-MS) [24], and X-ray fluorescence spectrometry [25]. 
Mainly, biosensors show lower costs of acquisition and maintenance, lower detection limits without prolonged sample preparation steps, and adequate selectivity [26]. In many cases, biosensors have been applied to the accurate determination of elements at trace and ultra-trace levels [25]. Despite the usual low detection limits of electrochemical techniques, interferences among metal cations have been generally reported and the addition of masking agents, for example, is sometimes necessary to circumvent drawbacks [27]. By modifying electrodes with biocomponents, selectivity is enhanced in a simple and environmentally friendly way [25]. Additionally, biosensors are generally easily miniaturized, contributing to the development of in situ and automated procedures $[3,28]$ with minimum sample preparation.

Inorganic element analysis is important because it comprises the determination of essential ionic nutrients for the maintenance of life. Biological systems depend on compounds with metal ions as determinants of their structure (e.g., cytochrome) or as essential participants of biochemical reactions. Manganese, copper, and iron compose the chemical structure of important biological compounds, such as superoxide dismutases [29] and hemoglobin [30]. Relevant examples of the essential participants of biochemical reactions are nickel, zinc, and magnesium. The latter acts as a charge shielding ion in ATP reactions [31]. Inorganic salts with low solubility also show their importance in biological systems. Calcium phosphate is the main constituent of bone and teeth structures [32] and provides a primary source of phosphorus in plant cells [33]. Due to the variable concentrations of these nutrients in the biological system of humans, daily maximum ingestion is recommended, which varies from thousands of milligrams, e.g., of calcium [32], to a few micrograms, such as in the case of chromium(III) [34]. However, the excess of essential metal cations can lead to system disorders such as renal and neurological diseases that might be a consequence of the excessive ingestion of calcium [32] and manganese [29], respectively.

Harmful metal ions such as mercury, cadmium, lead, and chromium(VI), do not show nutritional values and pose a major public health concern according to the World Health Organization (WHO) [35]. Thus, legal limits have been established for these elements in environmental and food samples. According to WHO guidelines [35], the safe recommended limits for $\mathrm{Cd}, \mathrm{Hg}, \mathrm{Pb}$ and total $\mathrm{Cr}$ in drinking waters are 3.0, 6.0, 10, and $50 \mu \mathrm{g} \mathrm{L}^{-1}$, respectively.

Considering the abovementioned highlights of metal cations acting as essential and toxic agents in biological systems at low concentrations, the development of reliable and sensitive analytical procedures with adequate selectivity can be achieved with biosensors. Thus, this article aims to provide a critical overview on the development of biosensors for metal ions analysis, with electrochemical, optical, and piezoelectric transductions proposed in the last 15 years. Procedures based on the immobilization or entrapment of biorecognition species on solid platforms were included in this review, excluding, however, strategies that considered suspensions of nanomaterials as biosensors. Previous reviews on enzyme-based electrochemical (bio)sensors $[20,25]$ were focused on heavy metals analysis. Therefore, interesting works not mentioned elsewhere, including those discussing sensors with non-electrochemical responses, are also herein discussed.

\section{General Aspects and Statistics}

Chemical analyses are generally a high demand task in analytical laboratories. Thus, sensitive, cheap, fast procedures that require simple instrumentation are sought. In this context, biosensors meet these requirements compared to other strategies for the detection of metallic elements. In the past 10-15 years, over 150 articles focusing on biosensors for metal ions analysis have been published, according to a survey of the ISI Web of Knowledge database. These data were displayed in Figure 1, which shows that despite the decrease in the number of publications since 2015, there were over 3400 citations, with an average of 25 citations per article and an h-index of 35. Before 2013, less than 25 articles had been published with this aim. Since 2014, the number of citations showed a ca. 550\% 
increase and increments between 18 and $112 \%$ were observed yearly until 2020. These data demonstrate the trends in the studies of biosensors for metal ions analysis. Despite 2020 being an atypical year, in which the attention of biological research was redirected to resolving other emerging issues, the numbers of publications and citations still increased.

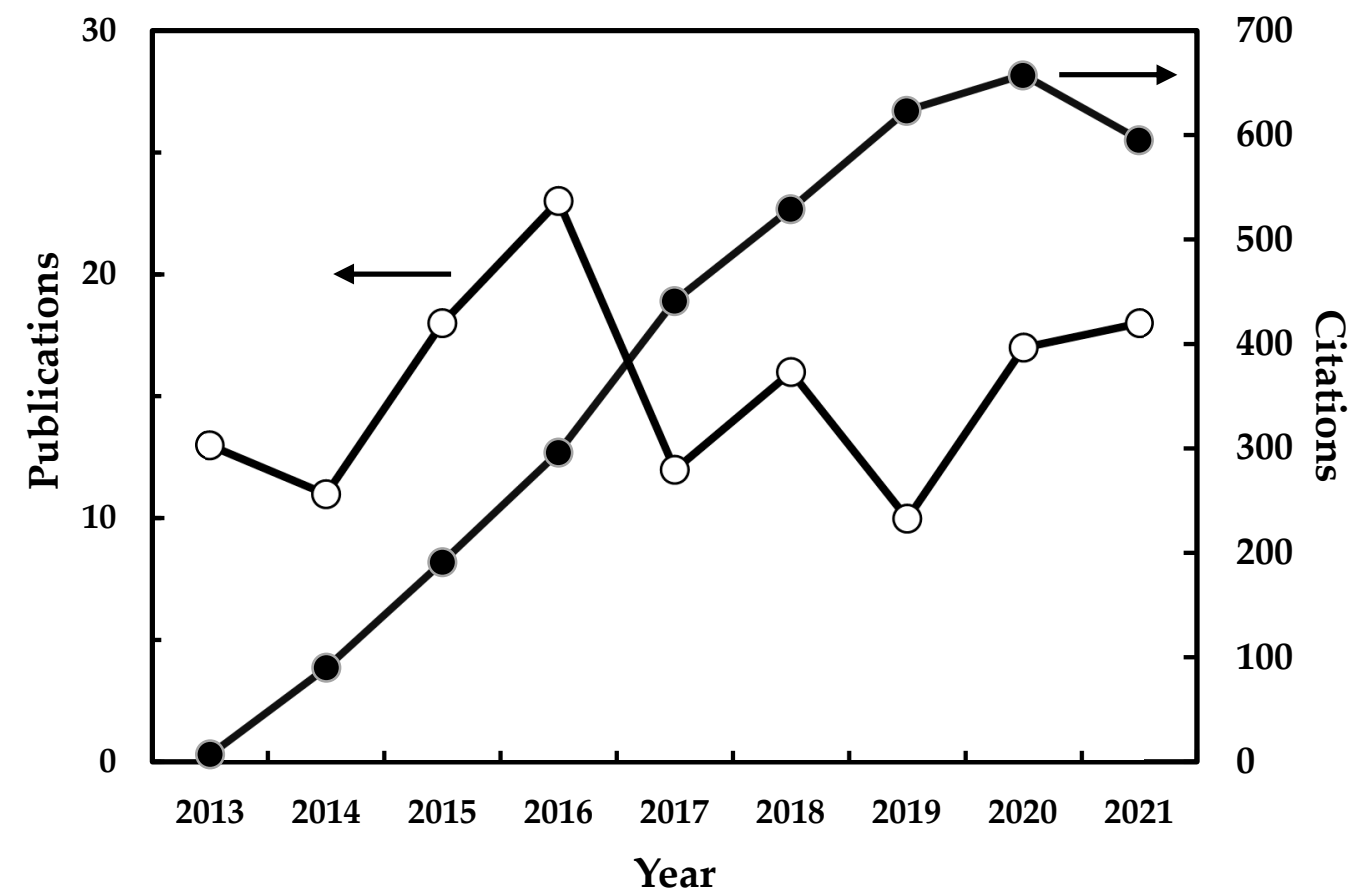

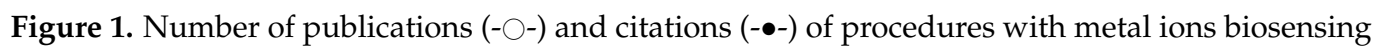
since 2013. Data were retrieved from ISI Web of Knowledge.

The most frequent metal ion determinations were $\mathrm{Pb}(\mathrm{II}), \mathrm{Cu}(\mathrm{II}), \mathrm{Hg}(\mathrm{II})$, and $\mathrm{Cd}(\mathrm{II})$, comprising $98 \%$ of the publications considered herein (Figure 2a). Some of the developed biosensors were applied to the determination of multiple analytes, yielding a sum higher than $100 \%$, as shown in Figure $2 \mathrm{a}$. The interest of each metal ion is also demonstrated by each percentage in the considered database. Among the metals indicated in Figure $2 \mathrm{a}, \mathrm{Cu}(\mathrm{II})$ has been a target ion for the development of biosensors because cupric ions easily coordinate with biomolecules, such as proteins, with multiple amino groups in their structure. Likewise, biosensors for $\mathrm{Cd}(\mathrm{II}), \mathrm{Hg}(\mathrm{II})$, and $\mathrm{Pb}$ (II) were developed based on their bonding to the nitrogen bases of DNA strands. Along with other analytes, such as $\mathrm{Ni}(\mathrm{II})$ and $\mathrm{K}(\mathrm{I})$, DNA-based sensors comprise over $50 \%$ of the proposed procedures for metal ion biosensing due to the use of variable strategies.

Environmental analysis requires analytical procedures with low limits of quantification due to the threshold limits of hazardous metal ions [35], which can be achieved with biosensors, especially with electrochemical transduction. The analysis of tap, drinking, river, well, and lake waters comprised $75 \%$ of the proposed procedures (Figure $2 \mathrm{~b}$ ). This is a consequence of the problematic presence of toxic metal ions in environmental samples and their bioaccumulation. Biological fluids, food, soil, and wastewater analysis have also been exploited, comprising 34\% of the surveyed data. Most of applications were directed to liquid samples, such as plasma/serum [7,9,36-45], juices [9], and wastewaters [46-56].

It is important to point out that, according to Figure $2 b$, almost a quarter of the proposed biosensors were not applied to real samples in view of their lack of selectivity. The significance of the studies carried out regarding the detection of metal ions justifies, nonetheless, the argument that the real application of procedures should still be sought. In that scope, sample preparation can be further evaluated to enhance important analytical features such as selectivity. In those cases where trace analysis was feasible, even microdi- 
gestion [57], i.e., decomposition using micro amounts of sample and reagents, could be employed as a fast and clean step for sample preparation.

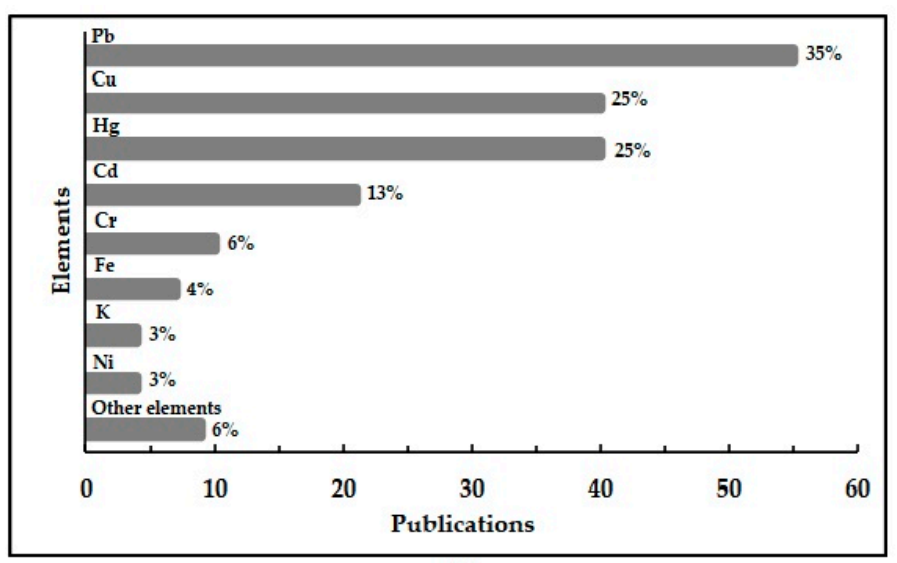

(a)

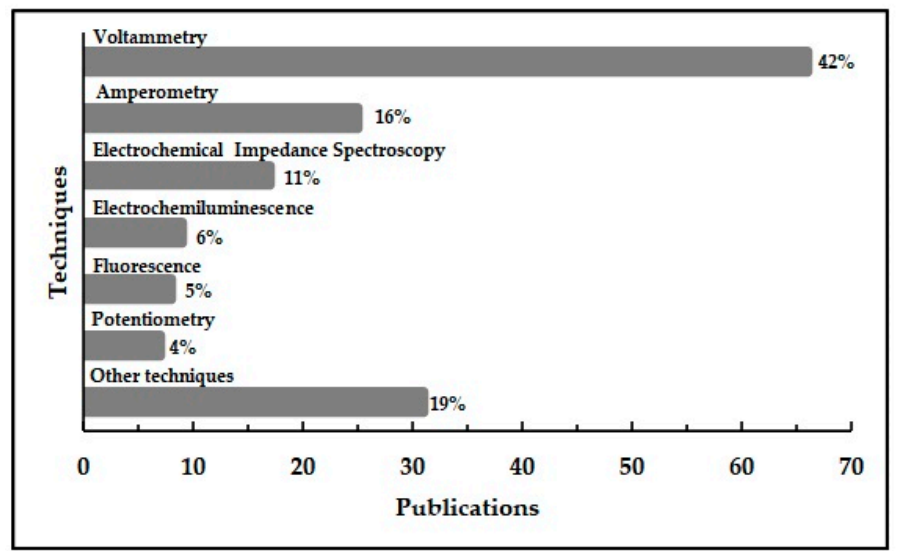

(c)

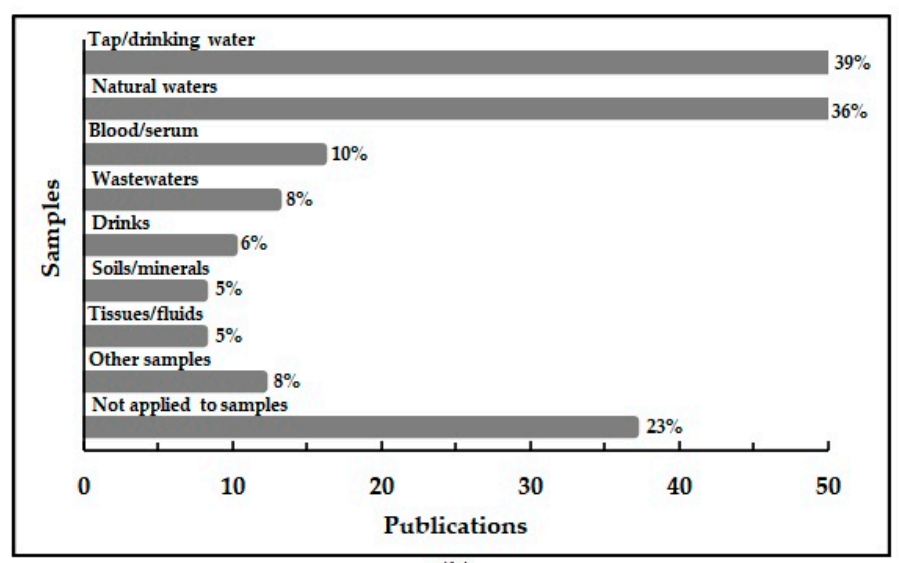

(b)

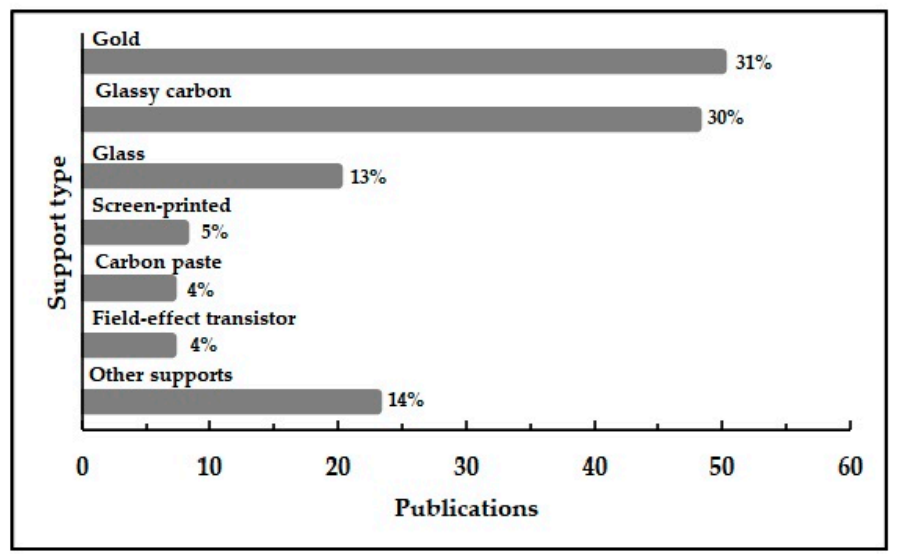

(d)

Figure 2. Overview of the applications of biosensors for metal ions determination. (a) analytes, (b) samples, (c) analytical techniques, and (d) types of platforms. The fractions were calculated based on the selected articles.

A variety of transducers have been exploited for biosensing. According to Figure 2c, $85 \%$ of the applications were based on the differential pulse (DPV), square wave (SWV), cyclic (CV), anodic (ASV), or cathodic stripping (CSV), and alternate current voltammetry $(\mathrm{ACV})$, and amperometry (AP), electrochemical impedance spectroscopy (EIS), potentiometry (PT), conductometry (CD), and chrono-amperometry (CA). The development of selective procedures with low detection limits using affordable and simple instrumentation makes bioelectrochemical sensors extremely attractive. Spectrochemical biosensors might require higher costs of equipment acquisition and maintenance such as for surface plasmon resonance (SPR), surface-enhanced reflectance spectrometry (SERS), and infrared reflectance spectrometry (IRS). Nevertheless, inexpensive lab-made photometers and fluorimeters have not been exploited for biosensing. Fluorescence (FL) has been more frequently employed [12,58-62] due to the higher sensitivity and the ease of collecting fluorescence emissions rather than transmitted radiation using solid-phase supports.

The widespread use of electrochemical transducers reflects on the types of material frequently employed as supports of biocompounds. According to Figure 2d, gold (GE) and glassy carbon electrodes (GCE) have been the most employed ones, comprising $61 \%$ of the applications. Their electrical and chemical properties and ease for the adherence of biomolecules and nanoparticles make them unique materials for the construction of biosensors. Glass, platinum, screen-printed (SPE), carbon paste (CPE), carbon film, pencil graphite (PGE), and carbon/epoxy mixture electrodes have also been used for immobilizing biomolecules for the electrochemical sensing of metal ions. Gold platforms were also 
applied for piezoelectric [63] and light scattering [48] measurements. As for other optical detection, glass [64], biopolymers [58], and paper [59] have served as adequate supports for the construction of biosensors.

In general, some common experimental conditions were observed for the use of biosensors. Temperature and $\mathrm{pH}$ are critical parameters in enzymatic reactions, as well as for favoring complexation. As these reactions generally simulate living systems, physiological $\mathrm{pH}$ (between 7.0 and 7.5) and temperature (from 25 to $40{ }^{\circ} \mathrm{C}$ ) were employed in most applications. These conditions also contributed to improve the lifetime of biosensors by avoiding significant changes in the folding of the sensing component somehow. When complexation is the main principle involved, the temperature was generally not controlled. In rare exceptions, an acidic $\mathrm{pH}$ between 1 and 2 was exploited for biosensing [54,65-68]. An alkaline $\mathrm{pH}$ was not evaluated due to the decrease in biochemical responses and to the hydrolysis of metal ions. In time, 2-amino-2-hydroxymethyl-propane-1,3-diol (TRIS) and phosphate solutions were mainly employed as buffers.

The short and long-term stabilities of biosensors are important features. Apart from disposable devices, biosensors lasted from a few determinations up to three months without significant losses of analytical response. Mainly, the conditions of storage, the immobilization strategy, and the number of analyses per day have a direct influence on their lifetime. In most cases, the preservation of the devices was carried out under refrigeration at $4{ }^{\circ} \mathrm{C}$ and preferably immersed in a buffer solution, which enabled their use for more than a workday. In a few cases, biosensors were stored at an ambient temperature and under drying conditions, such as in the determination of Cd(II) $[46,69]$. Alternatively, a mix of reagents can be stocked and used for the daily preparation of the biosensor. In general, these mixtures showed longer lifetimes. Despite the valuable importance of this parameter, many works have not developed a systematic evaluation of the stability of their respective biosensors. This is one of the critical pieces of information that must be explicitly discussed.

Another poorly discussed topic in many articles was the cycles of reusage of the sensors. Most of the works did not make clear if their biosensors were reusable after determinations and if so, the limiting number of replicates that were carried out for that device. In general, reusable biosensors based on a metal complexation with DNA and other biomolecules were submitted to cleanup with EDTA. The removal of the analyte from the biosensor was achieved within 5-30 min, being ready for reuse after rinsing with a buffer solution $[13,53,70,71]$. Rarely has a simple cleaning with a buffer without additional reagents proven to be efficient for recycling. Nevertheless, the regeneration with EDTA must not be taken as a general approach because it might affect the performance of the sensor by removing the metal ion from enzymes, for example. Aminoacids were also employed for the regeneration of biosensors, especially when the bonding with DNA strands was exploited. In this regard, cysteine was employed for the regeneration of sensors for $\mathrm{Hg}$ (II) determination [41,72,73], for the ability to form a more stable complex with the analyte. This simple strategy increased the lifetime of the biosensors up to 15-fold.

\section{Biorecognition Mechanisms and Features}

The mechanism involved in a biosensor response depends on the employed biorecognition system. Despite several biochemical reactions that have been exploited for biosensing metal ions, the bottom line is the ability of analytes and biomolecules to form coordinated adducts. This bonding is generally exploited to adsorb/accumulate metal ions upon the sensor surface or to alter biochemical reactions. The former does not always mimic naturally occurring processes. For example, the determination of Fe(III) was based on its coordination with deferrioxamine [66], which normally does not occur in living organisms. On the other hand, enzymatic reactions and the hybridization of DNA strands were promoted or hindered after the reaction of specific sites of enzymes and nitrogen bases with cations. 


\subsection{Metal Ion Accumulation}

The accumulation of metal ions on the surface of the sensors has been used to enhance analytical responses. Biomolecules or whole cells were generally immobilized or entrapped at the surface of the transducer to promote the approximation of the analyte. The association of this strategy with electrochemical transducers significantly lowered the detection limits, especially when stripping voltammetry was employed for the determination of elements [17,46,47]. The coordination of metal ions with proteins [74], aminoacids [17,75-79], synthetized peptides [70], hormones (melatonine [80] and oxytocin [7]), DNA strands [17,46,81-83], and a neurotransmitter (neurokinin B [38]) were exploited to achieve detection limits as low as $0.80 \mathrm{ag} \mathrm{L}^{-1}$ [81]. The selected articles regarding this mechanism are displayed in Table 1.

Table 1. Selected applications based on an accumulation of ions on the biosensor surface.

\begin{tabular}{|c|c|c|c|c|c|c|c|}
\hline Analyte & Principle & Remarks & Sample & Technique & $\begin{array}{c}\mathrm{DL} \\
\left(\mu \mathrm{g} \mathrm{L}^{-1}\right)\end{array}$ & $\begin{array}{l}\text { Response } \\
\text { Time (min) }\end{array}$ & Ref. \\
\hline \multirow[t]{2}{*}{$\mathrm{Ca}(\mathrm{II})$} & $\begin{array}{l}\text { Bonding with } \\
\text { polymerized melatonin }\end{array}$ & $\begin{array}{l}\text { GCE coated with polymerized } \\
\text { melatonin after electrochemical } \\
\text { deposition }\end{array}$ & $\begin{array}{l}\text { Cerebrospinal } \\
\quad \text { fluid }\end{array}$ & DPV & 18 & NI & [80] \\
\hline & $\begin{array}{l}\text { Bonding with } \\
\text { immobilized tyrosine }\end{array}$ & $\begin{array}{l}\text { Modified FET with amino groups and } \\
\text { crosslink with tyrosinase }\end{array}$ & $\begin{array}{l}\text { Intracellular } \\
\text { fluids }\end{array}$ & $\mathrm{CD}$ & NI & NI & [84] \\
\hline \multirow[t]{3}{*}{$\mathrm{Cd}(\mathrm{II})$} & $\begin{array}{l}\text { Complexation with } \\
\text { aptamer }\end{array}$ & $\begin{array}{l}\text { Aptamer immobilized on GCE } \\
\text { modified with carbon nitride and } \\
\text { reduced graphene oxide. }\end{array}$ & $\begin{array}{l}\text { Tap, natural, and } \\
\text { waste waters }\end{array}$ & ASV & 0.038 & NI & [46] \\
\hline & $\begin{array}{l}\text { Bonding with } \\
\text { immobilized aptamer }\end{array}$ & $\begin{array}{l}\text { Immobilization of aptamer on a GE } \\
\text { modified with a reduced diazonium } \\
\text { salt }\end{array}$ & River waters & EIS & 0.030 & 30 & [85] \\
\hline & $\begin{array}{l}\text { Complexation with } \\
\text { aptamer }\end{array}$ & $\begin{array}{l}\text { Aptamer immobilized on ITO } \\
\text { electrode modified with gold layer }\end{array}$ & Lake waters & PEC & 0.0012 & 60 & [86] \\
\hline \multirow[t]{15}{*}{$\mathrm{Cu}(\mathrm{II})$} & Complexation with BSA & $\begin{array}{l}\text { Immobilization of BSA with } \\
\text { benzophenone mediated using UV } \\
\text { radiation on a SPE }\end{array}$ & Wines & $\mathrm{AP}$ & 173 & 180 & [75] \\
\hline & $\begin{array}{l}\text { Complexation with } \\
\text { neurokinin B }\end{array}$ & $\begin{array}{c}\text { Immobilization of neurokinin B and } \\
\text { ABTS (mediator) on GCE modified } \\
\text { with CNT }\end{array}$ & $\begin{array}{l}\text { Animal plasma } \\
\text { and tissues }\end{array}$ & DPV & 2.5 & NI & [38] \\
\hline & $\begin{array}{l}\text { Complexation with } \\
\text { phytate }\end{array}$ & $\begin{array}{c}\text { Phytic acid and polypirrole nanowires } \\
\text { sealed with } \\
\text { Nafion }{ }^{\circledR} \text { on GCE }\end{array}$ & Wastewater & ASV & 3.3 & 300 & [47] \\
\hline & $\begin{array}{l}\text { Complexation with } \\
\text { neurokinin B }\end{array}$ & $\begin{array}{l}\text { Neurokinin B and ABTS sealed with } \\
\text { polymeric membrane of ionic liquid } \\
\text { on GCE }\end{array}$ & $\begin{array}{c}\text { Animal } \\
\text { cerebrospinal } \\
\text { fluid and tissues }\end{array}$ & DPV & 15 & NI & [87] \\
\hline & $\begin{array}{l}\text { Complexation with } \\
\text { tripeptide }\end{array}$ & $\begin{array}{l}\text { Tripeptide immobilized on } \\
\text { polypirrole and } \mathrm{ZnO} \text { nanoparticles on } \\
\text { ITO electrode. }\end{array}$ & Drinking water & SWV & 3.0 & 11 & [70] \\
\hline & $\begin{array}{l}\text { Complexation with } \\
\text { polymerized } \\
\text { polyphenols }\end{array}$ & $\begin{array}{l}\text { Electropolymerization of luteolin and } \\
\text { kaempferon on GCE }\end{array}$ & NA & DPV & 0.00064 & 60 & [88] \\
\hline & $\begin{array}{l}\text { Preconcentration by } \\
\text { passive biosorption }\end{array}$ & $\begin{array}{l}\text { Addition of lyophilized biomass of } \\
\text { Rhodotorula mucilaginosa to a CPE }\end{array}$ & NA & CSV & NI & 15 & [89] \\
\hline & $\begin{array}{l}\text { Preconcentration by } \\
\text { passive biosorption }\end{array}$ & $\begin{array}{l}\text { Addition of lyophilized biomass of } \\
\text { Tetraselmis chuii to a CPE }\end{array}$ & $\begin{array}{l}\text { Multivitamin } \\
\text { tablets }\end{array}$ & CSV & 0.029 & 30 & [90] \\
\hline & $\begin{array}{l}\text { Complexation with } \\
\text { modified cysteine }\end{array}$ & $\begin{array}{l}\text { Immobilization of modified cysteine } \\
\text { on GCE by APM }\end{array}$ & Animal tissue & $\mathrm{AP}$ & 1.0 & 15 & [91] \\
\hline & $\begin{array}{l}\text { Preconcentration on } \\
\text { GNP modified with } \\
\text { cysteine }\end{array}$ & $\begin{array}{l}\text { Cysteine immobilization on GNP via } \\
\text { thiol groups and electrodeposition on } \\
\text { ITO electrode }\end{array}$ & Tap water & SWV & 0.30 & 12 & [92] \\
\hline & $\begin{array}{l}\text { Complexation with } \\
\text { immobilized glycine }\end{array}$ & $\begin{array}{c}\text { Carbon SPE modified with glycine } \\
\text { using agarose layer }\end{array}$ & Wine & $\mathrm{CV}$ & 40 & 0.5 & [77] \\
\hline & $\begin{array}{l}\text { Complexation with } \\
\text { immobilized synthetic } \\
\text { tripeptide }\end{array}$ & $\begin{array}{l}\text { Deposition of SNP modified with } \\
\text { tripeptide on a GCE coated with } \\
\text { Poly-diallyldimethylammonium }\end{array}$ & $\begin{array}{l}\text { Tap, natural, and } \\
\text { waste waters }\end{array}$ & EIS & 0.54 & 15 & [51] \\
\hline & $\begin{array}{l}\text { Complexation and } \\
\text { quenching of BSA/gold } \\
\text { fluorescence }\end{array}$ & $\begin{array}{l}\text { BSA/gold nanoclusters adsorbed on } \\
\text { paper platform }\end{array}$ & NA & FL & 317 & NI & [59] \\
\hline & $\begin{array}{l}\text { Complexation with } \\
\text { immobilized prion } \\
\text { protein }\end{array}$ & $\begin{array}{l}\text { Protein bonding with adsorbed APTS } \\
\text { on FET silicon gate surface }\end{array}$ & Human serum & PT & 0.63 & 30 & [39] \\
\hline & $\begin{array}{l}\text { Complexation with } \\
\text { immobilized cysteine }\end{array}$ & $\begin{array}{l}\text { Cysteine immobilization on nail } \\
\text { polisher material coated with GNP }\end{array}$ & NA & $\mathrm{CV}$ & 50 & 10 & [76] \\
\hline
\end{tabular}


Table 1. Cont.

\begin{tabular}{|c|c|c|c|c|c|c|c|}
\hline Analyte & Principle & Remarks & Sample & Technique & $\begin{array}{c}\mathrm{DL} \\
\left(\mu \mathrm{g} \mathrm{L}^{-1}\right)\end{array}$ & $\begin{array}{l}\text { Response } \\
\text { Time (min) }\end{array}$ & Ref. \\
\hline & $\begin{array}{l}\text { Complexation with } \\
\text { immobilized synthetic } \\
\text { tripeptide }\end{array}$ & $\begin{array}{l}\text { Immobilized tripeptide } \\
\text { glycine-glycine-histidine on GE. }\end{array}$ & NA & SWV & 6.3 & 15 & [93] \\
\hline & $\begin{array}{l}\text { Complexation with } \\
\text { cysteine }\end{array}$ & $\begin{array}{l}\text { Immobilization of cysteine on } \\
\text { semiconductor modified with GNP }\end{array}$ & NA & LSV & $6.4 \times 10^{-8}$ & 1.5 & [78] \\
\hline & $\begin{array}{l}\text { Complexation with } \\
\text { fluorescent oligopeptide }\end{array}$ & $\begin{array}{l}\text { Oligopeptide immobilized on liquid } \\
\text { crystal surface }\end{array}$ & NA & FL & 6.4 & 180 & [94] \\
\hline & $\begin{array}{l}\text { Complexation with } \\
\text { chitin }\end{array}$ & $\begin{array}{l}\text { Chitin-polyaniline film deposited on } \\
\text { ITO electrode }\end{array}$ & $\begin{array}{l}\text { Ground and } \\
\text { waste waters }\end{array}$ & PT & 13000 & 4 & [95] \\
\hline $\mathrm{Cr}(\mathrm{VI})$ & $\begin{array}{l}\text { Complexation with } \\
\text { melanin followed by a } \\
\text { reduction in the analyte }\end{array}$ & $\begin{array}{l}\text { Melanin adsorbed on SPE coated with } \\
\text { polyvinyl alcohol }\end{array}$ & $\begin{array}{l}\text { Tap and river } \\
\text { waters }\end{array}$ & $\mathrm{AP}$ & 1.6 & 1.5 & [74] \\
\hline $\mathrm{Cr}(\mathrm{VI}), \mathrm{Cr}(\mathrm{III})$ & $\begin{array}{l}\text { Bioaccumulation in } \\
\text { bacterial cells }\end{array}$ & $\begin{array}{l}\text { Drop coating of CPE with a } \\
\text { suspension of Sphingopyxis } \\
\text { acrogoltabida }\end{array}$ & River water & CSV & $\begin{array}{l}\mathrm{Cr}(\mathrm{VI}): 0.052 \\
\mathrm{Cr}(\mathrm{III}): 5.2\end{array}$ & 5 & [6] \\
\hline \multirow[t]{3}{*}{$\mathrm{Fe}(\mathrm{III})$} & $\begin{array}{l}\text { Complexation with } \\
\text { immobilized } \\
\text { deferoxamine }\end{array}$ & $\begin{array}{c}\text { Immobilization of deferoxamine by } \\
\text { APM on gold disk coupled an optical } \\
\text { fiber }\end{array}$ & NA & SPR & 111 & 5 & [65] \\
\hline & $\begin{array}{l}\text { Quenching of } \\
\text { parabactin fluorescence }\end{array}$ & $\begin{array}{l}\text { Silica wall of fluorescence flow cell } \\
\text { coated with parabactin sealed with } \\
\text { sol-gel matrix }\end{array}$ & Seawater & FL & 0.0022 & 10 & {$[61]$} \\
\hline & $\begin{array}{l}\text { Complexation with } \\
\text { immobilized } \\
\text { deferoxamine }\end{array}$ & $\begin{array}{l}\text { Immobilization of deferoxamine by } \\
\qquad \mathrm{APM} \text { on GE }\end{array}$ & $\begin{array}{l}\text { Plants, alloys, } \\
\text { and } \\
\text { pharmaceuticals }\end{array}$ & EIS & 0.0011 & 20 & [66] \\
\hline \multirow[t]{7}{*}{$\mathrm{Hg}$ (II) } & $\begin{array}{l}\text { Bonding with DNA } \\
\text { strands via thymine } \\
\text { base }\end{array}$ & $\begin{array}{l}\text { Immobilization of DNA on PGE } \\
\text { modified with GNP and methionine }\end{array}$ & $\begin{array}{l}\text { Seawaters and } \\
\text { seafood }\end{array}$ & ASV & $8.0 \times 10^{-13}$ & 4 & [81] \\
\hline & $\begin{array}{l}\text { Bonding with DNA } \\
\text { strands }\end{array}$ & $\begin{array}{l}\text { SPE coated with DNA strands bonded } \\
\text { with of GNP }\end{array}$ & $\begin{array}{l}\text { Tap and river } \\
\text { waters }\end{array}$ & SWV & 0.0012 & 80 & [96] \\
\hline & $\begin{array}{l}\text { Complexation with } \\
\text { immobilized } \\
\text { oligonucleotide }\end{array}$ & $\begin{array}{l}\text { Phosphorothioate oligonucleotide } \\
\text { adsorbed on GCE. }\end{array}$ & NA & SWV & 0.0047 & 60 & [97] \\
\hline & $\begin{array}{l}\text { Bonding with DNA } \\
\text { strands }\end{array}$ & $\begin{array}{c}\text { Cysteamine reaction with } \\
\text { thymin-1-ylacetic acid and } \\
\text { immobilization on GCE via APM }\end{array}$ & Tap waters & DPV & 0.0015 & 15 & [98] \\
\hline & $\begin{array}{l}\text { Complexation with } \\
\text { synthetic aptamer }\end{array}$ & $\begin{array}{l}\text { Immobilization of aptamers and } \\
\text { diaminonaphthalene on FET modified } \\
\text { with graphene }\end{array}$ & Mussel digests & $\mathrm{AP}$ & 0.0020 & 0.02 & [99] \\
\hline & $\begin{array}{l}\text { Complexation with } \\
\text { chlorophyll }\end{array}$ & $\begin{array}{l}\text { Chlorophyll entrapped in a mixture of } \\
\text { PVC and NPOE inside a glass disk. }\end{array}$ & NA & PT & 78 & 2 & [100] \\
\hline & $\begin{array}{l}\text { Bonding with } \\
\text { immobilized DNA via } \\
\text { thymine base }\end{array}$ & Immobilization on GE & Milk powder & SWV & 0.00010 & 120 & [101] \\
\hline \multirow[t]{5}{*}{$\mathrm{Pb}(\mathrm{II})$} & $\begin{array}{l}\text { Biosorption by yeast } \\
\text { cells }\end{array}$ & $\begin{array}{l}\text { SPE coated with lyophilized yeast } \\
\text { modified with } \mathrm{Co}_{3} \mathrm{O}_{4}\end{array}$ & $\begin{array}{l}\text { Human blood } \\
\text { and serum }\end{array}$ & SWV & $3.4 \times 10^{-9}$ & 2.5 & [43] \\
\hline & $\begin{array}{l}\text { Complexation with } \\
\text { immobilized aptamer }\end{array}$ & $\begin{array}{c}\text { Immobilization of aptamers on SPE } \\
\text { modified with gold and polypyrrol } \\
\text { nanoparticles }\end{array}$ & $\begin{array}{l}\text { Biological } \\
\text { material and } \\
\text { soils }\end{array}$ & DPV & 0.074 & 30 & [102] \\
\hline & $\begin{array}{l}\text { Complexation with } \\
\text { immobilized DNA } \\
\text { strand }\end{array}$ & $\begin{array}{l}\text { Immobilization of DNA strands on } \\
\text { GCE modified with MOF }\end{array}$ & $\begin{array}{l}\text { Tap waters and } \\
\text { fertilizers }\end{array}$ & EIS & 0.0018 & NI & [82] \\
\hline & $\begin{array}{l}\text { Bonding with } \\
\text { immobilized DNA }\end{array}$ & $\begin{array}{l}\text { Immobilization of DNA on magnetic } \\
\text { particles coated with gold layer and } \\
\text { retention under a GCE with a magnet }\end{array}$ & $\begin{array}{l}\text { Tap and lake } \\
\text { waters, and } \\
\text { sediments }\end{array}$ & DPV & 0.0030 & 5 & [83] \\
\hline & $\begin{array}{l}\text { Complexation with } \\
\text { immobilized cysteine } \\
\text { polymer }\end{array}$ & $\begin{array}{l}\text { Immobilization of cysteine by } \\
\text { electropolymerization on CPE }\end{array}$ & $\begin{array}{l}\text { Natural and } \\
\text { wastewaters }\end{array}$ & EIS & 0.000016 & 4 & [79] \\
\hline $\mathrm{Cu}(\mathrm{II}), \mathrm{Zn}(\mathrm{II})$ & Bonding with oxytocin & $\begin{array}{c}\text { Immobilized oxytocin on GCE by } \\
\text { APM }\end{array}$ & Human serum & EIS & NI & 5 & [7] \\
\hline $\mathrm{Cd}(\mathrm{II}), \mathrm{Pb}(\mathrm{II})$ & $\begin{array}{l}\text { Complexation with } \\
\text { glutathione }\end{array}$ & $\begin{array}{l}\text { Adsorption of glutathione on } \\
\text { magnetic solid entrapped over GCE } \\
\text { surface using a magnet }\end{array}$ & $\begin{array}{l}\text { Sea, Tap, and } \\
\text { mineral waters }\end{array}$ & ASV & $\begin{array}{l}\text { Cd: } 0.17 \\
\mathrm{~Pb}: 0.18\end{array}$ & 3.5 & [17] \\
\hline
\end{tabular}

Abbreviations were displayed on the "list of abbreviations".

Natural extracts were sources of biomolecules for the construction of biosensors. Chlorophyll was obtained from spinach extract before immobilization for the potentiometric determination of $\mathrm{Mg}(\mathrm{II})$ [100]. After the purification of the extract, chlorophyll was mixed with polyvinyl chloride (PVC) and nitrophenyloctylether to yield a plastic membrane that was used to implement the potentiometric ion-selective electrode. Despite the low detection limit ( $78 \mu \mathrm{g} \mathrm{L}^{-1}$ ) and suitable response time (up to $120 \mathrm{~s}$ ), further selectivity refinements must be carried out for the sample application because of $\mathrm{Ca}$ (II) 
interference. Nevertheless, this type of electrode could be employed, e.g., for $\mathrm{Mg}(\mathrm{II})$ and $\mathrm{Ca}$ (II) determination using ion chromatography with potentiometric detection [103].

The accumulation of cations on biosensors can hinder the electroactivity of chemical mediators. The determination of Fe(III) in plants, alloys and pharmaceutical formulations as low as $5.6 \mathrm{ng} \mathrm{L}^{-1}$ using the EIS technique was achieved after the immobilization of Deferrioxamine B on a GE [66]. The complex increased the impedance response due to the constrained electron transfer with the ferrocene/methanol probe.

In the case of optical biosensors, immobilized biomolecules were generally derivatizing reagents that yielded shifts of fluorescence [58,59,61,94], molecular absorption [104], Raman effect by light scattering $[48,105]$, and surface plasmon resonance [64,65]. Optosensors have been exploited to a lesser extent compared to electrochemical ones because of the direct relationship between the instrumentation costs and the performance achieved. However, the possibility of exploring low-cost laboratory devices for photometric and fluorimetric measurements for specific applications may be a future challenge in the field of optical sensors. Determinations at ng $\mathrm{L}^{-1}$ levels based on the complexation of cations were achieved in half of the surveyed works that employed optosensors $[48,61,104,105]$, indicating that strategies for enhancing sensitivity must be exploited.

Lyophilized cells have also been employed to act as pre-concentration probes of biosensors. $\mathrm{Cu}(\mathrm{II})[89,90]$ and $\mathrm{Pb}$ (II) [43] determinations using adsorptive stripping voltammetry were performed with immobilized microalgae and yeasts, which are prone to the construction of biosensors because of their high resistance, low cost, and ready availability. Biosensors based on Rhodotorula mucilaginosa and Tetraselmis chuii were used for $\mathrm{Cu}(\mathrm{II})$ detection as low as $29 \mathrm{ng} \mathrm{L}^{-1}$. The former was suitable for this application because of its well-known $\mathrm{Cu}(\mathrm{II})$ bioaccumulation [89]. On the other hand, the biosorption of the analyte by Tetraselmis chuii [90] and other microalgae is not well understood, but it is probably promoted by biopolymer components of their cell walls. Besides the natural accumulation of cations, modifications of cell walls were also explored. The detection of $\mathrm{Pb}$ (II) was estimated at $3.4 \times 10^{-6} \mathrm{ng} \mathrm{L}^{-1}$ by using a biosensor with immobilized yeast cells coated with $\mathrm{Co}_{3} \mathrm{O}_{4}$ and $\mathrm{Au}$ nanoparticles, which were responsible for the adsorption of the analyte [43].

\subsection{Catalysis and Inhibition}

Biosensors for metal ions have also been constructed based on rate changes in particular enzymatic activity due to the bonding of cations or due to participation in the intermediate steps of the process. Biosensors based on metabolic and enzymatic reactions are presented in Table 2.

Table 2. Selected applications of biosensors based on catalysis and inhibition.

\begin{tabular}{|c|c|c|c|c|c|c|c|}
\hline Analyte & Principle & Remarks & Sample & Technique & $\begin{array}{c}\mathrm{DL} \\
\left(\mu \mathrm{g} \mathrm{L}^{-1}\right)\end{array}$ & $\begin{array}{l}\text { Response } \\
\text { Time (min) }\end{array}$ & Ref. \\
\hline $\mathrm{Ca}(\mathrm{II})$ & $\begin{array}{l}\text { Enhancement of } \\
\text { catalase activity } \\
\text { increased } \mathrm{O}_{2} \text { generation }\end{array}$ & $\begin{array}{l}\text { Gold cathode of a commercial } \\
\text { oximeter coated with a gelatin layer } \\
\text { to entrap catalase }\end{array}$ & Milk & $\mathrm{AP}$ & 40 & 60 & [106] \\
\hline \multirow[t]{6}{*}{$\mathrm{Cd}(\mathrm{II})$} & $\begin{array}{l}\text { Inhibition of urease } \\
\text { activity }\end{array}$ & $\begin{array}{l}\text { Modification of urease with SPDP } \\
\text { on GE }\end{array}$ & NA & SPR & NI & 30 & [64] \\
\hline & $\begin{array}{l}\text { Inhibition of glucose } \\
\text { oxidase activity }\end{array}$ & $\begin{array}{l}\text { Immobilization of enzyme onto } \\
\text { PGE modified with carboxylated } \\
\text { CNT }\end{array}$ & NI & DPV & 1600 & $<1$ & [69] \\
\hline & $\begin{array}{l}\text { Inhibition of HRP } \\
\text { activity }\end{array}$ & $\begin{array}{l}\text { HRP linked to maize tassel/CNT } \\
\text { composite and sealed with Nafion }{ }^{\circledR} \\
\text { on GCE }\end{array}$ & Natural waters & $\mathrm{CV}$ & 0.51 & 20 & [107] \\
\hline & $\begin{array}{l}\text { Inhibition of } \\
\text { photosynthetic } \mathrm{O}_{2} \\
\text { release }\end{array}$ & $\begin{array}{c}\text { Anabaena torulosa sealed on the } \\
\text { cathode of oximeter with } \\
\text { poly(2-hydroxyl ethyl } \\
\text { methacrylate) }\end{array}$ & Wastewaters & $\mathrm{AP}$ & NI & $<5$ & [49] \\
\hline & $\begin{array}{l}\text { Inhibition of } \\
\text { fluorescence of green } \\
\text { fluorescent protein }\end{array}$ & $\begin{array}{c}\text { Encapsulation of the protein using a } \\
\text { tetramethoxysilane sol-gel on } \\
\text { optical fibers }\end{array}$ & NA & FL & 32 & $\mathrm{NI}$ & [58] \\
\hline & $\begin{array}{l}\text { Inhibition of organic } \\
\text { matter decomposition }\end{array}$ & $\begin{array}{c}\text { MFC with Shewanella Putrefaciens } \\
\text { biofilm. }\end{array}$ & Wastewaters & PT & 40 & $<1$ & [50] \\
\hline
\end{tabular}


Table 2. Cont.

\begin{tabular}{|c|c|c|c|c|c|c|c|}
\hline Analyte & Principle & Remarks & Sample & Technique & $\begin{array}{c}\mathrm{DL} \\
\left(\mu \mathrm{g} \mathrm{L}^{-1}\right)\end{array}$ & $\begin{array}{l}\text { Response } \\
\text { Time (min) }\end{array}$ & Ref. \\
\hline & $\begin{array}{l}\text { Inhibition of HRP } \\
\text { activity }\end{array}$ & $\begin{array}{l}\text { Enzyme immobilization on a } \\
\text { porous } \mathrm{SiO}_{2} \text { surface modified with } \\
\text { APTS }\end{array}$ & $\begin{array}{l}\text { Tap, drain and } \\
\text { irrigation waters }\end{array}$ & IRS & 80 & 40 & [108] \\
\hline & $\begin{array}{l}\text { Fluorescence quenching } \\
\text { of genetically modified } \\
\text { E. coli }\end{array}$ & $\begin{array}{l}\text { Modified E. coli encapsulated in } \\
\text { polyacrylamide hydrogel platform }\end{array}$ & NA & FL & 317 & 30 & {$[60]$} \\
\hline & $\begin{array}{c}\text { Alteration of S. cerevisiae } \\
\text { metabolism }\end{array}$ & $\begin{array}{l}\text { Yeast sealed in calcium alginate } \\
\text { beads }\end{array}$ & Well water & DI & 13 & 15 & [109] \\
\hline & $\begin{array}{l}\text { Inhibition of urease } \\
\text { activity }\end{array}$ & $\begin{array}{l}\text { Immobilization of urease on a } \\
\text { silicon surface modified with } \\
\text { graphene oxide and gold layers }\end{array}$ & $\begin{array}{l}\text { Rain and river } \\
\text { waters }\end{array}$ & AFM & 0.018 & 15 & [110] \\
\hline & $\begin{array}{c}\text { Inhibition of } \\
\text { phosphatase activity }\end{array}$ & $\begin{array}{l}\text { Immobilization of phosphatase on } \\
\text { antimony tin oxide nanoparticles } \\
\text { deposited on a paper support }\end{array}$ & Seafood & MAS & 0.006 & NI & [111] \\
\hline \multirow[t]{3}{*}{$\mathrm{Cr}(\mathrm{VI})$} & $\begin{array}{l}\text { Potential drop of MFC } \\
\text { due to anthropic side } \\
\text { reaction with } \\
\text { Ochrobactrum }\end{array}$ & MFC with a polymeric biofilm & $\begin{array}{c}\text { Drinking, } \\
\text { natural and } \\
\text { waste waters }\end{array}$ & PT & 12 & 45 & [52] \\
\hline & $\begin{array}{l}\text { Inhibition of catalytic } \\
\text { activity of urease }\end{array}$ & $\begin{array}{l}\text { Crude extract containing urease } \\
\text { sealed with tetramethyl } \\
\text { orthosilicate sol-gel on GE }\end{array}$ & Wastewater & $\mathrm{AP}$ & NI & 25 & [53] \\
\hline & $\begin{array}{l}\text { Inhibition of glucose } \\
\text { oxidase activity }\end{array}$ & $\begin{array}{l}\text { Entrapment of glucose oxidase with } \\
\text { chitosan on paper device }\end{array}$ & NA & $\mathrm{AP}$ & 50 & 5 & [112] \\
\hline $\mathrm{Cr}(\mathrm{III})$ & $\begin{array}{l}\text { Inhibition of catalytic } \\
\text { activity of HRP }\end{array}$ & $\begin{array}{l}\text { Crosslinked HRP/BSA with } \\
\text { poly(neutral red) layer on carbon } \\
\text { film electrode. }\end{array}$ & NA & $\mathrm{AP}$ & 1.5 & 1.3 & [113] \\
\hline $\begin{array}{l}\mathrm{Cr}(\mathrm{III}), \\
\mathrm{Cr}(\mathrm{VI})\end{array}$ & $\begin{array}{l}\text { Inhibition of tyrosinase } \\
\text { and glucose oxidase } \\
\text { activities }\end{array}$ & $\begin{array}{l}\text { Tyrosinase, glucose oxidase, and } \\
\text { mediators immobilized on separate } \\
\text { SPE }\end{array}$ & $\begin{array}{l}\text { Tap and waste } \\
\text { waters }\end{array}$ & CA & $\begin{array}{l}\mathrm{Cr}(\mathrm{III}): 104 \\
\mathrm{Cr}(\mathrm{VI}): 4.7\end{array}$ & 17 & [5] \\
\hline $\mathrm{Cu}(\mathrm{II})$ & $\begin{array}{l}\text { Activation of tyrosinase } \\
\text { and oxidation of } \\
\text { dopamine }\end{array}$ & $\begin{array}{l}\text { Entrapment of enzyme on } \\
\text { polyacrylamide sol-gel after } \\
\text { removal of prosthetic } \mathrm{Cu}(\mathrm{II}) \text { ions }\end{array}$ & $\begin{array}{l}\text { Drinking water } \\
\text { and milk }\end{array}$ & MAS & 0.010 & 15 & [114] \\
\hline $\mathrm{Fe}(\mathrm{II}), \mathrm{Fe}(\mathrm{III})$ & $\begin{array}{l}\text { Fe(II) oxidation } \\
\text { catalyzed by Thiobacillus } \\
\text { ferrooxidans }\end{array}$ & $\begin{array}{l}\text { Thiobacillus ferrooxidans/jarosite } \\
\text { suspension adsorbed on cellulose } \\
\text { and fixed on the cathode of an } \\
\text { oximeter using a membrane }\end{array}$ & $\begin{array}{l}\text { Mine waste and } \\
\text { mineral extracts }\end{array}$ & $\mathrm{AP}$ & 3300 & $<5$ & {$[54]$} \\
\hline $\mathrm{Fe}(\mathrm{II}), \mathrm{Cr}(\mathrm{VI})$ & $\begin{array}{l}\text { Biocatalytic oxidation } \\
\text { by Leptospirillum } \\
\text { ferrooxidans }\end{array}$ & $\begin{array}{l}\text { Leptospirillum ferrooxidans cells } \\
\text { adsorbed on cellulose assembled on } \\
\text { cathode of oximeter sealed by a } \\
\text { plastic membrane }\end{array}$ & NA & $\mathrm{AP}$ & $\begin{array}{l}\text { Fe: } 134 \\
\text { Cr: } 22\end{array}$ & 0.3 & [67] \\
\hline $\mathrm{Fe}(\mathrm{II})$ & $\begin{array}{l}\text { Biocatalytic oxidation } \\
\text { by Acidithiobacillus } \\
\text { ferrooxidans }\end{array}$ & $\begin{array}{l}\text { Cathode of oximeter coated with } \\
\text { Acidithiobacillus ferrooxidans sealed } \\
\text { by cellulose membrane }\end{array}$ & NA & $\mathrm{AP}$ & 50 & 1.4 & {$[68]$} \\
\hline \multirow[t]{2}{*}{$\mathrm{Hg}(\mathrm{II})$} & $\begin{array}{l}\text { Inhibition of catalase } \\
\text { activity }\end{array}$ & $\begin{array}{l}\text { Catalase/BSA immobilized on GCE } \\
\text { via crosslink with glutaraldehyde }\end{array}$ & $\begin{array}{l}\text { Drinking and } \\
\text { natural waters }\end{array}$ & $\mathrm{AP}$ & 0.0036 & 10 & [115] \\
\hline & $\begin{array}{l}\text { Inhibition of Chlorella sp. } \\
\text { metabolism }\end{array}$ & Adsorption of Chlorella sp. on GCE & Wastewaters & $\mathrm{AP}$ & 0.014 & 5 & [55] \\
\hline $\mathrm{Mn}(\mathrm{II})$ & $\begin{array}{l}\text { Enhancement of HRP } \\
\text { activity }\end{array}$ & Mixing of HRP with carbon paste & NA & $\mathrm{AP}$ & 28 & 1 & [116] \\
\hline $\mathrm{Ni}(\mathrm{II})$ & $\begin{array}{l}\text { Inhibition of Bacillus } \\
\text { sphaericus metabolism }\end{array}$ & $\begin{array}{l}\text { Adsorption of Bacillus sphaericus } \\
\text { onto cellulose membrane followed } \\
\text { by fixation on potentiometric } \\
\text { electrode }\end{array}$ & $\begin{array}{l}\text { Wastewaters and } \\
\text { food digests }\end{array}$ & PT & 0.0018 & 1.5 & [56] \\
\hline $\mathrm{Pb}(\mathrm{II})$ & $\begin{array}{l}\text { Inhibition of choline } \\
\text { oxidase }\end{array}$ & $\begin{array}{l}\text { Immobilization of choline oxidase } \\
\text { on GCE modified with CNT }\end{array}$ & Tap waters & $\mathrm{AP}$ & 0.0083 & 5 & [117] \\
\hline $\begin{array}{l}\mathrm{Cd}(\mathrm{II}), \mathrm{Co}(\mathrm{II}) \\
\mathrm{Cu}(\mathrm{II}), \mathrm{Ni}(\mathrm{II})\end{array}$ & $\begin{array}{l}\text { Inhibition of glucose } \\
\text { oxidase activity }\end{array}$ & $\begin{array}{c}\text { Carbon film electrodes modified } \\
\text { with Cu or Co hexacyanoferrate } \\
\text { and dip-coated with glucose } \\
\text { oxidase. }\end{array}$ & NA & EIS & $\begin{array}{l}\text { Cd:135 } \\
\text { Co:53 } \\
\text { Cu:13 } \\
\text { Ni:282 }\end{array}$ & 5 & [8] \\
\hline $\begin{array}{l}\mathrm{Cu}(\mathrm{II}), \mathrm{Pb}(\mathrm{II}) \\
\quad \mathrm{Cd}(\mathrm{II})\end{array}$ & $\begin{array}{l}\text { Hindrance of } \\
\text { metabolism of Anabaena } \\
\text { torulosa }\end{array}$ & $\begin{array}{l}\text { Adsorption of whole cells on } \\
\text { cellulose membrane after filtration. }\end{array}$ & NA & EIS & $\begin{array}{l}\text { Cd: } 0.027 \\
\text { Cu: } 1.2 \\
\mathrm{~Pb}: 0.10\end{array}$ & 60 & [12] \\
\hline $\begin{array}{l}\mathrm{Cd}(\mathrm{II}), \mathrm{Cu}(\mathrm{II}) \\
\mathrm{Hg}(\mathrm{II}), \mathrm{Pb}(\mathrm{II})\end{array}$ & $\begin{array}{l}\text { Inhibition of glucose } \\
\text { oxidase activity }\end{array}$ & $\begin{array}{l}\text { Electrodeposition of } \\
\text { polypyrrole/glucose oxidase } \\
\text { mixture on Pt electrode. }\end{array}$ & Tap water & $\mathrm{AP}$ & $\begin{array}{l}\text { Cd: } 450 \\
\text { Cu: } 95 \\
\mathrm{Hg}: 96 \\
\mathrm{~Pb}: 332\end{array}$ & 0.3 & [13] \\
\hline $\begin{array}{l}\mathrm{Cd}(\mathrm{II}), \mathrm{Cu}(\mathrm{II}) \\
\quad \mathrm{Pb}(\mathrm{II})\end{array}$ & $\begin{array}{l}\text { Inhibition of urease } \\
\text { activity }\end{array}$ & $\begin{array}{l}\text { Immobilization of urease SPE } \\
\text { sealed with tetramethoxysilicate } \\
\text { sol-gel }\end{array}$ & NA & $\mathrm{CD}$ & NI & 10 & [14] \\
\hline
\end{tabular}


Table 2. Cont.

\begin{tabular}{|c|c|c|c|c|c|c|c|}
\hline Analyte & Principle & Remarks & Sample & Technique & $\begin{array}{c}\mathrm{DL} \\
\left(\mu \mathrm{g} \mathrm{L^{-1 }}\right)\end{array}$ & $\begin{array}{l}\text { Response } \\
\text { Time (min) }\end{array}$ & Ref. \\
\hline $\begin{array}{c}\mathrm{Cd}(\mathrm{II}), \mathrm{Co}(\mathrm{II}) \\
\mathrm{Cu}(\mathrm{II})\end{array}$ & $\begin{array}{l}\text { Inhibition of glucose } \\
\text { oxidase activity }\end{array}$ & $\begin{array}{c}\text { Glucose oxidase immobilized on } \\
\text { carbon film electrode coated with } \\
\text { cobalt hexacyanoferrate }(\mathrm{CH}) \text { or } \\
\text { poly-neutral red (NR) }\end{array}$ & Tap water & $\mathrm{AP}$ & $\begin{array}{c}\text { Cd:34 (CH), } \\
888(\mathrm{NR}) ; \\
\text { Co: } 100(\mathrm{CH}), \\
1100(\mathrm{NR}) ; \\
\text { Cu: } 5.7(\mathrm{CH}), \\
76(\mathrm{NR})\end{array}$ & NI & [15] \\
\hline $\begin{array}{l}\mathrm{Cd}(\mathrm{II}), \mathrm{Hg}(\mathrm{II}) \\
\mathrm{Pb}(\mathrm{II})\end{array}$ & $\begin{array}{l}\text { Inhibition of peroxidase } \\
\text { activity }\end{array}$ & $\begin{array}{c}\text { Electrodeposition of HRP on Pt disk } \\
\text { coated with polyaniline and } \\
\text { copolymer } \\
\text { poly }\left(2,2^{\prime} \text {-dithiodianiline }\right)\end{array}$ & $\begin{array}{c}\text { Tap and river } \\
\text { waters }\end{array}$ & $\mathrm{AP}$ & $\begin{array}{l}\text { Cd: } 8.0 \times 10^{-4} \\
\text { Hg: } 7.9 \times 10^{-4} \\
\text { Pb: } 9.4 \times 10^{-4}\end{array}$ & $\mathrm{NI}$ & [16] \\
\hline $\begin{array}{l}\mathrm{Cd}(\mathrm{II}), \mathrm{Cu}(\mathrm{II}) \\
\mathrm{Hg}(\mathrm{II}), \mathrm{Pb}(\mathrm{II})\end{array}$ & $\begin{array}{l}\text { Inhibition of glucose } \\
\text { oxidase activity }\end{array}$ & $\begin{array}{c}\text { Electrodeposition of a } \\
\text { polypyrrole/glucose oxidase film } \\
\text { on Pt disk }\end{array}$ & Tap water & PT & NI & 1.6 & [18] \\
\hline $\mathrm{Cu}(\mathrm{II}), \mathrm{Pb}(\mathrm{II})$ & $\begin{array}{l}\text { Inhibition of peroxidase } \\
\text { activity }\end{array}$ & $\begin{array}{l}\text { Immobilized HRP onto maize } \\
\text { tassel/CNT composite sealed by } \\
\text { Nafion }{ }^{\circledR} \text { on GCE }\end{array}$ & Tap water & $\mathrm{AP}$ & $\begin{array}{l}\mathrm{Cu}: 4.2 \\
\mathrm{~Pb}: 2.5\end{array}$ & 20 & [19] \\
\hline $\mathrm{Hg}$ (II), Pb(II) & $\begin{array}{l}\text { Inhibition of urease } \\
\text { activity }\end{array}$ & $\begin{array}{l}\text { Urease sealed with Nafion }{ }^{\circledR} \text { on } \\
\text { alumina coated with } \\
\text { Au/polyaniline }\end{array}$ & NA & $\mathrm{AP}$ & $\begin{array}{l}\text { Hg: } 10 \\
\text { Pb: } 100\end{array}$ & NI & [10] \\
\hline $\begin{array}{l}\mathrm{Hg}(\mathrm{II}), \mathrm{Cd}(\mathrm{II}), \\
\mathrm{Pb}(\mathrm{II}), \mathrm{Cr}(\mathrm{VI})\end{array}$ & $\begin{array}{l}\text { Inhibition of glucose } \\
\text { oxidase }\end{array}$ & $\begin{array}{l}\text { Glucose oxidase and brilliant green } \\
\text { polymer immobilized on GCE } \\
\text { modified with CNT/chitosan }\end{array}$ & Milk & $\mathrm{AP}$ & $\begin{array}{l}\text { Hg: } 0.46 \\
\text { Cd: } 0.20 \\
\text { Pb: } 0.50 \\
\text { Cr: } 0.12\end{array}$ & $\mathrm{NI}$ & [11] \\
\hline
\end{tabular}

Abbreviations were displayed on the "list of abbreviations".

The spectrophotometric detection of $\mathrm{Cu}$ (II) in drinking water and milk [114] was carried out after the immobilization of tyrosinase apoenzyme on polyacrylamide solgel. Extracts from Agaricus bisporus were purified and treated with EDTA to remove the prosthetic $\mathrm{Cu}(\mathrm{II})$ ions from the quaternary structure of the enzyme before immobilization. In this way, the enzyme was active only in the presence of the analyte. Spectral shifts were observed due to the catalyzed conversion of dopamine into dopachrome, which showed an absorption maximum at $475 \mathrm{~nm}$. As the substrate was also immobilized with the enzyme, spectrophotometric measurements were carried out directly on the solid phase, which contributed to a detection limit estimated at $63 \mathrm{ng} \mathrm{L}^{-1}$ for $\mathrm{Cu}(\mathrm{II})$.

Full-enzyme biosensors are less tedious to implement but usually raise selectivity concerns. They are generally based on the effect of the analyte on an enzymatic reaction. Enhancement of the immobilized catalase, for instance, was exploited for the determination of $\mathrm{Ca}$ (II) in milk samples [106] by mimicking the enzyme actuation in plant cells. The evolution of oxygen originated from the decomposition of $\mathrm{H}_{2} \mathrm{O}_{2}$ increased the amperometric signal due to the activation of catalase by $\mathrm{Ca}(\mathrm{II})$. In this way, it was possible to quantify the analyte from 40 to $400 \mathrm{mg} \mathrm{L}^{-1}$ with a common oximeter by coating the gold cathode with a PTFE membrane embedded with a gelatin/enzyme mixture. Nonetheless, high concentrations of concomitants such as $\mathrm{Mg}$ (II) must be carefully considered to avoid inaccuracy. Another example regards Mn(II) determination based on the enhanced activity of the horseradish peroxidase (HPR) in the presence of $\mathrm{O}_{2}$ and a 1,2-naphtoquinone mediator [116]. In the presence of the analyte, the reduction of the mediator was enhanced after oxidation by the HPR. Despite the demonstrated potential, further studies are required for this biosensor to improve selectivity to pave the way to application in real samples.

The inhibition of enzymatic activity was generally based on the affinity of analytes for sites of the enzyme (sulfhydryl group of cysteine) and replacement of the hydrogen atoms by making a covalent bond with sulphur. The consequent conformational shift of the enzyme hindered its affinity for the substrate [118]. Meanwhile, electrochemical transducers have been mainly used to follow up the consumption of substrates with several approaches. The inhibition of the catalytic decomposition of $\mathrm{H}_{2} \mathrm{O}_{2}$ on the electrode surface due to the activity of catalase [115] or HRP $[19,107,113]$ was successfully applied for the determination of $\mathrm{Hg}(\mathrm{II}), \mathrm{Cd}(\mathrm{II}), \mathrm{Cu}(\mathrm{II})$, and $\mathrm{Pb}(\mathrm{II})$. The response to the substrate increased 
with the concentration of the analytes because less $\mathrm{H}_{2} \mathrm{O}_{2}$ was decomposed due to lower enzymatic activity.

Chemical mediators were employed in the sample solution [69] or immobilized on the same platform of the biosensing system $[8,13,15,18]$. The latter strategy is advantageous because it minimizes reagent consumption and the number of steps for analysis. Additionally, the detection limits are lowered because the immobilization facilitates the charge transfer to the electroactive sites of enzymes, such as those reported for sensors with immobilized polyaniline [16] and poly(neutral red) [113]. The response due to the electrochemical regeneration of these mediators yielded signal outputs that were up to 2.5-fold higher than bare electrodes. The incorporation of glucose oxidase on the platform coated with polypyrrole for Cd(II) determination [13] yielded a detection limit of $450 \mathrm{mg} \mathrm{L}^{-1}$, which was 3.5-fold lower than a proposed similar procedure using the same mediator and enzyme in the solution. In this case, the mediator was essential for the electrochemical transduction because the substrate and the products of the enzymatic reaction were electrochemically inactive.

The deposition of the oxidized substrate after the enzymatic reaction was exploited during the development of an optical biosensing platform. The determination of $\mathrm{Cu}$ (II) in natural waters by IRS was based on the catalyzed oxidation of 4-chloro-1-naphtol (4-CN) by immobilized HRP [108]. This process led to the deposition of solid 4-chloro-1-naphton (4-CNP) on the optode, thus altering the infrared spectrum of the support. Therefore, the presence of $\mathrm{Cu}$ (II) ions hindered the formation of 4-CNP because of the inactivation of the enzyme. The estimated detection limit $\left(80 \mu \mathrm{g} \mathrm{L}^{-1}\right)$ was not as low as the ones obtained using electroanalytical techniques, but it was suitable for $\mathrm{Cu}$ (II) determination in waters.

The inhibitory effect of urease was also exploited for toxic metals detection using an unusual strategy. As the enzyme and polyaniline were immobilized on a GE with Nafion ${ }^{\circledR}$ [10], after the enzymatic decomposition of urea, the ammonium ions formed a tertiary complex by bonding with the amino groups from polyaniline and the sulphone groups from Nafion ${ }^{\circledR}$. In the presence of $\mathrm{Hg}$ (II) and $\mathrm{Pb}$ (II), the enzymatic reaction was inhibited, which avoided the formation of the tertiary complex and altered the profile of cyclic voltammograms.

The inhibition of naturally occurring enzymatic reactions of whole cells has also been exploited for analytical purposes. The determinations of $\mathrm{Hg}$ (II) [55] and $\mathrm{Ni}$ (II) [56] were based on hindering the activity of phosphatase (in Chlorella sp.) and urease (in Bacillus sphaericus), respectively. The low cost of commercially available enzymes makes the use of a living cells culture unnecessary for sensors based on the same monitoring of substrates [111,119] and products [56]. Nevertheless, for enzymes in which extraction procedures are laborious and generate high amounts of waste, the use of whole cells can pave the way for simpler and cleaner approaches.

Some biochemical processes, such as complex metabolic reactions, are hard to mimic with synthetic molecules, thus the use of whole cells comes to hand in these situations. The quantification of metal cations was achieved using the inhibition of the metabolism of fluorescent micro-organisms $[12,60,109]$. The quenching of the fluorescence of genetically modified Escherichia coli [60,109] and yeasts [109] was exploited for Cu II) determinations. On the other hand, the fluorescence of immobilized microalgae cells was enhanced in the presence of $\mathrm{Cu}(\mathrm{II}), \mathrm{Cd}(\mathrm{II})$ and $\mathrm{Pb}$ (II) [12] because of the inhibition of photosynthetic electron transport pathways. Therefore, the accumulated energy was released as electromagnetic radiation. Despite the low selectivity and the need for detailed accuracy studies, these approaches are suitable for the toxicity evaluation of waters.

The inhibitory effects on metabolic pathways have also been applied to determination of metal cations with microbial fuel cells (MFC) [50,52] by hindering the decomposition of organic matter due to competitive reactions and, thus, affecting the generation of electrical energy. Shewanella putrefaciens and Ochrobacterium anthropic biofilms were used to coat the anode of MFC for $\mathrm{Cu}(\mathrm{II})$ [50] and $\mathrm{Cr}(\mathrm{VI})$ [52] detection. In the former, despite the occurrence of side reactions in the presence of the cation, there was evidence that the lithotrophic 
behavior of Schiwanella putrefaciens and $\mathrm{Cu}(\mathrm{II})$ adsorption on the anode also contributed to the analytical response. Due to the portability and simplicity of MFC, these devices are suitable for an in situ evaluation of toxicity of industrial wastewaters. However, the biofilm must be resistant enough to overcome aggressive media, such as a high salinity and a low temperature. Other approaches have also been proposed for the detection of metal ions in environmental samples with MFC, but a detailed evaluation of the analytical features was neglected, thus allowing qualitative applications [120-123].

The acceleration of metabolic reactions was exploited for the determination and speciation analysis of Fe with Thiobacillus ferooxidans [54], Leptospirillium ferrooxidans [67], and Acidithiobacillus ferrooxidans [68] by monitoring the increase in $\mathrm{O}_{2}$ consumption. These microorganisms are resistant to acidic media, which allowed direct determinations of $\mathrm{Fe}$ in acidic samples, such as mine waste and mineral extracts [54]. Additionally, a rare behavior was shown by simply participating in a direct reaction involving the metal cation without the need for laborious electrode modifications or the use of mediators. Additionally, the determination of $\mathrm{Cu}$ (II) was carried out in waters as low as $13 \mu \mathrm{g} \mathrm{L}^{-1}$ by an optical sensor based on the immobilization of genetically modified Saccharomyces cerevisiae cells [109]. The presence of the cation induced the production of $5^{\prime}$-phosphoribosylaminoimidazole in the purine synthesis pathway that was oxidized and accumulated due to oxidative stress, and which gives the cells a red color.

\subsection{Affinity}

Selective interactions of biorecognition systems have been used for metal ions biosensing (as displayed in Table 3). An antigen-based sensor was constructed for the determination of $\mathrm{Hg}(\mathrm{II})$ in cosmetics by exploiting a competitive complexation. It consisted of methylmercury bonded to ovalbumin firstly adsorbed on GCE. The subsequent reaction with a monoclonal antibody labeled with quantum dots yielded an electrochemiluminescent (ELC) blank signal [124]. In the presence of the analyte, a competitive reaction occurred, which kept the antibodies tagged with quantum dots away from the GCE, thus decreasing the ELC signal.

Table 3. Selected applications of biosensors based on affinity.

\begin{tabular}{|c|c|c|c|c|c|c|c|}
\hline Analyte & Principle & Remarks & Sample & Technique & $\begin{array}{c}\mathrm{DL} \\
\left(\mu \mathrm{g} \mathrm{L}^{-1}\right)\end{array}$ & $\begin{array}{l}\text { Response } \\
\text { Time (min) }\end{array}$ & Ref. \\
\hline $\mathrm{Ca}(\mathrm{II})$ & $\begin{array}{l}\text { Cleavage of immobilized } \\
\text { DNAzyme }\end{array}$ & $\begin{array}{l}\text { Immobilization of } \\
\text { DNAzyme on a FET } \\
\text { modified with CNT }\end{array}$ & Milk & LSV & 220 & 15 & [125] \\
\hline \multirow[t]{4}{*}{$\mathrm{Cd}(\mathrm{II})$} & $\begin{array}{l}\text { Cleavage of DNA followed } \\
\text { by hybridization with a } \\
\text { single strand labeled with } \\
\text { EG }\end{array}$ & $\begin{array}{l}\text { Electrochemical deposition } \\
\text { of double stranded DNA on } \\
\text { CPE }\end{array}$ & $\begin{array}{l}\text { Tap and sea } \\
\text { waters }\end{array}$ & $\mathrm{AP}$ & $1.0 \times 10^{-5}$ & $\mathrm{NI}$ & [126] \\
\hline & $\begin{array}{c}\text { Complexation with single } \\
\text { stranded DNA labeled with } \\
\text { MB }\end{array}$ & $\begin{array}{l}\text { Dip coating of GE with } \\
\text { thiolated DNA }\end{array}$ & NA & $\mathrm{CV}$ & 0.30 & 15 & [127] \\
\hline & $\begin{array}{l}\text { Competition with EG by } \\
\text { immobilized double } \\
\text { stranded DNA }\end{array}$ & $\begin{array}{l}\text { DNA immobilization on a } \\
\text { GCE modified with CNT }\end{array}$ & NA & DPV & 0.22 & 10 & [128] \\
\hline & $\begin{array}{l}\text { Cleavage of immobilized } \\
\text { DNAzyme }\end{array}$ & $\begin{array}{l}\text { Immobilization of } \\
\text { DNAzyme on a FET } \\
\text { modified with CNT }\end{array}$ & Foods & LSV & 0.0038 & 5 & [129] \\
\hline \multirow[t]{4}{*}{$\mathrm{Cu}(\mathrm{II})$} & $\begin{array}{l}\text { Bonding with immobilized } \\
\text { DNA followed by poisoning } \\
\text { of the electrode with } \\
\text { dehydroascorbic acid }\end{array}$ & $\begin{array}{l}\text { Immobilization of DNA } \\
\text { modified with biotin on a } \\
\text { carbon-avidin epoxy resin }\end{array}$ & NA & EIS & 400 & 30 & [130] \\
\hline & $\begin{array}{c}\text { Bonding with immobilized } \\
\text { DNA strand labeled with } \\
\text { MOF }\end{array}$ & $\begin{array}{l}\text { Immobilization of DNA on } \\
\text { GNP electrodeposited on } \\
\text { ITO electrode }\end{array}$ & $\begin{array}{l}\text { Tap and natural } \\
\text { waters, and soils }\end{array}$ & DPV & 0.029 & $80 \mathrm{~min}$ & [131] \\
\hline & $\begin{array}{l}\text { Spectral shift of polyaniline } \\
\text { platform due complexation } \\
\text { with immunoglobulin }\end{array}$ & $\begin{array}{l}\text { Immobilization of denatured } \\
\text { immunoglobulin on optical } \\
\text { fiber coated with polvaniline }\end{array}$ & $\begin{array}{l}\text { Natural waters, } \\
\text { soils, and blood }\end{array}$ & MAS & 0.063 & 25 & [104] \\
\hline & $\begin{array}{l}\text { Hybridization of } \\
\text { immobilized DNA strand } \\
\text { with aptamer labeled with } \\
\text { glucose oxidase }\end{array}$ & $\begin{array}{l}\text { Immobilization of DNA } \\
\text { strands on a GCE modified } \\
\text { with 6-mercaptohexanol and } \\
\text { Prussian blue (mediator) }\end{array}$ & Natural waters & DPV & $6.3 \times 10^{-12}$ & 30 & [132] \\
\hline
\end{tabular}


Table 3. Cont.

\begin{tabular}{|c|c|c|c|c|c|c|c|}
\hline Analyte & Principle & Remarks & Sample & Technique & $\begin{array}{c}\mathrm{DL} \\
\left(\mu \mathrm{g} \mathrm{L}^{-1}\right)\end{array}$ & $\begin{array}{l}\text { Response } \\
\text { Time (min) }\end{array}$ & Ref. \\
\hline & $\begin{array}{c}\text { Cleavage of immobilized } \\
\text { DNA }\end{array}$ & $\begin{array}{c}\text { Immobilization of thiolated } \\
\text { DNA strands on CGE } \\
\text { modified with GNP }\end{array}$ & Natural waters & EIS & 0.0046 & 50 & [133] \\
\hline & $\begin{array}{l}\text { Bonding and conformation } \\
\text { shift of immobilized DNA } \\
\text { labeled with MB }\end{array}$ & $\begin{array}{l}\text { Immobilized thiolated DNA } \\
\text { on GE. }\end{array}$ & Tap water & SWV & 0.078 & 100 & [134] \\
\hline $\mathrm{Fe}(\mathrm{III})$ & $\begin{array}{l}\text { Redox immunoreaction of } \\
\text { Fe(III) with transferrin }\end{array}$ & $\begin{array}{l}\text { Immobilization of } \\
\text { transferrin on the surface of } \\
\text { a FET coated with CNT } \\
\text { functionalized with anionic } \\
\text { surfactants. }\end{array}$ & Wine & $\mathrm{AP}$ & 0.050 & 15 & [30] \\
\hline \multirow[t]{21}{*}{$\mathrm{Hg}(\mathrm{II})$} & $\begin{array}{l}\text { GNP release due to bonding } \\
\text { with DNA }\end{array}$ & $\begin{array}{l}\text { Thiolated DNA strands } \\
\text { immobilized on GE coated } \\
\text { with GNP and reduced } \\
\text { graphene oxide. }\end{array}$ & $\begin{array}{l}\text { Tap and natural } \\
\text { waters }\end{array}$ & $\mathrm{CV}$ & 0.0080 & $<0.5$ & [135] \\
\hline & $\begin{array}{c}\text { Inhibition of hybridization } \\
\text { of DNA strands labeled with } \\
\text { MB }\end{array}$ & $\begin{array}{l}\text { Thiolated DNA strands } \\
\text { immobilized on GE } \\
\text { modified with GNP }\end{array}$ & Natural waters & $\mathrm{CV}$ & 0.010 & 120 & [136] \\
\hline & $\begin{array}{l}\text { Bonding with immobilized } \\
\text { oligomer followed by } \\
\text { deposition of Ag }\end{array}$ & $\begin{array}{c}\text { Oligonucleotide } \\
\text { immobilized on GCE via } \\
\text { APM }\end{array}$ & River waters & DPV & $4.0 \times 10^{-4}$ & 50 & [137] \\
\hline & $\begin{array}{l}\text { Hybridization of DNA } \\
\text { strands labeled with MG }\end{array}$ & $\begin{array}{l}\text { Immobilized DNA on CPE } \\
\text { modified with SNP. }\end{array}$ & Tap waters & DPV & 0.0062 & 10 & [138] \\
\hline & $\begin{array}{l}\text { Bonding with DNA strands } \\
\text { labeled with recognition } \\
\text { protein }\end{array}$ & $\begin{array}{c}\text { Immobilized avidin on GNP } \\
\text { deposited on GCE using } \\
\text { EPM }\end{array}$ & Herb digests & DPV & $4.2 \times 10^{-5}$ & 60 & [139] \\
\hline & $\begin{array}{l}\text { Bonding with MA labeled } \\
\text { with quantum dots }\end{array}$ & $\begin{array}{c}\text { Immobilization of conjugate } \\
\mathrm{CH}_{3} \mathrm{Hg} \text {-MA-ovoalbumin on } \\
\text { GCE using GNP }\end{array}$ & Cosmetic digests & ECL & 0.0026 & 60 & [124] \\
\hline & $\begin{array}{l}\text { Hybridization of DNA } \\
\text { strands labeled with MB }\end{array}$ & $\begin{array}{l}\text { Immobilization of thiolated } \\
\text { single-stranded DNA on GE }\end{array}$ & Natural waters & SWV & 0.93 & 30 & [140] \\
\hline & $\begin{array}{l}\text { Complexation with DNA } \\
\text { strands followed by } \\
\text { cleavage by exonuclease III }\end{array}$ & $\begin{array}{l}\text { DNA strands immobilized } \\
\text { on GE modified with } \\
\text { three-dimensional graphene } \\
\text { structure }\end{array}$ & $\begin{array}{l}\text { Tap and lake } \\
\text { waters, and } \\
\text { human serum }\end{array}$ & SWV & $1.0 \times 10^{-8}$ & 240 & [40] \\
\hline & $\begin{array}{l}\text { Hybridization of labeled } \\
\text { DNA strands with MB and } \\
\text { ferrocene }\end{array}$ & $\begin{array}{l}\text { Immobilized single-stranded } \\
\text { DNA labeled with MB on } \\
\text { GE. }\end{array}$ & $\begin{array}{l}\text { Tap and river } \\
\text { waters, and } \\
\text { human serum }\end{array}$ & DPV & 0.016 & 120 & [41] \\
\hline & $\begin{array}{c}\text { Hybridization of DNA } \\
\text { single strands labeled with } \\
{\left[\mathrm{Ru}\left(\mathrm{NH}_{3}\right)_{6}\right]^{3+}}\end{array}$ & $\begin{array}{c}\text { Immobilized thymine-rich } \\
\text { single-stranded DNA on } \\
\text { GCE coated with } \\
\text { polydopamine-capped } \\
\text { graphene oxide. }\end{array}$ & River water & DPV & 1.0 & 30 & [141] \\
\hline & $\begin{array}{l}\text { Hybridization of DNA } \\
\text { strands labeled with HRP }\end{array}$ & $\begin{array}{l}\text { Immobilization of thiolated } \\
\text { thymine-rich } \\
\text { single-stranded DNA on GE. }\end{array}$ & Drinking water & EIS & $8.0 \times 10^{-5}$ & 90 & [142] \\
\hline & $\begin{array}{l}\text { Hybridization of DNA } \\
\text { strands labeled with hemin }\end{array}$ & $\begin{array}{l}\text { Immobilization of thiolated } \\
\text { single-stranded DNA on GE }\end{array}$ & Tap water & $\mathrm{AP}$ & 0.0066 & 120 & [143] \\
\hline & $\begin{array}{c}\text { Complexation with DNA } \\
\text { labeled with MB }\end{array}$ & $\begin{array}{l}\text { Immobilization of DNA } \\
\text { labeled with MB on GE. }\end{array}$ & $\begin{array}{l}\text { Tap, river, and } \\
\text { drinking waters }\end{array}$ & SWV & 0.020 & 60 & [144] \\
\hline & $\begin{array}{l}\text { Complexation and } \\
\text { conformational shift of } \\
\text { immobilized DNA }\end{array}$ & $\begin{array}{l}\text { Single-stranded DNA } \\
\text { immobilized on GE } \\
\text { modified with chitosan and } \\
\mathrm{Cu}_{2} \mathrm{O} \text { nanospheres }\end{array}$ & River water & EIS & 0.030 & NI & [72] \\
\hline & $\begin{array}{l}\text { Complexation and } \\
\text { conformational shift of } \\
\text { immobilized DNA }\end{array}$ & $\begin{array}{l}\text { Immobilized DNA on GCE } \\
\text { coated with polyaniline } \\
\text { nanofiber, ordered } \\
\text { mesoporous carbon, and } \\
\text { GNP }\end{array}$ & $\begin{array}{l}\text { Lake and tap } \\
\text { waters }\end{array}$ & DPV & $1.2 \times 10^{-7}$ & 870 & [73] \\
\hline & $\begin{array}{l}\text { Complexation and } \\
\text { conformational shift of } \\
\text { immobilized DNA }\end{array}$ & $\begin{array}{l}\text { DNA strands labeled with } \\
\text { cysteine immobilized on } \\
\text { nanoporous gold surface }\end{array}$ & NA & SERS & 0.0002 & 30 & [105] \\
\hline & $\begin{array}{l}\text { Hybridization of DNA } \\
\text { strands }\end{array}$ & $\begin{array}{l}\text { DNA immobilized on GCE } \\
\text { modified with } \mathrm{MoS}_{2} \text {, PDDA } \\
\text { and quantum dots }\end{array}$ & $\begin{array}{l}\text { River water, soil, } \\
\text { and milk }\end{array}$ & ECL & $2.0 \times 10^{-5}$ & 120 & [145] \\
\hline & $\begin{array}{l}\text { Hybridization of DNA } \\
\text { strands labeled with } \\
\text { fluorophore }\end{array}$ & $\begin{array}{l}\text { DNA single strands } \\
\text { immobilized on polyaniline } \\
\text { nanoclips support }\end{array}$ & Natural waters & FL & 0.80 & 60 & [62] \\
\hline & $\begin{array}{l}\text { Hybridization of DNA } \\
\text { strands labeled with Ru } \\
\text { complex }\end{array}$ & $\begin{array}{c}\text { Single-stranded DNA } \\
\text { labeled with silica/Ru } \\
\text { nanoparticles immobilized } \\
\text { on GCE modified with GNP. }\end{array}$ & River waters & ECL & $4.0 \times 10^{-6}$ & 70 & [146] \\
\hline & $\begin{array}{l}\text { Hybridization of DNA via } \\
\text { thymine bonding }\end{array}$ & $\begin{array}{l}\text { DNA strands immobilized } \\
\text { on fiber support coated with } \\
\text { gold film and GNP }\end{array}$ & $\begin{array}{l}\text { Tap water and } \\
\text { human serum }\end{array}$ & SPR & 0.00060 & NI & [147] \\
\hline & $\begin{array}{l}\text { DNA dual cycle triggered by } \\
\text { exonuclease III }\end{array}$ & $\begin{array}{l}\text { DNA strands immobilized } \\
\text { on GCE modified with gold } \\
\text { film }\end{array}$ & Drinking water & SWV & $2.4 \times 10^{-8}$ & 60 & [148] \\
\hline
\end{tabular}


Table 3. Cont.

\begin{tabular}{|c|c|c|c|c|c|c|c|}
\hline Analyte & Principle & Remarks & Sample & Technique & $\begin{array}{c}\mathrm{DL} \\
\left(\mu \mathrm{g} \mathrm{L}^{-1}\right)\end{array}$ & $\begin{array}{l}\text { Response } \\
\text { Time (min) }\end{array}$ & Ref. \\
\hline & $\begin{array}{l}\text { Conformational shift of } \\
\text { immobilized aptamer } \\
\text { labeled with Ru-based } \\
\text { composite }\end{array}$ & $\begin{array}{l}\text { Immobilization of aptamer } \\
\text { on GCE coated with GNP }\end{array}$ & $\begin{array}{l}\text { Tap and river } \\
\text { waters }\end{array}$ & ECL & 0.0060 & 90 & [149] \\
\hline & $\begin{array}{l}\text { Quenching of fluorescence } \\
\text { of labeled aptamer after } \\
\text { conformational shift }\end{array}$ & $\begin{array}{l}\text { Immobilization on optical } \\
\text { fibers after modification of } \\
\text { surface with } \\
\text { amino-terminated groups }\end{array}$ & Tap waters & FL & $9.5 \times 10^{-5}$ & 25 & [150] \\
\hline & $\begin{array}{l}\text { DNA dual cycle triggered by } \\
\text { exonuclease III }\end{array}$ & $\begin{array}{c}\text { Immobilization of a 3D DNA } \\
\text { "safebox" on GCE modified } \\
\text { with GNP }\end{array}$ & Tap waters & DPV & $6.6 \times 10^{-6}$ & 90 & [151] \\
\hline & $\begin{array}{l}\text { Hindrance of hybridization } \\
\text { of immobilized DNA }\end{array}$ & $\begin{array}{l}\text { DNA strands immobilized } \\
\text { on GCE modified with } \\
\text { semiconductor }\end{array}$ & $\begin{array}{l}\text { Tap, river and } \\
\text { lake waters }\end{array}$ & ECL & 0.0010 & 120 & [152] \\
\hline \multirow[t]{4}{*}{$\mathrm{K}(\mathrm{I})$} & $\begin{array}{l}\text { Complexation and } \\
\text { conformational shift of } \\
\text { immobilized DNA }\end{array}$ & $\begin{array}{l}\text { Single-stranded DNA } \\
\text { immobilized on GE }\end{array}$ & NA & SWV & 0.083 & 5 & [153] \\
\hline & $\begin{array}{l}\text { Conformational shift of } \\
\text { guanine-rich DNA }\end{array}$ & $\begin{array}{l}\text { Immobilized DNA labeled } \\
\text { with ferrocene on GE coated } \\
\text { with GNP }\end{array}$ & NA & SWV & NI & $<0.5$ & [154] \\
\hline & $\begin{array}{l}\text { Complexation and } \\
\text { conformational shift of DNA }\end{array}$ & $\begin{array}{l}\text { Immobilized DNA on GE } \\
\text { coated with GNP }\end{array}$ & Human urine & SWV & $5.0 \times 10^{-6}$ & $<0.5$ & [155] \\
\hline & $\begin{array}{l}\text { Complexation and } \\
\text { conformational shift of } \\
\text { immobilized DNA }\end{array}$ & $\begin{array}{l}\text { Immobilized thiolated DNA } \\
\text { on GE }\end{array}$ & Human urine & EIS & 0.0039 & NI & [156] \\
\hline $\mathrm{Mg}(\mathrm{II})$ & $\begin{array}{l}\text { Cleavage of DNAzymes } \\
\text { labeled with ferrocene }\end{array}$ & $\begin{array}{l}\text { Immobilization of thiolated } \\
\text { DNAzymes labeled with } \\
\text { ferrocene on GE }\end{array}$ & Human serum & DPV & 1200 & NI & [42] \\
\hline \multirow[t]{2}{*}{$\mathrm{Ni}(\mathrm{II})$} & $\begin{array}{c}\text { Complexation and } \\
\text { conformational shift of DNA } \\
\text { structure with } \\
\text { peroxidase-like activity }\end{array}$ & $\begin{array}{l}\text { Immobilized tetrahedron } \\
\text { DNA structure on GE }\end{array}$ & Human blood & $\mathrm{CV}$ & 0.0088 & 30 & [26] \\
\hline & $\begin{array}{l}\text { Cleavage of immobilized } \\
\text { DNA strands labeled with } \\
\text { CdSe }\end{array}$ & $\begin{array}{l}\text { Immobilized DNA strands } \\
\text { on GE via APM }\end{array}$ & NA & DPV & 0.39 & 60 & [157] \\
\hline \multirow[t]{12}{*}{$\mathrm{Pb}(\mathrm{II})$} & $\begin{array}{l}\text { Bonding and cleavage of } \\
\text { DNA strands }\end{array}$ & $\begin{array}{c}\text { Immobilization of thiolated } \\
\text { DNA strands on GCE } \\
\text { modified with GNP. }\end{array}$ & Natural waters & $\mathrm{AP}$ & $8.7 \times 10^{-5}$ & 120 & [158] \\
\hline & $\begin{array}{c}\text { Cleavage of DNA chain } \\
\text { labeled with Ag } \\
\text { nanoparticles }\end{array}$ & $\begin{array}{l}\text { Immobilized labeled DNA } \\
\text { on GCE coated with GNP }\end{array}$ & Tap waters & LSV & $5.0 \times 10^{-5}$ & 200 & [159] \\
\hline & $\begin{array}{l}\text { Complexation and } \\
\text { conformational shift of DNA } \\
\text { labeled with carbon } \\
\text { dots } / \text { thionine }\end{array}$ & $\begin{array}{c}\text { Immobilization of } \\
\text { thiol-modified aptamer on } \\
\text { GCE }\end{array}$ & $\begin{array}{l}\text { River, tap and } \\
\text { mineral waters }\end{array}$ & DPV & $7.9 \times 10^{-4}$ & 80 & [160] \\
\hline & $\begin{array}{l}\text { Hybridization of DNA } \\
\text { labeled with MOF }\end{array}$ & $\begin{array}{l}\text { Immobilization of } \\
\text { DNAzymes on GNP fixed } \\
\text { on GCE by reduced } \\
\text { graphene oxide }\end{array}$ & $\begin{array}{l}\text { Natural and tap } \\
\text { waters }\end{array}$ & CA & $4.1 \times 10^{-4}$ & 45 & [161] \\
\hline & $\begin{array}{c}\text { Competitive bonding with } \\
\text { EG by DNA }\end{array}$ & $\begin{array}{l}\text { Electrochemical deposition } \\
\text { of DNA on bare CPE or after } \\
\text { modification with CNT }\end{array}$ & $\begin{array}{l}\text { Tap and sea } \\
\text { waters }\end{array}$ & DPV & $\begin{array}{l}0.021 \text { (bare) } \\
0.0055 \\
\text { (CNT) }\end{array}$ & 10 & [162] \\
\hline & $\begin{array}{l}\text { Competitive bonding with } \\
\text { DNA strands labeled with } \\
\text { GNP }\end{array}$ & $\begin{array}{c}\text { Immobilization of } \\
\text { single-stranded DNA on GE }\end{array}$ & Human serum & DPV & 0.031 & 210 & [44] \\
\hline & $\begin{array}{l}\text { Inhibition of hybridization } \\
\text { of DNA strands }\end{array}$ & $\begin{array}{l}\text { Immobilization of DNA } \\
\text { aptamer on quartz crystal } \\
\text { coated with gold layer }\end{array}$ & NA & $\mathrm{QM}$ & 0.83 & 100 & [163] \\
\hline & $\begin{array}{l}\text { Competitive bonding with } \\
\text { anthraquinone-2-sulfonic } \\
\text { acid by DNA strands }\end{array}$ & $\begin{array}{l}\text { Immobilized thiolated } \\
\text { single-stranded DNA on GE }\end{array}$ & NA & DPV & 0.87 & 30 & [164] \\
\hline & $\begin{array}{l}\text { Complexation and } \\
\text { conformational shift of DNA } \\
\text { strands }\end{array}$ & $\begin{array}{l}\text { Immobilized thiolated } \\
\text { single-stranded DNA on GE }\end{array}$ & Tap waters & EIS & 7.2 & 10 & [165] \\
\hline & $\begin{array}{l}\text { Hybridizations of DNA } \\
\text { strands labeled with Ru(II) } \\
\text { complex }\end{array}$ & $\begin{array}{l}\text { Immobilization of DNA } \\
\text { strands on GCE via APM }\end{array}$ & NA & ECL & 0.0013 & 60 & [166] \\
\hline & $\begin{array}{l}\text { Cleavage of DNAzyme } \\
\text { labeled with ferrocene }\end{array}$ & $\begin{array}{l}\text { Immobilization of } \\
\text { ferrocene-labeled DNAzyme } \\
\text { GCE modified with GNP } \\
\text { and reduced graphene oxide }\end{array}$ & $\begin{array}{l}\text { Tap and natural } \\
\text { waters }\end{array}$ & DPV & 0.0031 & 40 & [167] \\
\hline & $\begin{array}{l}\text { Hybridization of DNA } \\
\text { strands labeled with } \\
\text { composite with } \\
\text { peroxidase-like activity }\end{array}$ & $\begin{array}{l}\text { Immobilized single-stranded } \\
\text { DNA on GE }\end{array}$ & $\begin{array}{l}\text { Lake water and } \\
\text { human serum }\end{array}$ & DPV & $6.0 \times 10^{-5}$ & 40 & [45] \\
\hline
\end{tabular}


Table 3. Cont.

\begin{tabular}{|c|c|c|c|c|c|c|c|}
\hline Analyte & Principle & Remarks & Sample & Technique & $\begin{array}{c}\mathrm{DL} \\
\left(\mu \mathrm{g} \mathrm{L}^{-1}\right)\end{array}$ & $\begin{array}{l}\text { Response } \\
\text { Time (min) }\end{array}$ & Ref. \\
\hline & $\begin{array}{l}\text { Hybridization of DNA } \\
\text { strands labeled with hemin, } \\
\text { assigning peroxidase-like } \\
\text { activity }\end{array}$ & $\begin{array}{l}\text { Immobilization of thiolated } \\
\text { DNA on GE }\end{array}$ & River waters & DPV & $7.0 \times 10^{-5}$ & 90 & [168] \\
\hline & $\begin{array}{l}\text { Hybridization of DNA } \\
\text { strands labeled with hemin, } \\
\text { assigning peroxidase-like } \\
\text { activity }\end{array}$ & $\begin{array}{l}\text { Immobilization of thiolated } \\
\text { DNA on GCE after } \\
\text { electrodeposition of a gold } \\
\text { layer }\end{array}$ & $\begin{array}{l}\text { Tap and lake } \\
\text { waters }\end{array}$ & DPV & $7.0 \times 10^{-6}$ & 60 & [169] \\
\hline & Cleavage of DNAzyme & $\begin{array}{l}\text { Immobilization of thiolated } \\
\text { DNAzyme on Si support }\end{array}$ & $\begin{array}{l}\text { Tap, river, and } \\
\text { waste waters }\end{array}$ & SERS & 0.0018 & 70 & [48] \\
\hline & $\begin{array}{l}\text { Hybridization of DNA } \\
\text { strands labeled with hemin, } \\
\text { assigning peroxidase-like } \\
\text { activity }\end{array}$ & $\begin{array}{l}\text { Immobilization of thiolated } \\
\text { DNA organized in } \\
\text { tetrahedral geometry on GE }\end{array}$ & $\begin{array}{l}\text { Tap and pool } \\
\text { waters }\end{array}$ & $\mathrm{CV}$ & 0.0020 & 120 & [170] \\
\hline & $\begin{array}{l}\text { Hybridization of DNA } \\
\text { strands labeled with } \\
\text { recognizing protein }\end{array}$ & $\begin{array}{c}\text { Immobilization of DNA } \\
\text { strands on GE }\end{array}$ & Tap water & DPV & 0.0089 & 230 & [119] \\
\hline & $\begin{array}{l}\text { Hindrance of hybridization } \\
\text { of DNA strands labeled with } \\
\text { thionine and GNP }\end{array}$ & $\begin{array}{l}\text { Immobilization of thiolated } \\
\text { single-stranded DNA on } \\
\text { gold SPE }\end{array}$ & $\begin{array}{l}\text { Tap water and } \\
\text { rat serum }\end{array}$ & DPV & 0.065 & 240 & {$[36]$} \\
\hline & $\begin{array}{l}\text { Cleavage of labeled } \\
\text { DNAzyme }\end{array}$ & $\begin{array}{l}\text { Immobilization of } \\
\text { DNAzyme labeled with } \\
\text { methylene blue and } \\
\text { ferrocene on GE }\end{array}$ & Human serum & $\mathrm{ACV}$ & 0.0095 & 30 & [37] \\
\hline & $\begin{array}{c}\text { Complexation and } \\
\text { conformational shift of DNA } \\
\text { strands labeled with } \\
\text { thionine }\end{array}$ & $\begin{array}{c}\text { Immobilization of } \\
\text { single-stranded DNA } \\
\text { labeled with GNP and } \\
\text { thionine }\end{array}$ & $\begin{array}{l}\text { Tap and river } \\
\text { waters }\end{array}$ & DPV & $6.6 \times 10^{-6}$ & 70 & {$[71]$} \\
\hline & $\begin{array}{l}\text { Interaction with } \\
\text { anti-Pb(II)-ITCBE MA }\end{array}$ & $\begin{array}{l}\text { Antibody immobilized on } \\
\text { nitrocellulose device using } \\
\text { GNP and glass fiber }\end{array}$ & Drinking water & DI & 0.19 & 15 & [171] \\
\hline & $\begin{array}{l}\text { Cleavage of DNAzyme } \\
\text { labeled with GNP }\end{array}$ & $\begin{array}{c}\text { Immobilization of } \\
\text { DNAzyme on gold-coated } \\
\text { quartz crystal }\end{array}$ & Tap water & QM & 2.9 & 40 & [63] \\
\hline & $\begin{array}{l}\text { Cleavage of DNAzyme } \\
\text { labeled with GNP }\end{array}$ & $\begin{array}{l}\text { DNAzyme immobilized on } \\
\text { GE. }\end{array}$ & $\begin{array}{c}\text { Tap and river } \\
\text { waters, and soils }\end{array}$ & $\mathrm{CC}$ & 0.0025 & 45 & [172] \\
\hline & $\begin{array}{l}\text { Cleavage of immobilized } \\
\text { DNA and deposition of Ag }\end{array}$ & $\begin{array}{l}\text { DNA strands immobilized } \\
\text { on GE. }\end{array}$ & River water & SWV & 0.016 & 155 & [173] \\
\hline & $\begin{array}{l}\text { Cleavage of labeled } \\
\text { DNAzyme }\end{array}$ & $\begin{array}{l}\text { Immobilized } \\
\text { ferrocene-labeled DNAzyme } \\
\text { on GE }\end{array}$ & Lake water & DPV & 0.052 & 25 & [174] \\
\hline & $\begin{array}{l}\text { Cleavage of immobilized } \\
\text { DNAzyme }\end{array}$ & $\begin{array}{l}\text { DNAzyme immobilized on } \\
\text { glass surface modified with } \\
\text { GNP and graphene }\end{array}$ & NA & $\mathrm{CD}$ & 0.0041 & 20 & [28] \\
\hline & $\begin{array}{l}\text { Complexation and } \\
\text { conformational shift of DNA } \\
\text { strands labeled with } \\
\text { chemiluminescent molecule }\end{array}$ & $\begin{array}{l}\text { Immobilized DNA labeled } \\
\text { with aminoperylene } \\
\text { derivative on GCE coated } \\
\text { with fullerene and GNP }\end{array}$ & Soil leachates & ECL & $7.2 \times 10^{-5}$ & 60 & [175] \\
\hline & Cleavage of DNA strands & $\begin{array}{l}\text { Immobilized thiolated DNA } \\
\text { on GCE coated with GNP }\end{array}$ & $\begin{array}{l}\text { Tap, lake, and } \\
\text { river waters }\end{array}$ & EIS & 0.041 & 50 & [176] \\
\hline & $\begin{array}{c}\text { Hybridization of DNA } \\
\text { strands labeled with MOF } \\
\text { with peroxidase-like activity }\end{array}$ & $\begin{array}{l}\text { Immobilized labeled DNA } \\
\text { on SPE coated with GNP } \\
\text { sealed with chitosan }\end{array}$ & Soil extracts & $\mathrm{CA}$ & 0.0070 & 90 & [177] \\
\hline & $\begin{array}{l}\text { DNA cleavage followed by } \\
\text { hybridization and labeling } \\
\text { with MB }\end{array}$ & $\begin{array}{l}\text { DNA strands immobilized } \\
\text { on silicon wafer coated with } \\
\text { GNP }\end{array}$ & Tap waters & SERS & 0.00073 & 90 & [178] \\
\hline & $\begin{array}{c}\text { Cleavage of immobilized } \\
\text { DNAzyme }\end{array}$ & $\begin{array}{c}\text { Immobilization of } \\
\text { DNAzyme on gold surface }\end{array}$ & $\begin{array}{l}\text { Tap water and } \\
\text { human serum }\end{array}$ & SPR & 0.0018 & NI & [179] \\
\hline & $\begin{array}{l}\text { Cleavage of immobilized } \\
\text { DNAzyme }\end{array}$ & & Tap waters & EIS & $2.6 \times 10^{-7}$ & 0.25 & [180] \\
\hline & $\begin{array}{l}\text { Conformational shift of } \\
\text { immobilized DNA strands }\end{array}$ & $\begin{array}{l}\text { Immobilization of DNA on } \\
\text { GCE coated with GNP via } \\
\text { APM }\end{array}$ & NA & EIS & 0.00095 & 40 & [181] \\
\hline & $\begin{array}{c}\text { Cleavage of immobilized } \\
\text { DNAzyme }\end{array}$ & $\begin{array}{c}\text { Immobilization of } \\
\text { DNAzyme on GCE modified } \\
\text { with MOF }\end{array}$ & $\begin{array}{l}\text { Lake and tap } \\
\text { waters }\end{array}$ & $\mathrm{AP}$ & 0.000014 & 60 & [182] \\
\hline & $\begin{array}{c}\text { Cleavage of immobilized } \\
\text { DNAzyme labeled with } \\
\text { GNP }\end{array}$ & $\begin{array}{c}\text { Immobilization of } \\
\text { DNAzyme on gold surface }\end{array}$ & Groundwaters & SPR & 0.016 & 25 & [183] \\
\hline & $\begin{array}{c}\text { Cleavage of immobilized } \\
\text { DNAzymes }\end{array}$ & $\begin{array}{l}\text { DNAzymes immobilized on } \\
\text { GCE modified with } \\
\text { quantum dots }\end{array}$ & Cell lysates & ECL & 0.000033 & 140 & [184] \\
\hline & $\begin{array}{l}\text { Bonding with DNA strands } \\
\text { followed by hybridization of } \\
\text { labeled DNA strands }\end{array}$ & $\begin{array}{l}\text { DNA strands immobilized } \\
\text { on GE }\end{array}$ & $\begin{array}{l}\text { Tap and lake } \\
\text { waters }\end{array}$ & DPV & 0.0037 & NI & [185] \\
\hline
\end{tabular}


Table 3. Cont.

\begin{tabular}{|c|c|c|c|c|c|c|c|}
\hline Analyte & Principle & Remarks & Sample & Technique & $\begin{array}{c}D L \\
\left(\mu g L^{-1}\right)\end{array}$ & $\begin{array}{l}\text { Response } \\
\text { Time (min) }\end{array}$ & Ref. \\
\hline \multirow[t]{2}{*}{$\mathrm{Hg}(\mathrm{II}), \mathrm{Pb}(\mathrm{II})$} & $\begin{array}{l}\text { Cleaved DNA strands (for } \\
\mathrm{Pb} \text { ) and conformational shift } \\
\text { (for } \mathrm{Hg} \text { ) }\end{array}$ & $\begin{array}{l}\text { DNA strands immobilized } \\
\text { on GE coated with } \\
\text { amino-functionalized } \\
\text { reduced graphene oxide }\end{array}$ & $\begin{array}{l}\text { Human serum } \\
\text { and tomato juice }\end{array}$ & EIS & $\begin{array}{l}\text { Hg: } 0.0011 \\
\text { Pb:0.0016 }\end{array}$ & 5 & [9] \\
\hline & $\begin{array}{c}\text { Conformational shift of } \\
\text { immobilized DNA altered } \\
\text { ECL }\end{array}$ & $\begin{array}{l}\text { DNA strands immobilized } \\
\text { on GCE modified with } \\
\text { quantum dots }\end{array}$ & Seafood & ECL & $\begin{array}{l}\mathrm{Hg}(\mathrm{II}): \\
0.00082 \\
\mathrm{~Pb}(\mathrm{II}): \\
0.0077\end{array}$ & 60 & [186] \\
\hline
\end{tabular}

Abbreviations were displayed on the "list of abbreviations".

As an alternative to immunoaffinity systems, single and double-stranded nucleic acids, often encompassing those based on simple nucleotides, have been used as recognizing elements in biosensors, generally referred to as aptasensors. Different features make these biomolecules attractive, particularly their ability to be synthesized outside living organisms, yield complexes with formation constants in the nanomolar concentration region, enabling sensor reuse, and their high chemical and thermal inertness [24] compared, for example, to antibodies. Over $90 \%$ of aptasensors for $\mathrm{Cd}(\mathrm{II}), \mathrm{Hg}$ (II), and $\mathrm{Pb}$ (II) exploited the ligand ability of nitrogen to achieve low detection limits (as low as $8.0 \times 10^{-10} \mathrm{ng} \mathrm{L}^{-1}$ ) [81,105]. The bonding of cations to the thymine base from DNA strands was exploited for selective determinations.

The mechanisms were based on conformational shifts and the cleavage or hybridization of DNA strands mediated by metal ions. In addition, DNAzymes were also exploited for detection due to their selective and sensitive reactions with cations. As an example, the determination of $\mathrm{Hg}$ (II) was based on the complexation of the analyte with a thymine (THY) base from an immobilized single-stranded DNA, resulting in the union of a pair of strands [73]. The formed complex interacted with the mediator disodium-anthraquinone2,6-disulfonate (AQDS) via an anthracene ring. Thus, the electrode was covered with AQDS, which enhanced electron transfer and led to an increase in the current signal.

The effects on the conductivity of biosensors due to the conformational shifts of immobilized DNA strands after bonding with metallic ions were also used for biosensing $[9,72,96,98,99,102,130,141,149,150,181]$. In general, the charge transfer was enhanced after the DNA binding to $\mathrm{Cu}(\mathrm{II})[130], \mathrm{Pb}$ (II) $[102,181]$, and $\mathrm{Hg}$ (II) $[9,72,96,98,99,141,149,150]$. On the other hand, the formation of a G-quadruplex structure with a K(I) hindered charge transfer $[155,156]$ and led to detection limits as low as $5.0 \mathrm{pg} \mathrm{L}^{-1}$ for application in urine samples. In this case, the high dilution of the sample contributed to minimizing interferences from concomitants that were present at low concentrations in the sample.

The selective binding of DNA bases to $\mathrm{Hg}(\mathrm{II})$ and $\mathrm{Pb}(\mathrm{II})$ was also used for the development of procedures based on responses due to the cleavage or the hybridization of DNA strands. These reactions promote the (dis)assembly of DNA strands and aptamers labeled with a chemical mediator, such as methylene blue, ethyl green, ferrocene, and gold nanoparticles $[9,36,37,41,137,159,175]$ for bioelectrochemical sensors. Competitive reactions between analyte and chemical mediators with immobilized oligonucleotides were also reported [71,140,153,160,162,164,165].

Compared to proteins or RNA molecules, DNAzymes are an excellent choice for metal ion detection because of their relatively low cost and high stability toward hydrolysis. All of these features make the metal-dependent DNAzymes particularly attractive as a biosensor platform for selective metal ion detection. The mechanism is based on the immobilization of double-stranded DNA comprising a substrate and an enzyme strand that can hybridize to the substrate through two base-pairing regions. The $5^{\prime}$-portion of the enzyme binds the substrate and the $3^{\prime}$-region through the formation of a DNA triplex. In the presence of the cation, the substrate is cut at the cleavage site (deoxyguanosine) and the fragments are released, leaving a part of the substrate strand immobilized on the sensor. In this regard, DNAzymes were exploited for fluorescent and electrochemical sensors for the determination of $\mathrm{Pb}$ (II) $[9,28,45,63,158,166,167,172-175,179,180], \mathrm{Cu}(\mathrm{II})$ [133], Cd(II) [126], 
$\mathrm{Hg}$ (II) $[40,135,138], \mathrm{Mg}$ (II) [42], and Ni(II) [157]. In these procedures, substrate strands were labeled with electrochemical and fluorescent probes that showed responses after their disassembly from the platform. Alternatively, strands labeled with enzymes, such as peroxidase, were used $[44,119,142]$ to monitor the enzymatic reactions.

In modern approaches, the labeling of DNAzymes with porphyrins [143,168-170], composites [45], and metal-organic frameworks (MOF) [131,161,177] were also proposed due to their enzyme-like activities. The bonding of hemin to DNA strands catalyzed the decomposition of $\mathrm{H}_{2} \mathrm{O}_{2}$ [187]. On the other hand, iron-based MOF [131,161,177] acted on the decomposition of $\mathrm{H}_{2} \mathrm{O}_{2}$ via a Fenton reaction [188]; thus, the consumption of hydrogen peroxide and the generation of hydroxyl radicals were exploited to yield analytical signals. As an additional advantage, these replacing catalysts were more stable than enzymes, which minimized the susceptibility of the biosensors to degradation.

The mechanisms discussed are schematically summarized in Figure 3.

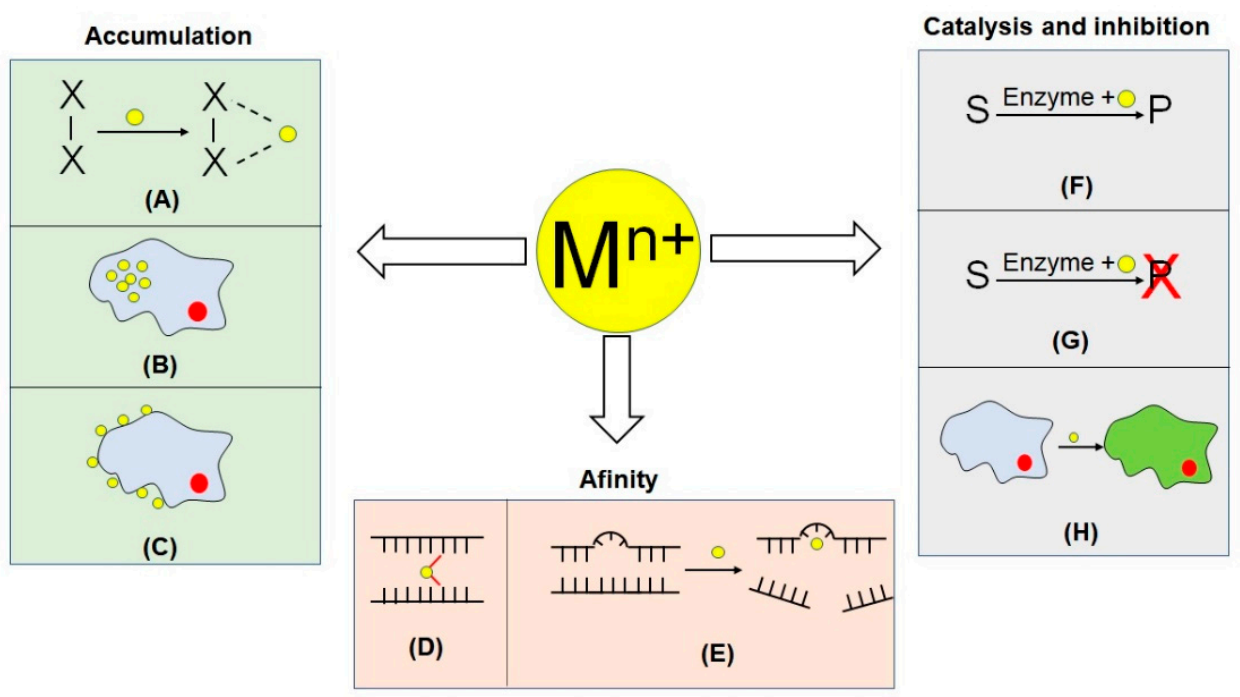

Figure 3. Scheme of the main mechanisms of biosensors for metal ions determinations. (A): Metal coordination; (B): bioaccumulation; (C): biosorption; (D): hybridization of DNA strands; (E): DNAzymes reactions; (F): Enhancement of enzymatic activity; (G): inhibition of enzymatic activity; (H): metabolism alteration of cells; S: substrate; P: product; X: generic element; $\mathrm{Mn+:}$ generic cation.

\section{Biosensors Platforms}

The immobilization or entrapment of biosensing structures varied according to the transducing strategy, which was usually carried out with electrochemical, optical, and vibrational approaches. The best stability and performance are the main features that must be considered for the construction of biosensors. Figure 4 shows the main components of platforms used for the construction of biosensors. 


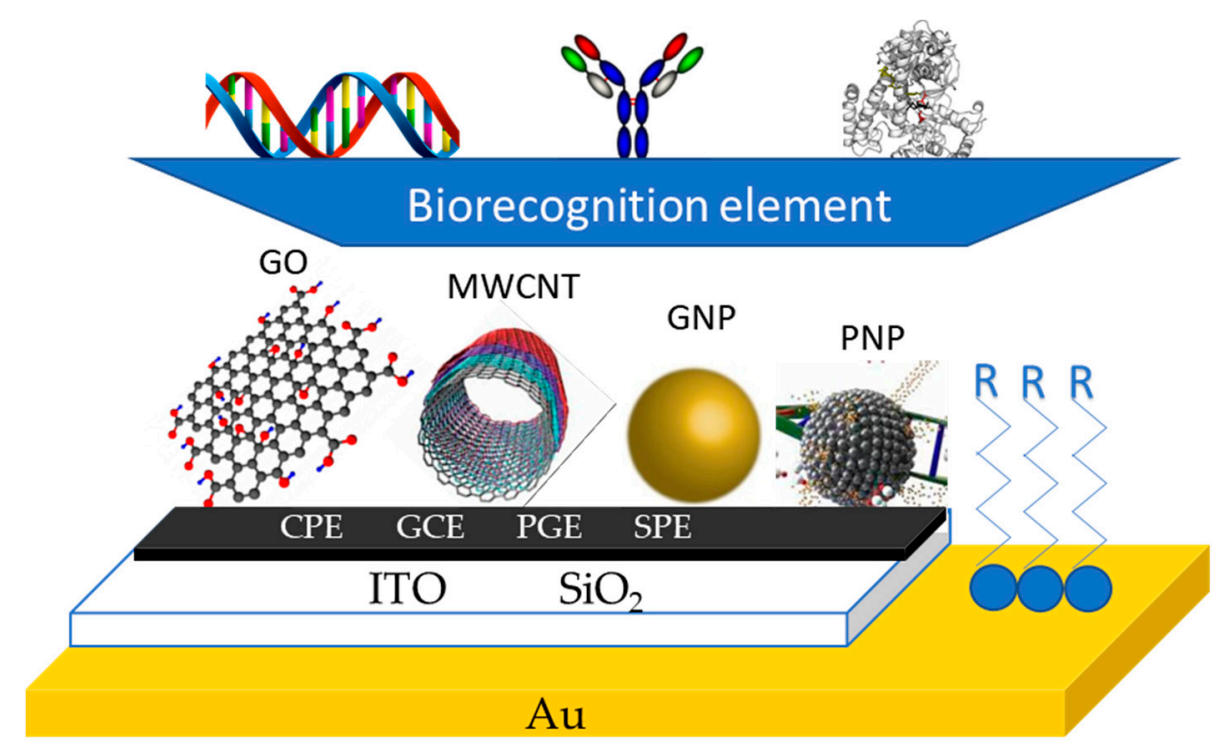

Figure 4. Schematic representation of possible compositions and treatments of layers of biosensors platforms.

\subsection{Electrochemical Sensors}

Electrochemical sensors are most often constructed using an electrode as a physical support for the biorecognition element. GE and electrochemically gold-coated GCE were the commonly employed platforms due to their chemical inertness, high conductivity, and the simple steps required for the immobilization of biomolecules. The interaction of gold with thiol groups via a redox reaction led to a self-assembled monolayer on the metallic surface, resulting in the deposition of gold thiolates [189]. The execution of simple steps such as dip and drop coatings allowed for an easy immobilization of the naturally or synthetically thiolated molecules, such as peptides and DNA strands, after 2 to $12 \mathrm{~h}$ of contact with the surface $[9,26,36,37,42,44,59,73,98,119,124,127,133,140,143,144,153,156,158,164,165,167-169,172,176]$. Alternatively, the gold layer was modified with mercaptohexanol [134,168], hexanethiol [159], and aminothiophenol $[154,155]$ to immobilize the target molecules and nanoparticles. Special attention is needed when executing this approach to avoid the sensor lacking conductivity due to the deposition of high quantities of organic compounds.

Amino and carbonyl groups were used to form peptide bonds with proteins and enzymes, whereas the presence of hydrophobic groups enabled the immobilization of nonpolar molecules via $\pi-\pi$ stacking. The modification of gold surfaces with 3-mercaptopropionic acid (MPA) followed by the coupling reaction with $\mathrm{N}$-ethyl- $\mathrm{N}^{\prime}$-(3-dimethylaminopropyl) carbodiimide hydrochloride (EDC) and N-hydroxysuccinimide (NHS) enabled the formation of active ester sites (amino polymerization method) [66,93]. Thiolated molecules such as mercaptohexanol [134] were also added after immobilization to prevent the bonding and adsorption of concomitants in the sample, mainly proteins.

The amino polymerization method has also been employed for the modification of GCE without a metallic coating. In this case, carboxyl groups were generated on the carbon surface after electrochemical oxidation to enable the polymerization reaction [91,137]. Alternatively, the modification of an electrode was carried out with carboxylated carbon nanotubes (CNT), which was applied for the immobilization of glucose oxidase, aiming at Cd(II) determination [69].

The electrochemical deposition of DNA on modified PGE was an ingenious and fast approach exploited for $\mathrm{Hg}$ (II) determination in seawaters and seafood [81]. The preparation of the sensor was faster compared to the chemical modifications that generally required 30-60 min to assemble the sensing biomolecule.

A common modification of biosensing platforms has been carried out with reduced graphene derivatives $[9,28,40,46,69,98,99,135,141,161,167,173]$, which show high thermal, 
chemical, and mechanical stability [64]; good biocompatibility [135]; and high conductivity, especially reduced graphene oxide. As an example, the current signals of cyclic voltammograms obtained with a ferrocyanide solution increased two-fold after coating the GCE electrode with reduced graphene oxide, aiming at the immobilization of polynucleotides for $\mathrm{Pb}$ (II) determination [167]. The adherence of graphene on carbon-based surfaces required drop coating as a simple and fast preparation step. Due to the few oxygenated functional groups, the chemical modifications of biomolecules were not often exploited for immobilization on graphene-modified surfaces [40]. Except for single strand DNA, which interacted with reduced graphene oxide via $\pi-\pi$ stacking [173], biomolecules were generally retained by polymeric nets or immobilized after the deposition of gold nanoparticles (GNP) [167].

As an alternative to immobilization, the entrapment of biomolecules by surface coating with polymers $[19,47,69,107,139]$ and sol-gel materials $[14,53]$ has been stated. The chosen materials must produce adequate layers for containment, presenting low solubility and high stability in the measurement medium (generally water). In addition, adequate porosity must be sought to enable the diffusion of analytes and mediators. Artificial polymers such as Nafion ${ }^{\circledR}$ were used for the determination of Cd(II) [69,107], Cu(II) [19,47], $\mathrm{Hg}$ (II) [139], and $\mathrm{Pb}$ (II) [19]. In general, a suspension of the polymer (mixed or not with the sensing system) was dropped onto the electrode and left to dry prior to analytical applications.

Polymers from natural sources such as chitin [95], gelatin [106], and chitosan $[11,72,160,177]$ layers were employed with simple steps for electrode modification. Despite the greenness of this alternative, the solubility of biopolymers in water is generally higher than artificial ones, which hinder the lifetime of the sensors. Furthermore, they are more susceptible to dissolution due to $\mathrm{pH}$ and ionic strength variations. Nevertheless, their simplicity and environmentally friendly feature must be highlighted as adequate choices for the construction of biosensors.

Biosensors for metal ions analysis have also been constructed by mixing the components of the electrodes with the sensing biomolecule. The amperometric determination of $\mathrm{Mn}(\mathrm{II})$ [116] was carried out by mixing a carbon paste electrode with HRP to give rise to an electrode. Despite the simplicity, the lifetime of the electrode is compromised due to the leaching of the enzyme. Additionally, the repeatability and reproducibility might be hindered as well. Nevertheless, a discussion on electrode lifetime and precision was neglected in this work, indicating that further studies must be carried out before the application of this biosensor. Lifetime drawbacks can be attenuated by retaining the sensing biomolecule in a plastic membrane, as it was proposed for the determination of $\mathrm{Mg}$ (II) [100].

A modified $\mathrm{Fe}_{3} \mathrm{O}_{4}$ magnetic solid was used for the simultaneous determination of $\mathrm{Cd}(\mathrm{II})$ and $\mathrm{Pb}$ (II) in natural waters [17]. After synthesis, the magnetic particles were bonded to glutathione (via sulfhydryl groups) that acted as a complexing agent of the analytes. The biosensor was prepared by ingeniously coupling a GCE on the tip of a PTFE tube filled with a magnet. In this way, the sensing magnetic particles were retained at the outer surface of the GCE due to the electromagnetic attraction to the inner magnet. This simple strategy showed good performance for the analysis of natural waters, paving the way for the construction of other sensors using the same principle of immobilization.

Additional platforms used for the construction of biosensors include indium tin oxide glass (ITO) electrodes and field-effect transistors (FET). The former, known for its high conductivity and transparency, was employed for the determination of $\mathrm{Cu}$ (II) in tap water [92] after the electrodeposition of GNP modified with amino acids. Modifications of FET sensors were carried out at the $\mathrm{SiO}_{2}$ gate of the device and used for Cd(II) [129], $\mathrm{Cu}$ (II) [39], $\mathrm{Fe}$ (III) [30], and $\mathrm{Ca}$ (II) [84,125] determinations in biological fluids and drinks. The silanization of the gate was required using amino-terminated silane, such as aminopropyltriethoxisilane [39]. Afterward, glutaraldehyde was added to form a bridge with a carboxyl group terminal that allowed biomolecules to bond to amino groups. Graphenebased FET was also employed for the determination of $\mathrm{Hg}$ (II) in mussel digests [99] via the immobilization of aptamers on the sensor. An additional feature of FET biosensors was 
the miniaturization that required low volumes of sample for analysis, especially for those applications on biological materials $[39,84]$. Other approaches include modified electrodes of commercial oximeters $[49,54,67,68,106]$ based on an electrode coating with biofilms and the use of MFC for element analysis [50,52].

\subsection{Optical and Piezoelectric Sensors}

To a lesser extent than electrochemical biosensors, optodes have been applied to element analysis exploiting molecular absorption spectrophotometry (MAS) [104,114], SERS $[48,105,178]$, SPR $[64,65,147,179]$, IRS [108], digital imaging (DI) [109,171], and FL $[58-62,150]$. The latter was frequently used due to the simplicity of the instrumentation and the ease of detection. In general, the construction of optosensors was based on the entrapment of the sensing biomolecule or whole cells with polyacrylamide $[60,114]$, tetramethoxysilane sol-gels [58], and calcium alginate beads [109]. In this case, the porosity must be adequate to favor the diffusion of the analyte.

Polyaniline was used to immobilize sensing biomolecules via an interaction with amino groups. The devices were constructed with a solid piece of the polymer [62] or with an electrochemically coated optical fiber [104] aiming at $\mathrm{Cu}$ (II) determinations. Silicon-based platforms were also employed for the quantification of $\mathrm{Cu}$ (II) [108] and $\mathrm{Pb}$ (II) [48] in natural waters. For enzyme immobilization, the surface of the platform was silanized with aminopropyl(triethoxyl)silane and diisopropylethylamine before the enzyme's assembly. Alternatively, the immobilization of biomolecules was carried out after chemically depositing silver nanoparticles.

Biosensors constructed with gold platforms were also used for optical detection by SERS [65] and SPR [64]. In this case, the immobilization of biomolecules was carried out as previously discussed for electrodes exploiting reactions with gold. In addition, gold platforms were also used for biosensors with piezoelectric responses $[63,163]$. In this case, quartz microbalances were coated with a gold film, which allowed the attachment of polynucleotides via thiol groups bonding, allowing for the determination of $\mathrm{Pb}(\mathrm{II})$ in waters.

\section{Nanomaterials in Biosensing Detection}

Nanomaterials have unambiguously set their place in many areas. They have been employed both as a recognition and support agent in biosensing detection due to their chemical, physical, electrical, and optical properties compared to bulk materials [92]. Furthermore, the modification of sensors with nanoparticles, especially electrodes, yielded higher stability, sensitivity, and repeatability [30]. Coating platforms with nanomaterials yields higher chemical and mechanical stability, thus the lifetime of the biosensors is elongated. Better precision is related to stability because lower signal deviations are observed when degradation of the device is avoided. In addition, immobilized enzymes show an enhanced stability and activity, hence coating electrodes with nanomaterials can be easily carried out to achieve the biomolecules' immobilization [190]. The usual nanomaterials employed in biosensors and their benefits are schematically shown in Figure 5.

Over $30 \%$ of the proposed procedures for metal determinations employed biosensors modified with nanoparticles. Modifications were carried out with GNP $[7,28,36,40,44,48,63,71,73,76,81,131,133,135,139,142,155,158,161,163,167,171,172,175-177]$, CNTs $[11,19,30,69,107,117,162]$, silver nanoparticles (SNP) [51,138,159], mesoporous carbon [62,73], fullerenes [175], and quantum dots [124,157,184,186]. Coating GE biosensors with GNPs $[135,155]$ aimed to increase the surface area to enhance its sensitivity. The response of the determination of $\mathrm{Hg}$ (II) increased up to $60 \%$ with a GNP-coated electrode compared to a bare GE [135]. The electrochemical and adsorptive coatings of GCE [98,124,133,139,158,159,167,175], SPCE [96], paper [59,76], and glass [28,92,131] sensors with GNP allowed for the immobilization of compounds via thiol bonding and higher conductivity to achieve low detection limits. The deposition of reduced graphene oxide was 
generally used to modify carbon-based sensors before the deposition of GNP to enhance the sensitivity due to the synergistic effect of these materials $[40,135]$. In addition to the coating of sensors, DNA strands were also bonded to GNPs to act as recognizing factors, such as that proposed for $\mathrm{Hg}(\mathrm{II})$ determination in natural waters [136]. In this work, labeled DNA strands with nanoparticles adhered to the biosensor surface after hybridization with the immobilized complementary strands, which improved the conductivity and, consequently, the electron transfer.

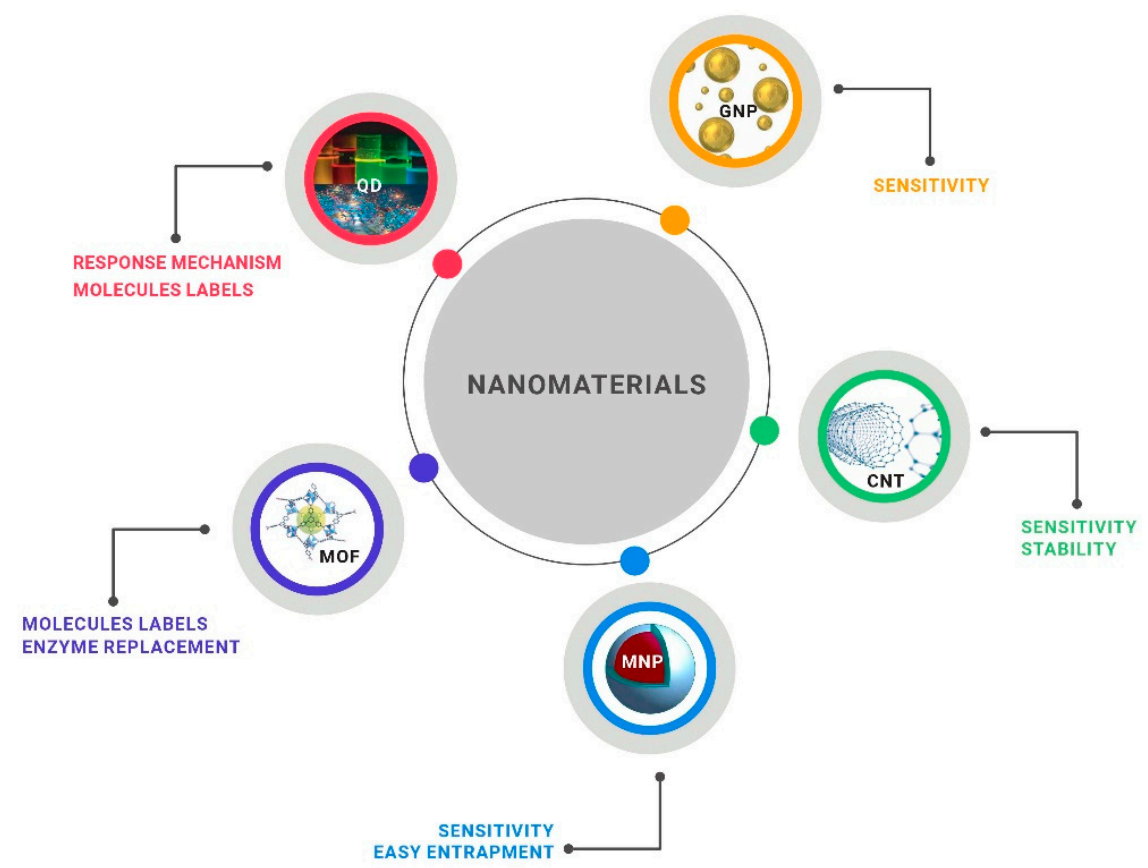

Figure 5. Types of nanomaterials commonly used in structured biosensors and their main contributions to the devices' performance.

The use of SNP was also exploited for lowering detection limits by enhancing the conductivity of the sensor. The low stability of metallic silver nanoparticles is the main limitation to its use; however, it was explored as a support for biomolecules aiming to determine $\mathrm{Hg}$ (II) [138], $\mathrm{Cu}(\mathrm{II})$ [51], and $\mathrm{Pb}(\mathrm{II})[159,173]$.

The use of CNT in biosensors has been proposed to obtain high stability, an improved conductivity, and a faster electron transfer rate of redox reactions [38]. The interaction with carbon-based electrodes via $\pi-\pi$ stacking allowed an efficient dip coating of the surface with suspensions of CNT [162]. On the other hand, the limited binding sites of CNTs required (electro)chemical modifications to enhance the performance of the biosensors. The affinity of modified CNTs with amino groups was used to immobilize biomolecules, such as antibodies [30], and mediators (e.g., polydiallyldimethylammonium) [38]. Modification with carboxyl groups (obtained by mixing $\mathrm{CNT}$ and $\mathrm{HNO}_{3}$ ) paved the way for cross-linking enzymes in the presence of glutaraldehyde [117] and the polymerization method [69]. In both cases, the stable bonding of biomolecules with the surface was achieved.

Other carbon-based materials were employed in biosensors for metal analysis, leading to procedures with low detection limits $[73,160,175,176]$. The determination of $\mathrm{Pb}$ (II) was carried out with a biosensor modified with entrapped carbon dots doped with nitrogen and phosphorus to enhance conductivity [160]. In this case, one of the lowest detection limits was achieved with a GCE for $\mathrm{Pb}(\mathrm{II})$ determination in natural waters, estimated at $0.79 \mathrm{ng} \mathrm{L}^{-1}$. In this sense, ordered mesoporous carbon was also assessed for enhancing the performance of aptasensors that showed detection limits as low as $41 \mathrm{ng} \mathrm{L}^{-1}$ for $\mathrm{Pb}$ (II) [176] and $0.12 \mathrm{pg} \mathrm{L}^{-1}$ for $\mathrm{Hg}(\mathrm{II})$ [73].

To a small extent, nanomaterials based on palladium [45], $\mathrm{Fe}_{3} \mathrm{O}_{4}$ [17], polypyrrol [47,70], $\mathrm{ZnO}$ [191], and CdSe quantum dots [124] were also used for the construction of biosensors 
for metal ions analysis aiming at the enhancement of conductivity, but the analytical features were not improved compared to biosensors conceived with other nanomaterials. Additionally, the electrochemical deposition of bulk polypyrrole yielded detection limits twice as low as that of the sensors prepared with nanomaterials of the same compound.

\section{Multielement Analysis}

The analysis of multiple metal ions with biosensors has been proposed in few articles $[7-19,186]$. Despite the adequate response to various cations, most procedures were not selective enough for simultaneous or sequential determinations. This is a difficult achievement because the responses derived from similar biochemical mechanisms, based on interactions with DNA strands [9,186], whole cells [12], proteins [7,17], and enzyme sites $[8,10,11,13-16,18,19]$.

In general, the response intensities tend to be different for each cation due to variable reaction mechanisms, kinetics, and stability constants [11]. Therefore, an order of reactivity can be assessed to avoid interferences. For example, the determination of Cd(II), Co(II), $\mathrm{Cu}(\mathrm{II})$, and $\mathrm{Ni}$ (II) was carried out based on bonding with glucose oxidase sites that hindered the coordination of glucose with the enzyme [8]. Despite the same mechanism being observed for the assessed cations, the inhibition of enzymatic activity was more pronounced after the addition of $\mathrm{Cd}(\mathrm{II})$, followed by $\mathrm{Co}(\mathrm{II}), \mathrm{Ni}(\mathrm{II})$, and $\mathrm{Cu}(\mathrm{II})$. The biosensor showed versatility for the determination of the analytes, but mutual determinations without sample preparation were unlikely. For this reason, $30 \%$ of the biosensors proposed for multielement determination were not applied to the analysis of real samples without additional strategies for differentiation $[8,10,12,14]$.

A standard addition method was one alternative to solve the problem and was used for $\mathrm{Cu}(\mathrm{II})$ and $\mathrm{Pb}(\mathrm{II})$ determination in tap waters [19], and $\mathrm{Hg}(\mathrm{II}), \mathrm{Cd}(\mathrm{II}), \mathrm{Pb}(\mathrm{II})$, and $\mathrm{Cr}(\mathrm{VI})$ in milk [11]. Therefore, the interference of other metal ions was considered as matrix effects, which was minimized by this type of calibration. However, this strategy can be ineffective for some concentration ranges of the interfering ions. Additionally, tiring and laborious steps were usually attributed to this strategy with solution handling that can lead to systematic errors.

For multielement quantification, masking agents were also used to enhance accuracies, such as for the sequential determination of $\mathrm{Cu}$ (II) and $\mathrm{Zn}$ (II) in human serum using a urease-based biosensor [7]. At first, $\mathrm{Cu}$ (II) was quantified after masking $\mathrm{Zn}$ (II) with pyrophosphate, thus only $\mathrm{Cu}$ (II) was bonded with enzyme sites. Afterward, Zn(II) was determined using another portion of the sample containing thiourea as a masking agent for $\mathrm{Cu}(\mathrm{II})$. Despite the two-step determination of cations, simple approaches for sequential multi-element quantification enabled the exploitation of a versatile biosensor. As the response was obtained after $5 \mathrm{~min}$, the procedure was suitable for applications in clinical laboratories.

Speciation analysis of chromium in tap and wastewaters was achieved with a biosensors array [5]. $\mathrm{Cr}(\mathrm{III})$ and $\mathrm{Cr}(\mathrm{VI})$ determinations were based on the inhibition of tyrosinase and glucose oxidase, respectively. Each enzyme was immobilized on a GCE platform that allowed selective and simultaneous responses for each oxidation state of chromium. This ingenious alternative for speciation analysis has scarcely been exploited and could be further applied for the differentiation of chemical species simultaneously.

\section{Conclusions and Trends}

An evolution of the development of biosensors for metal ion analysis has been observed in the past few years. Exploring various mechanisms and materials for their construction allowed for the quantification of analytes at low concentrations, in some cases, at ng $\mathrm{L}^{-1}$ levels. In the meantime, these powerful strategies to achieve such sensitive procedures require extreme caution to avoid contamination and analyte loss. As for highlights, modifications with nanomaterials and conducting polymers allowed the achievement of such good performance for determination of metal cations. 
Electrochemical sensors are by far the most employed ones for quantification, especially due to the inexpensive instrumentation, the fast responses, and the ease of sensor preparation. On the other hand, optodes can yet be widely exploited for the construction of biosensors given the evolution of materials regarding transparency and the possible chemical modifications for the immobilization of biomolecules. As a highlight, affordable instrumentation aiming at spectroanalytical determinations with biosensors has much that is yet to be exploited. Although automated miniaturized procedures are sought for in situ and laboratory analysis, the prolongated response time of most described biosensors hinders this approach.

Studies of important parameters, such as lifetime, possible reuse, and real applications, which could provide essential information, were not always carried out. By despising real sample analysis, especially for multielement determination, the effects of the matrix and concomitants on the biosensor performance are neglected. Thus, the use of the developed procedures becomes highly restricted.

Applications of biosensors for multielement and speciation analysis should be sought by applying adequate sample preparation and statistical treatments, which expand the applicability of one type of sensor. Selective extractions may contribute to sequential determinations of multiple analytes, but this is not a simple task to be developed. On the other hand, chemometric tools can be used in a simple way to differentiate the response of analytes, which has already been exploited previously [192]. As many works have applied the developed procedures for the analysis of $\mathrm{Hg}(\mathrm{II}), \mathrm{Cd}(\mathrm{II}), \mathrm{Cu}(\mathrm{II})$, and $\mathrm{Pb}$ (II), the determination of other elements, including rare earth, should be assessed more often.

Author Contributions: D.L.R.: Conceptualization, methodology, formal analysis, investigation, resources, data curation, writing-original draft preparation, writing—review and editing, visualization, supervision, project administration, funding acquisition. V.M.: Investigation, data curation, writing-original draft preparation, visualization. C.M.P.G.A.: Conceptualization, formal analysis, investigation, resources, writing-review and editing, visualization, supervision. A.N.A.: Resources, writing—review and editing, visualization. M.d.C.B.S.M.M.: Conceptualization, formal analysis, investigation, resources, writing-review and editing, visualization, supervision, project administration, funding acquisition. All authors have read and agreed to the published version of the manuscript.

Funding: This work was supported by São Paulo Research Foundation (FAPESP), grant number [2018/131579-0], in part by the Coordenação de Aperfeiçoamento de Pes-soal de Nível Superior-Brasil (CAPES)-Finance Code 001, and through the project UIDB/50006/2020, funded by FCT/MCTES through national funds.

Institutional Review Board Statement: Not applicable.

Informed Consent Statement: Not applicable.

Data Availability Statement: Data will be furnished under request.

Conflicts of Interest: The authors declare no conflict of interest.

\author{
Abbreviations \\ ABTS 2,2'-Azino-bis(3-ethylbenzothiazoline-6-sulfonic acid) \\ ACV alternate current voltammetry \\ AFM atomic force microscopy \\ AP amperometry \\ APM amino polymerization method \\ APTS 3-aminopropyltriethoxysilane \\ ASV anodic stripping voltammetry \\ BSA bovine serum albumine \\ CA chronoamperometry \\ CC chronocoulometry
}




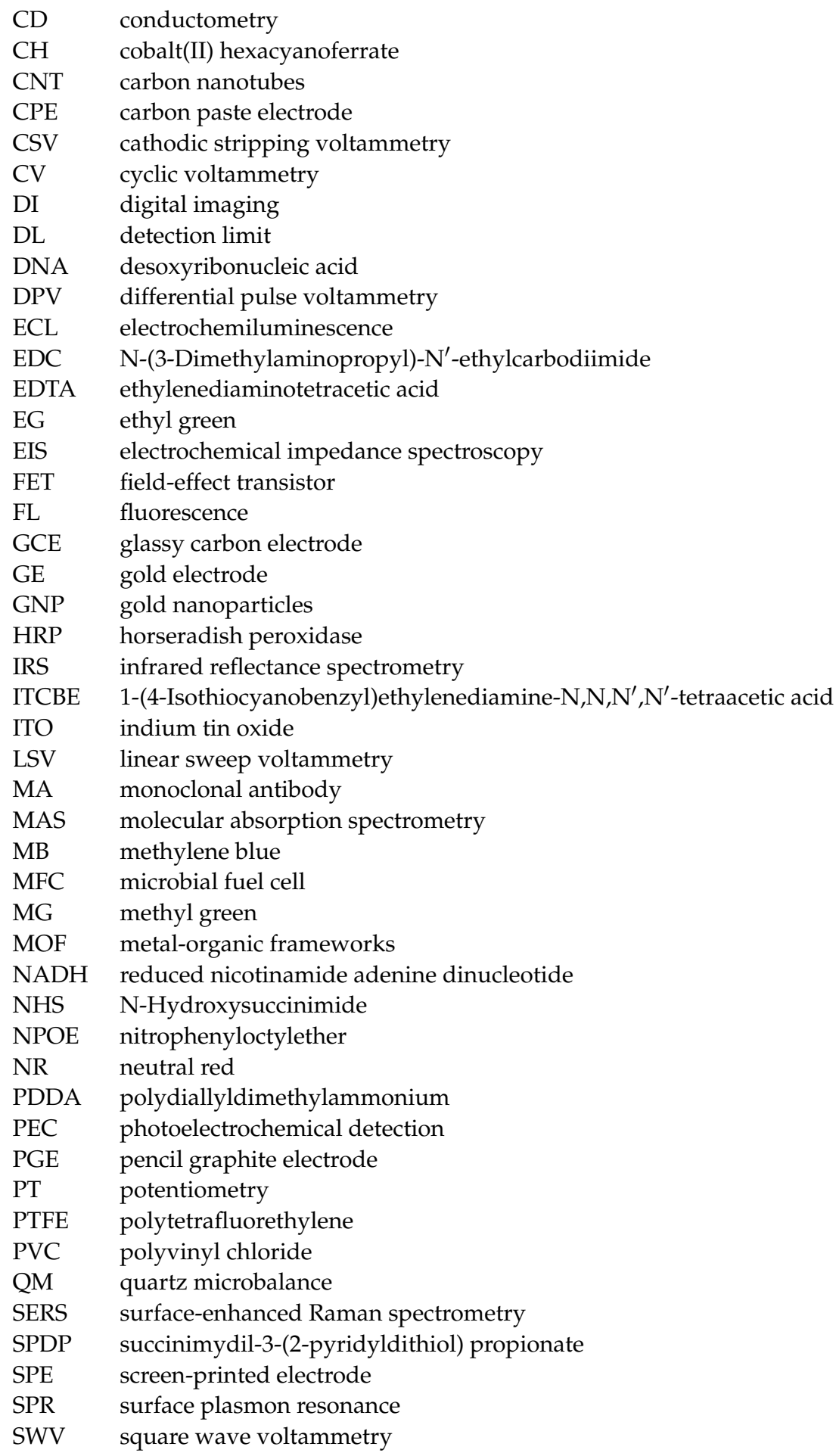

\section{References}

1. McNaught, A.D.; Wilkinson, A. IUPAC Compendium of Chemical Terminology, 2nd ed.; The "Gold Book"; Blackwell Scientific Publications: Oxford, UK, 1997; ISBN 0-9678550-9-8.

2. Nagel, B.; Dellweg, H.; Gierasch, L.M. IUPAC Glossary for chemist for terms used in biotechnology. Compend. Chem. Terminol. 1997, 64, 143-168. [CrossRef]

3. Cui, L.; Wu, J.; Ju, H. Electrochemical sensing of heavy metal ions with in-organic, organic and biomaterials. Biosens. Bioelectron. 2015, 63, 276-286. [CrossRef]

4. Chambers, J.P.; Arulanandam, B.P.; Matta, L.L.; Weis, A.; Valdes, J.J. Biosensor recognition elements. Curr. Issues Mol. Biol. 2002, $10,1-12$. 
5. Calvo-Pérez, A.; Domínguez-Renedo, O.; Alonso-Lomillo, M.; Arcos-Martínez, M. Speciation of chromium using chronoamperometric biosensors based on screen-printed electrodes. Anal. Chim. Acta 2014, 833, 15-21. [CrossRef]

6. Prabhakaran, D.C.; Ramamurthy, P.C.; Sivry, Y.; Subramanian, S. Electro-chemical detection of $\mathrm{Cr}(\mathrm{VI})$ and Cr(III) ions present in aqueous solutions using bio-modified carbon paste electrode: A voltammetric study. Int. J. Environ. Anal. Chem. 2020, 1-21. [CrossRef]

7. Tadi, K.K.; Alshanski, I.; Mervinetsky, E.; Marx, G.; Petrou, P.; Dimitrios, K.M.; Gilon, C.; Hurevich, M.; Yitzchaik, S. OxytocinMonolayer-Based Impedimetric Biosensor for Zinc and Copper Ions. ACS Omega 2017, 2, 8770-8778. [CrossRef]

8. Ghica, M.E.; Carvalho, R.C.; Amine, A.; Brett, C.M.A. Glucose oxidase enzyme inhibition sensors for heavy metals at carbon film electrodes modified with cobalt or copper hexacyanoferrate. Sens. Actuators B Chem. 2013, 178, 270-278. [CrossRef]

9. Wang, M.; Zhang, S.; Ye, Z.; Peng, D.; He, L.; Yan, F.; Yang, Y.; Zhang, H.; Zhang, Z. A gold electrode modified with aminomodified reduced graphene oxide, ion specific DNA and DNAzyme for dual electrochemical determination of $\mathrm{Pb}(\mathrm{II})$ and $\mathrm{Hg}(\mathrm{II})$. Microchim. Acta 2015, 182, 2251-2258. [CrossRef]

10. Do, J.S.; Lin, K.H. Kinetics of urease inhibition-based amperometric biosensors for mercury and lead ions detection. J. Taiwan Inst. Chem. Eng. 2016, 63, 25-32. [CrossRef]

11. da Silva, W.; Ghica, M.E.; Brett, C.M.A. Biotoxic trace metal ion detection by enzymatic inhibition of a glucose biosensor based on a poly(brilliant green)-deep eutectic solvent/carbon nanotube modified electrode. Talanta 2020, 208, 120427. [CrossRef]

12. Wong, L.S.; Lee, Y.H.; Surif, S. Whole cell biosensor using Anabaena torulosa with optical transduction for environmental toxicity evaluation. J. Sens. 2013, 2013, 567272. [CrossRef]

13. Ayenimo, J.G.; Adeloju, S.B. Rapid amperometric detection of trace metals by inhibition of an ultrathin polypyrrole-based glucose biosensor. Talanta 2016, 148, 502-510. [CrossRef]

14. Ilangovan, R.; Daniel, D.; Krastanov, A.; Zachariah, C.; Elizabeth, R. Enzyme based biosensor for heavy metal ions determination. Biotechnol. Biotechnol. Equip. 2006, 20, 184-189. [CrossRef]

15. Attar, A.; Ghica, M.E.; Amine, A.; Brett, C.M.A. Comparison of Cobalt Hexacyanoferrate and Poly(Neutral Red) Modified Carbon Film Electrodes for the Amperometric Detection of Heavy Metals Based on Glucose Oxidase Enzyme Inhibition. Anal. Lett. 2015, 48, 659-671. [CrossRef]

16. Silwana, B.; Van Der Horst, C.; Iwuoha, E.; Somerset, V. Amperometric determination of cadmium, lead, and mercury metal ions using a novel polymer immobilized horseradish peroxidase biosensor system. J. Environ. Sci. Health Part A Toxic/Hazard. Subst. Environ. Eng. 2014, 49, 1501-1511. [CrossRef]

17. Baghayeri, M.; Amiri, A.; Maleki, B.; Alizadeh, Z.; Reiser, O. A simple approach for simultaneous detection of cadmium(II) and lead(II) based on glutathione coated magnetic nanoparticles as a highly selective electrochemical probe. Sens. Actuators B Chem. 2018, 273, 1442-1450. [CrossRef]

18. Ayenimo, J.G.; Adeloju, S.B. Inhibitive potentiometric detection of trace metals with ultrathin polypyrrole glucose oxidase biosensor. Talanta 2015, 137, 62-70. [CrossRef]

19. Moyo, M.; Okonkwo, J.O.; Agyei, N.M. An amperometric biosensor based on horseradish peroxidase immobilized onto maize tassel-multi-walled carbon nanotubes modified glassy carbon electrode for determination of heavy metal ions in aqueous solution. Enzym. Microb. Technol. 2014, 56, 28-34. [CrossRef]

20. Kim, H.; Jang, G.; Yoon, Y. Specific heavy metal/metalloid sensors: Current state and perspectives. Appl. Microbiol. Biotechnol. 2020, 104, 907-914. [CrossRef]

21. Butcher, D.J. Review: Recent advances in optical analytical atomic spectrometry. Appl. Spectrosc. Rev. 2013, 48, 261-328. [CrossRef]

22. Zou, Z.; Deng, Y.; Hu, J.; Jiang, X.; Hou, X. Recent trends in atomic fluorescence spectrometry towards miniaturized instrumentation-A review. Anal. Chim. Acta 2018, 1019, 25-37. [CrossRef] [PubMed]

23. Carter, S.; Clough, R.; Fisher, A.; Gibson, B.; Russell, B.; Waack, J. Atomic spectrometry update: Review of advances in the analysis of metals, chemicals and materials. J. Anal. At. Spectrom. 2020, 35, 2410-2474. [CrossRef]

24. Wang, L.; Peng, X.; Fu, H.; Huang, C.; Li, Y.; Liu, Z. Recent advances in the development of electrochemical aptasensors for detection of heavy metals in food. Biosens. Bioelectron. 2020, 147, 111777. [CrossRef]

25. Domínguez-Renedo, O.; Alonso-Lomillo, M.A.; Arcos-Martínez, M.J. Determination of metals based on electrochemical biosensors. Crit. Rev. Environ. Sci. Technol. 2013, 43, 1042-1073. [CrossRef]

26. Ma, S.; Zhang, Q.; Wu, D.; Hu, Y.; Hu, D.; Guo, Z.; Wang, S.; Liu, Q.; Peng, J. Unique G4-nanowires-mediated switch-modulated electrochemical biosensing for sensitive detection of nickel ion and histidine. J. Electroanal. Chem. 2019, 847, 113144. [CrossRef]

27. Rapini, R.; Canfarotta, F.; Mazzotta, E.; Malitesta, C.; Marrazza, G.; Piletsky, S.; Piletska, E. NanoMIP-based approach for the suppression of interference signals in electrochemical sensors. Analyst 2019, 144, 7290-7295. [CrossRef] [PubMed]

28. Wen, Y.; Li, F.Y.; Dong, X.; Zhang, J.; Xiong, Q.; Chen, P. The Electrical Detection of Lead Ions Using Gold-Nanoparticle- and DNAzyme-Functionalized Graphene Device. Adv. Healthc. Mater. 2013, 2, 271-274. [CrossRef]

29. Grygo-Szymanko, E.; Tobiasz, A.; Walas, S. Speciation analysis and fractionation of manganese: A review. TrAC Trends Anal. Chem. 2016, 80, 112-124. [CrossRef]

30. Cámara-Martos, F.; Da Costa, J.; Justino, C.I.L.; Cardoso, S.; Duarte, A.C.; Rocha-Santos, T. Disposable biosensor for detection of Iron(III) in wines. Talanta 2016, 154, 80-84. [CrossRef]

31. Punekar, N.S. Enzymes: Catalysis, Kinetics and Mechanisms; Springer Nature: Singapore, 2018. 
32. EFSA Panel on Dietetic Products, Nutrition and Allergies (NDA). Scientific Opinion on Dietary Reference Values for Calcium. EFSA J. 2015, 13, 4101. [CrossRef]

33. Bieleski, R.L. Phosphate Pools, Phosphate Transport, and Phosphate Availability. Annu. Rev. Plant Physiol. 1973, $24,225-252$. [CrossRef]

34. EFSA Panel on Dietetic Products, Nutrition and Allergies (NDA). Scientific opinion on dietary reference values for chromium. EFSA J. 2014, 12, 3845. [CrossRef]

35. WHO. WHO Guidelines for Drinking Water Quality, 4th ed.; World Health Organization: Geneva, Switzerland, 2011.

36. Taghdisi, S.M.; Danesh, N.M.; Lavaee, P.; Ramezani, M.; Abnous, K. An electrochemical aptasensor based on gold nanoparticles, thionine and hairpin structure of complementary strand of aptamer for ultrasensitive detection of lead. Sens. Actuators B Chem. 2016, 234, 462-469. [CrossRef]

37. Ma, R.N.; Wang, L.L.; Zhang, M.; Jia, L.P.; Zhang, W.; Shang, L.; Jia, W.L.; Wang, H.S. A novel one-step triggered "signal-on/off" electrochemical sensing platform for lead based on the dual-signal ratiometric output and electrode-bound DNAzyme assembly. Sens. Actuators B Chem. 2018, 257, 678-684. [CrossRef]

38. Yu, Y.; Wang, P.; Zhu, X.; Peng, Q.; Zhou, Y.; Yin, T.; Liang, Y.; Yin, X. Combined determination of copper ions and $\beta$-amyloid peptide by a single ratiometric electrochemical biosensor. Analyst 2018, 143, 323-331. [CrossRef] [PubMed]

39. Wustoni, S.; Hideshima, S.; Kuroiwa, S.; Nakanishi, T.; Mori, Y.; Osaka, T. Label-free detection of Cu(II) in a human serum sample by using a prion protein-immobilized FET sensor. Analyst 2015, 140, 6485-6488. [CrossRef]

40. Shi, L.; Wang, Y.; Ding, S.; Chu, Z.; Yin, Y.; Jiang, D.; Luo, J.; Jin, W. A facile and green strategy for preparing newly-designed 3D graphene/gold film and its application in highly efficient electrochemical mercury assay. Biosens. Bioelectron. 2017, 89, 871-879. [CrossRef] [PubMed]

41. Xiong, E.; Wu, L.; Zhou, J.; Yu, P.; Zhang, X.; Chen, J. A ratiometric electrochemical biosensor for sensitive detection of $\mathrm{Hg}^{2+}$ based on thymine- $\mathrm{Hg}^{2+}$-thymine structure. Anal. Chim. Acta 2015, 853, 242-248. [CrossRef]

42. Gao, X.; Huang, H.; Niu, S.; Ye, H.; Lin, Z.; Qiu, B.; Chen, G. Determination of magnesium ion in serum samples by a DNAzyme-based electrochemical biosensor. Anal. Methods 2012, 4, 947-952. [CrossRef]

43. Nie, J.; He, B.; Zang, Y.; Yin, W.; Han, L.; Li, W.; Hou, C.; Huo, D.; Yang, M.; Fa, H. A multi-functional minimally-disruptive portable electrochemical system based on yeast/ $\mathrm{Co}_{3} \mathrm{O}_{4} / \mathrm{Au} / \mathrm{SPEs}$ for blood lead(II) measurement. Bioelectrochemistry 2019, 126, 156-162. [CrossRef]

44. Taghdisi, S.M.; Danesh, N.M.; Ramezani, M.; Alibolandi, M.; Abnous, K. Voltammetric determination of lead(II) by using exonuclease III and gold nanoparticles, and by exploiting the conformational change of the complementary strand of an aptamer Microchim. Acta 2017, 184, 2783-2790. [CrossRef]

45. Liao, X.; Luo, J.; Wu, J.; Fan, T.; Yao, Y.; Gao, F.; Qian, Y. A sensitive DNAzyme-based electrochemical sensor for Pb ${ }^{2+}$ detection with platinum nanoparticles decorated $\mathrm{TiO}_{2} / \alpha-\mathrm{Fe}_{2} \mathrm{O}_{3}$ nanocomposite as signal labels. J. Electroanal. Chem. 2018, 829, 129-137. [CrossRef]

46. Wang, X.; Gao, W.; Yan, W.; Li, P.; Zou, H.; Wei, Z.; Guan, W.; Ma, Y.; Wu, S.; Yu, Y.; et al. A Novel Aptasensor Based on Graphene/Graphite Carbon Nitride Nanocomposites for Cadmium Detection with High Selectivity and Sensitivity. ACS Appl. Nano Mater. 2018, 1, 2341-2346. [CrossRef]

47. Wang, N.; Dai, H.; Wang, D.; Ma, H.; Lin, M. Determination of copper ions using a phytic acid/polypyrrole nanowires modified glassy carbon electrode. Mater. Sci. Eng. C 2017, 76, 139-143. [CrossRef]

48. Shi, Y.; Wang, H.; Jiang, X.; Sun, B.; Song, B.; Su, Y.; He, Y. Ultrasensitive, Specific, Recyclable, and Reproducible Detection of Lead Ions in Real Systems through a Polyadenine-Assisted, Surface-Enhanced Raman Scattering Silicon Chip. Anal. Chem. 2016, 88, 3723-3729. [CrossRef]

49. Chay, T.C.; Surif, S.; Heng, L.Y. A copper toxicity biosensor using immobilized cyanobacteria, Anabaena torulosa. Sens. Lett. 2005, 3, 49-54. [CrossRef]

50. Adekunle, A.; Rickwood, C.; Tartakovsky, B. Online monitoring of heavy metal-related toxicity using flow-through and floating microbial fuel cell biosensors. Environ. Monit. Assess. 2020, 192. [CrossRef]

51. Jiang, Y.; Chen, X.; Lan, L.; Pan, Y.; Zhu, G.; Miao, P. Gly-Gly-His tripeptide- and silver nanoparticle-assisted electrochemical evaluation of copper(II) ions in aqueous environment. New J. Chem. 2018, 42, 14733-14737. [CrossRef]

52. Wang, G.H.; Cheng, C.Y.; Liu, M.H.; Chen, T.Y.; Hsieh, M.C.; Chung, Y.C. Utility of Ochrobactrum anthropi yc152 in a microbial fuel cell as an early warning device for hexavalent chromium determination. Sensors 2016, 16, 1272. [CrossRef]

53. Nepomuscene, N.J.; Daniel, D.; Krastanov, A. Biosensor to detect chromium in wastewater. Biotechnol. Biotechnol. Equip. 2007, 21, 377-381. [CrossRef]

54. Mandl, M.; Macholán, L. Membrane biosensor for the determination of iron(II, III) based on immobilized cells of Thiobacillus ferrooxidans. Folia Microbiol. 1990, 35, 363-367. [CrossRef]

55. Singh, J.; Mittal, S.K. A new assembly for biosensing ultra-trace levels of mercury in a continuous flow system. Anal. Methods 2014, 6, 5741-5745. [CrossRef]

56. Verma, N.; Singh, M. A Bacillus sphaericus based biosensor for monitoring nickel ions in industrial effluents and foods. J. Autom. Methods Manag. Chem. 2006, 2006, 083427. [CrossRef] [PubMed]

57. Rocha, D.L.; Batista, A.D.; Rocha, F.R.P.; Donati, G.L.; Nóbrega, J.A. Greening sample preparation in inorganic analysis. TrAC Trends Anal. Chem. 2013, 45, 79-92. [CrossRef] 
58. Isarankura-Na-Ayudhya, C.; Tantimongcolwat, T.; Galla, H.J.; Prachayasit-tikul, V. Fluorescent protein-based optical biosensor for copper ion quantitation. Biol. Trace Elem. Res. 2010, 134, 352-363. [CrossRef]

59. Fang, X.; Zhao, Q.; Cao, H.; Liu, J.; Guan, M.; Kong, J. Rapid detection of $\mathrm{Cu}^{2+}$ by a paper-based microfluidic device coated with bovine serum albumin (BSA)—Au nanoclusters. Analyst 2015, 140, 7823-7826. [CrossRef]

60. Tantimongcolwat, T.; Isarankura-Na-Ayudhya, C.; Srisarin, A.; Galla, H.J.; Prachayasittikul, V. Polyacrylamide hydrogel encapsulated E. coli expressing metal-sensing green fluorescent protein as a potential tool for copper ion determination. EXCLI J. 2014, 13, 401-415. [CrossRef]

61. Lam, C.K.S.C.C.; Jickells, T.D.; Richardson, D.J.; Russell, D.A. Fluorescence-based siderophore biosensor for the determination of bioavailable iron in oceanic waters. Anal. Chem. 2006, 78, 5040-5045. [CrossRef]

62. Marieeswaran, M.; Panneerselvam, P. Fluorescent Polyaniline Nanoclips (PANCs): A Highly Sensitive and Selective Chemical Sensor for the Detection of $\mathrm{Hg}(\mathrm{II})$ Ions in Aqueous Media. ChemistrySelect 2020, 5, 4481-4487. [CrossRef]

63. Teh, H.B.; Li, H.; Yau Li, S.F. Highly sensitive and selective detection of $\mathrm{Pb}^{2+}$ ions using a novel and simple DNAzyme-based quartz crystal microbalance with dissipation biosensor. Analyst 2014, 139, 5170-5175. [CrossRef]

64. May, L.M.; Russell, D.A. Novel determination of cadmium ions using an enzyme self-assembled monolayer with surface plasmon resonance. Anal. Chim. Acta 2003, 500, 119-125. [CrossRef]

65. Cennamo, N.; Alberti, G.; Pesavento, M.; D’Agostino, G.; Quattrini, F.; Biesuz, R.; Zeni, L. A simple small size and low cost sensor based on Surface Plasmon Resonance for selective detection of Fe(III). Sensors 2014, 14, 4657-4671. [CrossRef] [PubMed]

66. Shervedani, R.K.; Akrami, Z. Gold-deferrioxamine nanometric interface for selective recognition of Fe(III) using square wave voltammetry and electro-chemical impedance spectroscopy methods. Biosens. Bioelectron. 2013, 39, 31-36. [CrossRef] [PubMed]

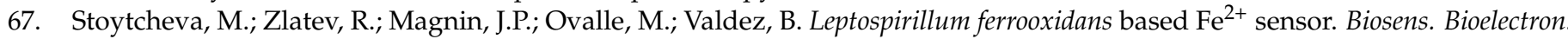
2009, 25, 482-487. [CrossRef] [PubMed]

68. Zlatev, R.; Magnin, J.P.; Ozil, P.; Stoytcheva, M. Bacterial sensors based on Acidithiobacillus ferrooxidans: $\mathrm{Part}_{\mathrm{I}}$. Fe ${ }^{2+}$ and $\mathrm{S}_{2} \mathrm{O}_{3}{ }^{2-}$ determination. Biosens. Bioelectron. 2006, 21, 1493-1500. [CrossRef] [PubMed]

69. Torrinha, Á.; Montenegro, M.C.B.S.M.; Araújo, A.N. Microfluidic Platform with an Embedded Pencil Graphite Electrode Biosensor for the Detection of Glucose and Cadmium. J. Electrochem. Soc. 2019, 166, B155-B160. [CrossRef]

70. Lin, M.; Hu, X.; Ma, Z.; Chen, L. Functionalized polypyrrole nanotube arrays as electrochemical biosensor for the determination of copper ions. Anal. Chim. Acta 2012, 746, 63-69. [CrossRef]

71. Gao, F.; Gao, C.; He, S.; Wang, Q.; Wu, A. Label-free electrochemical lead(II) aptasensor using thionine as the signaling molecule and graphene as signal-enhancing platform. Biosens. Bioelectron. 2016, 81, 15-22. [CrossRef]

72. Liu, S.; Kang, M.; Yan, F.; Peng, D.; Yang, Y.; He, L.; Wang, M.; Fang, S.; Zhang, Z. Electrochemical DNA biosensor based on microspheres of cuprous oxide and nano-chitosan for $\mathrm{Hg}$ (II) detection. Electrochim. Acta 2015, 160, 64-73. [CrossRef]

73. Tang, L.; Xie, X.; Zhou, Y.; Zeng, G.; Tang, J.; Wu, Y.; Long, B.; Peng, B.; Zhu, J. A reusable electrochemical biosensor for highly sensitive detection of mercury ions with an anionic intercalator supported on ordered mesoporous carbon/self-doped polyaniline nanofibers platform. Biochem. Eng. J. 2017, 117, 7-14. [CrossRef]

74. Kaleli-Can, G.; Ozlu, B.; Özgüzar, H.F.; Onal-Ulusoy, B.; Kabay, G.; Eom, T.; Shim, B.S.; Mutlu, M. Natural Melanin Nanoparticledecorated Screen-printed Carbon Electrode: Performance Test for Amperometric Determination of Hexavalent Chromium as Model Trace. Electroanalysis 2020, 32, 1696-1706. [CrossRef]

75. Norocel, L.; Gutt, G. Screen-printed voltammetric biosensors for the determination of copper in wine. Sensors 2019, 19 , 4618. [CrossRef] [PubMed]

76. Liana, D.D.; Raguse, B.; Wieczorek, L.; Baxter, G.R.; Chuah, K.; Gooding, J.J.; Chow, E. Sintered gold nanoparticles as an electrode material for paper-based electrochemical sensors. RSC Adv. 2013, 3, 8683-8691. [CrossRef]

77. Norocel, L.; Gutt, G. Method and electrochemical biosensor for detection of copper in wine. Rev. Chim. 2018, 69, 3010-3012. [CrossRef]

78. Zhou, J.; Huang, H.; Chen, S.; Wang, M.; Zhao, D.; Yu, J.; Jin, S.; Zhong, Y.; Chen, X.; Yu, X.; et al. A high sensitive chemiresistivebiosensor based on self-assembly grown GaN porous layer. Sens. Actuators B Chem. 2021, 345, 130360. [CrossRef]

79. Yang, S.; Liu, P.; Wang, Y.; Guo, Z.; Tan, R.; Qu, L. Electrochemical sensor using poly-(l-cysteine) functionalized CuO nanoneedles/N-doped reduced graphene oxide for detection of lead ions. RSC Adv. 2020, 10, 18526-18532. [CrossRef]

80. Wu, X.; Liu, W.; Dai, H.; Chen, G. A novel sensitive biosensor for $\mathrm{Ca}^{2+}$ based on electropolymerized melatonin modified electrode. Electrochem. Commun. 2009, 11, 393-396. [CrossRef]

81. Akbari Hasanjani, H.R.; Zarei, K. An electrochemical sensor for attomolar determination of mercury(II) using DNA/poly-Lmethionine-gold nanoparticles/pencil graphite electrode. Biosens. Bioelectron. 2019, 128, 1-8. [CrossRef]

82. Chen, G.; Bai, W.; Jin, Y.; Zheng, J. Fluorescence and electrochemical assay for bimodal detection of lead ions based on MetalOrganic framework nanosheets. Talanta 2021, 232, 122405. [CrossRef]

83. Weng, C.; Li, X.; Lu, Q.; Yang, W.; Wang, J.; Yan, X.; Li, B.; Sakran, M.; Hong, J.; Zhu, W.; et al. A label-free electrochemical biosensor based on magnetic biocomposites with DNAzyme and hybridization chain reaction dual signal amplification for the determination of $\mathrm{Pb}^{2+}$. Microchim. Acta 2020, 187, 575. [CrossRef]

84. Bi, X.; Wong, W.L.; Ji, W.; Agarwal, A.; Balasubramanian, N.; Yang, K.L. Development of electrochemical calcium sensors by using silicon nanowires modified with phosphotyrosine. Biosens. Bioelectron. 2008, 23, 1442-1448. [CrossRef] [PubMed] 
85. Rabai, S.; Benounis, M.; Catanante, G.; Baraket, A.; Errachid, A.; Jaffrezic Renault, N.; Marty, J.L.; Rhouati, A. Development of a label-free electrochemical aptasensor based on diazonium electrodeposition: Application to cadmium detection in water. Anal. Biochem. 2021, 612, 113956. [CrossRef]

86. Niu, Y.; Chen, Y.; Zhang, X.; Xie, H.; Luo, G.; Sun, W. Target-enhanced photoelectrochemical aptasensor for Cd(II) detection using graphite-like carbon nitride as sensitizer with high sensitivity. Microchem. J. 2021, 168, 106394. [CrossRef]

87. Yu, Y.; Yu, C.; Yin, T.; Ou, S.; Sun, X.; Wen, X.; Zhang, L.; Tang, D.; Yin, X. Functionalized poly(ionic liquid) as the support to construct a ratiometric electrochemical biosensor for the selective determination of copper ions in AD rats. Biosens. Bioelectron. 2017, 87, 278-284. [CrossRef] [PubMed]

88. Oztekin, Y.; Yazicigil, Z.; Ramanaviciene, A.; Ramanavicius, A. Polyphenol-modified glassy carbon electrodes for copper detection. Sens. Actuators B Chem. 2011, 152, 37-48. [CrossRef]

89. Yüce, M.; Nazir, H.; Dönmez, G. A voltammetric Rhodotorula mucilaginosa modified microbial biosensor for Cu(II) determination. Bioelectrochemistry 2010, 79, 66-70. [CrossRef]

90. Alpat, S.K.; Alpat, Ş.; Kutlu, B.; Özbayrak, Ö.; Büyükişik, H.B. Development of biosorption-based algal biosensor for Cu(II) using Tetraselmis chuii. Sens. Actuators B Chem. 2007, 128, 273-278. [CrossRef]

91. Gu, H.; Hou, Q.; Liu, Y.; Cai, Y.; Guo, Y.; Xiang, H.; Chen, S. On-line regeneration of electrochemical biosensor for in vivo repetitive measurements of striatum $\mathrm{Cu}^{2+}$ under global cerebral ischemia/reperfusion events. Biosens. Bioelectron. 2019, 135, 111-119. [CrossRef]

92. Atapour, M.; Amoabediny, G.; Ahmadzadeh-Raji, M. Integrated optical and electrochemical detection of $\mathrm{Cu}^{2+}$ ions in water using a sandwich amino acid-gold nanoparticle-based nano-biosensor consisting of a transparent-conductive platform. RSC Adv. 2019, 9, 8882-8893. [CrossRef]

93. Wawrzyniak, U.E.; Ciosek, P.; Zaborowski, M.; Liu, G.; Gooding, J.J. Gly-Gly-His immobilized on monolayer modified back-side contact miniaturized sensors for complexation of copper ions. Electroanalysis 2013, 25, 1461-1471. [CrossRef]

94. Amin, N.U.; Kun-Lin, Y.; Majeed, N.; Siddiqi, H.M. Fabrication of a Fluorophore/Liquid-Crystal-Based Oligopeptide Biosensor for the Detection of $\mathrm{Cu}(\mathrm{II})$ Ions. ChemistrySelect 2021, 6, 6607-6618. [CrossRef]

95. Singh, V.K.; Kushwaha, C.S.; Shukla, S.K. Potentiometric detection of copper ion using chitin grafted polyaniline electrode. Int. J. Biol. Macromol. 2020, 147, 250-257. [CrossRef] [PubMed]

96. Ezhil-Vilian, A.T.; Shahzad, A.; Chung, J.; Choe, S.R.; Kim, W.S.; Huh, Y.S.; Yu, T.; Han, Y.K. Square voltammetric sensing of mercury at very low working potential by using oligomer-functionalized Ag@Au core-shell nanoparticles. Microchim. Acta 2017, 184, 3547-3556. [CrossRef]

97. Bala, A.; Górski, Ł. Determination of mercury cation using electrode modified with phosphorothioate oligonucleotide. Sens. Actuators B Chem. 2016, 230, 731-735. [CrossRef]

98. Wang, N.; Lin, M.; Dai, H.; Ma, H. Functionalized gold nanoparticles/reduced graphene oxide nanocomposites for ultrasensitive electrochemical sensing of mercury ions based on thymine-mercury-thymine structure. Biosens. Bioelectron. 2016, 79, 320-326. [CrossRef]

99. An, J.H.; Park, S.J.; Kwon, O.S.; Bae, J.; Jang, J. High-performance flexible graphene aptasensor for mercury detection in mussels. ACS Nano 2013, 7, 10563-10571. [CrossRef]

100. Lü, H.; Zhao, Y.; Ma, J.; Li, J.; Wang, H.; Lu, Z. Electrochemical detection of magnesium ions using PVC membrane trapped chlorophyll A molecules. Mol. Cryst. Liq. Cryst. Sci. Technol. Sect. A Mol. Cryst. Liq. Cryst. 2001, 371, 391-396. [CrossRef]

101. Liu, H.; Wang, J.; Jin, H.; Wei, M.; Ren, W.; Zhang, Y.; Wu, L.; He, B. Electrochemical biosensor for sensitive detection of $\mathrm{Hg}^{2+}$ baesd on clustered peonylike copper-based metal-organic frameworks and DNAzyme-driven DNA Walker dual amplification signal strategy. Sens. Actuators B Chem. 2021, 329, 129215. [CrossRef]

102. Ding, J.; Liu, Y.; Zhang, D.; Yu, M.; Zhan, X.; Zhang, D.; Zhou, P. An electrochemical aptasensor based on gold@polypyrrole composites for detection of lead ions. Microchim. Acta 2018, 185, 545. [CrossRef]

103. Gil, R.L.; Amorim, C.G.; Montenegro, M.C.B.S.M.; Araújo, A.N. Potentiometric detection in liquid chromatographic systems: An overview. J. Chromatogr. A 2019, 1602, 326-340. [CrossRef]

104. Chandra, S.; Dhawangale, A.; Mukherji, S. Hand-held optical sensor using denatured antibody coated electroactive polymer for ultra-trace detection of copper in blood serum and environmental samples. Biosens. Bioelectron. 2018, 110, 38-43. [CrossRef] [PubMed]

105. Zhang, L.; Chang, H.; Hirata, A.; Wu, H.; Xue, Q.K.; Chen, M. Nanoporous gold based optical sensor for sub-ppt detection of mercury ions. ACS Nano 2013, 7, 4595-4600. [CrossRef] [PubMed]

106. Akyilmaz, E.; Kozgus, O. Determination of calcium in milk and water samples by using catalase enzyme electrode. Food Chem. 2009, 115, 347-351. [CrossRef]

107. Moyo, M.; Okonkwo, J.O. Horseradish peroxidase biosensor based on maize tassel-MWCNTs composite for cadmium detection. Sens. Actuators B Chem. 2014, 193, 515-521. [CrossRef]

108. Shtenberg, G.; Massad-Ivanir, N.; Segal, E. Detection of trace heavy metal ions in water by nanostructured porous Si biosensors. Analyst 2015, 140, 4507-4514. [CrossRef]

109. Vopálenská, I.; Váchová, L.; Palková, Z. New biosensor for detection of copper ions in water based on immobilized genetically modified yeast cells. Biosens. Bioelectron. 2015, 72, 160-167. [CrossRef] 
110. Ballen, S.C.; Ostrowski, G.M.; Steffens, J.; Steffens, C. Graphene Oxide/Urease Nanobiosensor Applied for Cadmium Detection in River Water. IEEE Sens. J. 2021, 21, 9626-9633. [CrossRef]

111. Swain, K.K.; Bhand, S. A colorimetric paper-based ATONP-ALP nanobiosensor for selective detection of $\mathrm{Cd}^{2+}$ ions in clams and mussels. Anal. Bioanal. Chem. 2021, 413, 1715-1727. [CrossRef]

112. Dabhade, A.; Jayaraman, S.; Paramasivan, B. Development of glucose oxidase-chitosan immobilized paper biosensor using screen-printed electrode for amperometric detection of $\mathrm{Cr}(\mathrm{VI})$ in water. 3 Biotech 2021, 11, 183. [CrossRef]

113. Attar, A.; Emilia Ghica, M.; Amine, A.; Brett, C.M.A. Poly(neutral red) based hydrogen peroxide biosensor for chromium determination by inhibition measurements. J. Hazard. Mater. 2014, 279, 348-355. [CrossRef]

114. Kaur, G.; Verma, N. Colorimetric determination of $\mathrm{Cu}^{2+}$ ions in water and milk by apotyrosinase disc. Sens. Actuators B Chem. 2018, 263, 524-532. [CrossRef]

115. Elsebai, B.; Ghica, M.E.; Abbas, M.N.; Brett, C.M.A. Catalase based hydrogen peroxide biosensor for mercury determination by inhibition measurements. J. Hazard. Mater. 2017, 340, 344-350. [CrossRef]

116. Smit, M.H.; Rechnitz, G.A. Reagentless Enzyme Electrode for the Determination of Manganese through Biocatalytic Enhancement. Anal. Chem. 1992, 64, 245-249. [CrossRef] [PubMed]

117. Magar, H.S.; Ghica, M.E.; Abbas, M.N.; Brett, C.M.A. Highly Sensitive Choline Oxidase Enzyme Inhibition Biosensor for Lead Ions Based on Multiwalled Carbon Nanotube Modified Glassy Carbon Electrodes. Electroanalysis 2017, 29, 1741-1748. [CrossRef]

118. Sabir, S.; Akash, M.S.H.; Fiayyaz, F.; Saleem, U.; Mehmood, M.H.; Rehman, K. Role of cadmium and arsenic as endocrine disruptors in the metabolism of carbohydrates: Inserting the association into perspectives. Biomed. Pharmacother. 2019, 114, 108802. [CrossRef]

119. Liu, S.; Wei, W.; Sun, X.; Wang, L. Ultrasensitive electrochemical DNAzyme sensor for lead ion based on cleavage-induced template-independent polymerization and alkaline phosphatase amplification. Biosens. Bioelectron. 2016, 83, 33-38. [CrossRef] [PubMed]

120. Tan, Y.C.; Kharkwal, S.; Chew, K.K.W.; Alwi, R.; Mak, S.F.W.; Ng, H.Y. Enhancing the robustness of microbial fuel cell sensor for continuous copper(II) detection against organic strength fluctuations by acetate and glucose addition. Bioresour. Technol. 2018, 259, 357-364. [CrossRef]

121. Yu, D.; Bai, L.; Zhai, J.; Wang, Y.; Dong, S. Toxicity detection in water containing heavy metal ions with a self-powered microbial fuel cell-based biosensor. Talanta 2017, 168, 210-216. [CrossRef]

122. Wang, D.; Liang, P.; Jiang, Y.; Liu, P.; Miao, B.; Hao, W.; Huang, X. Open external circuit for microbial fuel cell sensor to monitor the nitrate in aquatic environment. Biosens. Bioelectron. 2018, 111, 97-101. [CrossRef]

123. Xu, Z.; Liu, B.; Dong, Q.; Lei, Y.; Li, Y.; Ren, J.; McCutcheon, J.; Li, B. Flat microliter membrane-based microbial fuel cell as “on-line sticker sensor" for self-supported in situ monitoring of wastewater shocks. Bioresour. Technol. 2015, 197, 244-251. [CrossRef]

124. Zhang, J.; Shi, P.; Yan, P.; Wang, M.; Tang, Q.; Deng, A.; Li, J. Quantum Dots Based Electrochemiluminescent Immunosensor for Ultrasensitive and Specific Determination of Mercury(II) Ions Using Gold Nanoparticles and a Monoclonal Antibody. J. Electrochem. Soc. 2015, 162, B22-B26. [CrossRef]

125. Wang, H.; Luo, Q.; Zhao, Y.; Nan, X.; Zhang, F.; Wang, Y.; Wang, Y.; Hua, D.; Zheng, S.; Jiang, L.; et al. Electrochemical device based on nonspecific DNAzyme for the high-accuracy determination of $\mathrm{Ca}^{2+}$ with $\mathrm{Pb}^{2+}$ interference. Bioelectrochemistry 2021, 140, 107732. [CrossRef]

126. Ebrahimi, M.; Raoof, J.B.; Ojani, R. Design of an electrochemical DNA-based biosensor for selective determination of cadmium ions using a DNA hybridization indicator. Int. J. Biol. Macromol. 2018, 108, 1237-1241. [CrossRef] [PubMed]

127. Qu, J.; Wu, L.; Liu, H.; Li, J.; Lv, H.; Fu, X.; Song, Y. A novel electrochemical biosensor based on DNA for rapid and selective detection of cadmium. Int. J. Electrochem. Sci. 2015, 10, 4020-4028.

128. Sreekanth, S.P.; Alodhayb, A.; Assaifan, A.K.; Alzahrani, K.E.; Muthuramamoorthy, M.; Alkhammash, H.I.; Pandiaraj, S.; Alswieleh, A.M.; Van Le, Q.; Mangaiyarkarasi, R.; et al. Multi-walled carbon nanotube-based nanobiosensor for the detection of cadmium in water. Environ. Res. 2021, 197, 111148. [CrossRef]

129. Wang, H.; Zheng, S.; Nan, X.; Zhao, Y.; Wang, Y.; Zhang, F.; Yang, L.; Lixing, X.; Xiong, B. Non-specific DNAzyme-based biosensor with interfering ions for the $\mathrm{Cd}^{2+}$ determination in feed. Sens. Actuators B Chem. 2021, 329, 129139. [CrossRef]

130. Ocaña, C.; Malashikhina, N.; Del Valle, M.; Pavlov, V. Label-free selective impedimetric detection of $\mathrm{Cu}^{2+}$ ions using catalytic DNA. Analyst 2013, 138, 1995-1999. [CrossRef] [PubMed]

131. Xu, S.; Dai, B.; Xu, J.; Jiang, L.; Huang, H. An Electrochemical Sensor for the Detection of Cu ${ }^{2+}$ Based on Gold Nanoflowersmodifed Electrode and DNAzyme Functionalized Au@MIL-101 (Fe). Electroanalysis 2019, 31, 2330-2338. [CrossRef]

132. Tian, R.; Chen, X.; Liu, D.; Yao, C. A Sensitive Biosensor for Determination of $\mathrm{Cu}^{2+}$ by One-step Electrodeposition. Electroanalysis 2016, 28, 1617-1624. [CrossRef]

133. Hu, W.; Min, X.; Li, X.; Yang, S.; Yi, L.; Chai, L. DNAzyme catalytic beacons-based a label-free biosensor for copper using electrochemical impedance spectroscopy. RSC Adv. 2016, 6, 6679-6685. [CrossRef]

134. Tang, D.; Zhang, J.; Tang, Y.; Teng, L.; Xia, B.; Tang, D. Hairpin DNA-Dependent Click Conjugation of Oligonucleotides for Electrochemical Monitoring of Copper(II). Electroanalysis 2015, 27, 2513-2517. [CrossRef]

135. Zhang, Y.; Chu, G.; Guo, Y.; Zhao, W.; Yang, Q.; Sun, X. An electrochemical biosensor based on Au nanoparticles decorated reduced graphene oxide for sensitively detecting of $\mathrm{Hg}^{2+}$. J. Electroanal. Chem. 2018, 824, 201-206. [CrossRef] 
136. Zhang, Y.; Zhang, C.; Ma, R.; Du, X.; Dong, W.; Chen, Y.; Chen, Q. An ultra-sensitive Au nanoparticles functionalized DNA biosensor for electrochemical sensing of mercury ions. Mater. Sci. Eng. C 2017, 75, 175-181. [CrossRef] [PubMed]

137. Tang, J.; Huang, Y.; Zhang, C.; Liu, H.; Tang, D. DNA-based electrochemical determination of mercury(II) by exploiting the catalytic formation of gold amalgam and of silver nanoparticles. Microchim. Acta 2016, 183, 1805-1812. [CrossRef]

138. Ebrahimi, M.; Raoof, J.B.; Ojani, R.; Bagheryan, Z. A novel electrochemical biosensor for selective determination of mercury ions based on DNA hybridization. Anal. Biochem. 2015, 488, 12-13. [CrossRef] [PubMed]

139. He, L.L.; Cheng, L.; Lin, Y.; Cui, H.F.; Hong, N.; Peng, H.; Kong, D.R.; Chen, C.D.; Zhang, J.; Wei, G.; et al. A sensitive biosensor for mercury ions detection based on hairpin hindrance by thymine-Hg(II)-thymine structure. J. Electroanal. Chem. 2018, 814, 161-167. [CrossRef]

140. Ziółkowski, R.; Jarczewska, M.; Górski, Ł.; Malinowska, E. Oligonucleotide-Based Electrochemical Biosensor for Hg ${ }^{2+} \mathrm{Using}$ Methylene Blue as a Redox Indicator. J. Electrochem. Soc. 2013, 160, B152-B155. [CrossRef]

141. Zhang, Y.; Zhao, H.; Wu, Z.; Xue, Y.; Zhang, X.; He, Y.; Li, X.; Yuan, Z. A novel graphene-DNA biosensor for selective detection of mercury ions. Biosens. Bioelectron. 2013, 48, 180-187. [CrossRef]

142. Qiu, Z.; Tang, D.; Shu, J.; Chen, G.; Tang, D. Enzyme-triggered formation of enzyme-tyramine concatamers on nanogoldfunctionalized dendrimer for impedimetric detection of $\mathrm{Hg}(\mathrm{II})$ with sensitivity enhancement. Biosens. Bioelectron. 2016, 75, 108-115. [CrossRef]

143. Huang, Y.L.; Gao, Z.F.; Jia, J.; Luo, H.Q.; Li, N.B. A label-free electrochemical sensor for detection of Mercury(II) ions based on the direct growth of guanine nanowire. J. Hazard. Mater. 2016, 308, 173-178. [CrossRef]

144. Tortolini, C.; Bollella, P.; Antonelli, M.L.; Antiochia, R.; Mazzei, F.; Favero, G. DNA-based biosensors for $\mathrm{Hg}^{2+}$ determination by polythymine-methylene blue modified electrodes. Biosens. Bioelectron. 2015, 67, 524-531. [CrossRef]

145. He, Z.J.; Kang, T.F.; Lu, L.P.; Cheng, S.Y. An electrochemiluminescence sensor based on CdSe@CdS-functionalized MoS 2 and a GOD-labeled DNA probe for the sensitive detection of $\mathrm{Hg}(\mathrm{II})$. Anal. Methods 2020, 12, 491-498. [CrossRef]

146. Fan, X.; Wang, S.; Li, Z.; Wang, Y.; Fan, X.; Yu, L. An electrochemiluminescence biosensor for the determination of mercury ion via dual-amplification strategy. J. Braz. Chem. Soc. 2020, 31, 2620-2627. [CrossRef]

147. Duan, Y.; Wang, F.; Zhang, X.; Liu, Q.; Lu, M.; Ji, W.; Zhang, Y.; Jing, Z.; Peng, W. TFBG-SPR DNA-Biosensor for Renewable Ultra-Trace Detection of Mercury Ions. J. Lightwave Technol. 2021, 39, 3903-3910. [CrossRef]

148. He, W.; Qiao, B.; Li, F.; Pan, L.; Chen, D.; Cao, Y.; Tu, J.; Wang, X.; Lv, C.; Wu, Q. A novel electrochemical biosensor for ultrasensitive $\mathrm{Hg}^{2+}$ detection: Via a triple signal amplification strategy. Chem. Commun. 2021, 57, 619-622. [CrossRef] [PubMed]

149. Li, L.; Chen, B.; Luo, L.; Liu, X.; Bi, X.; You, T. Sensitive and selective detection of $\mathrm{Hg}^{2+}$ in tap and canal water via self-enhanced ECL aptasensor based on $\mathrm{NH}_{2}-\mathrm{Ru} @ S i O_{2}-\mathrm{NGQDs}$. Talanta 2021, 222, 121579. [CrossRef]

150. De Acha, N.; Elosúa, C.; Arregui, F.J. Development of an aptamer based luminescent optical fiber sensor for the continuous monitoring of $\mathrm{Hg}^{2+}$ in Aqueous media. Sensors 2020, 20, 2372. [CrossRef] [PubMed]

151. Qing, M.; Chen, S.; Xie, S.; Tang, Y.; Zhang, J.; Yuan, R. Encapsulation and Release of Recognition Probes Based on a Rigid Three-Dimensional DNA “nanosafe-box" for Construction of a Electrochemical Biosensor. Anal. Chem. 2020, 92, $1811-1817$. [CrossRef]

152. Cao, S.P.; Hu, H.M.; Liang, R.P.; Qiu, J.D. An ultrasensitive electrochemiluminescence resonance energy transfer biosensor for divalent mercury monitoring. J. Electroanal. Chem. 2020, 856, 113494. [CrossRef]

153. Jarczewska, M.; Górski, Ł.; Malinowska, E. Application of DNA aptamers as sensing layers for electrochemical detection of potassium ions. Sens. Actuators B Chem. 2016, 226, 37-43. [CrossRef]

154. Li, L.D.; Huang, X.Q.; Guo, L. Electrochemical potassium ion sensor based on DNA G-quadruplex conformation and gold nanoparticle amplification. Rare Met. 2013, 32, 369-374. [CrossRef]

155. Chen, Z.; Zhou, T.; Zhang, C.; Ma, H.; Lin, Y.; Li, K. Aptasensor for label-free square-wave voltammetry detection of potassium ions based on gold nanoparticle amplification. RSC Adv. 2014, 4, 48671-48675. [CrossRef]

156. Chen, Z.; Chen, L.; Ma, H.; Zhou, T.; Li, X. Aptamer biosensor for label-free impedance spectroscopy detection of potassium ion based on DNA G-quadruplex conformation. Biosens. Bioelectron. 2013, 48, 108-112. [CrossRef] [PubMed]

157. Yang, Y.; Yuan, Z.; Liu, X.P.; Liu, Q.; Mao, C.J.; Niu, H.L.; Jin, B.K.; Zhang, S.Y. Electrochemical biosensor for Ni ${ }^{2+}$ detection based on a DNAzyme-CdSe nanocomposite. Biosens. Bioelectron. 2016, 77, 13-18. [CrossRef] [PubMed]

158. Ma, Y.; Yu, C.; Yu, Y.; Chen, J.; Gao, R.; He, J. DNAzyme assisted recycling amplification method for ultrasensitive amperometric determination of lead(II) based on the use of a hairpin assembly on a composite prepared from nitrogen doped graphene, perylenetetracarboxylic anhydride, thionine and gold nanoparticles. Microchim. Acta 2019, 186, 677. [CrossRef]

159. Xie, X.; Chai, Y.; Yuan, Y.; Yuan, R. Dual triggers induced disassembly of DNA polymer decorated silver nanoparticle for ultrasensitive electrochemical $\mathrm{Pb}^{2+}$ detection. Anal. Chim. Acta 2018, 1034, 56-62. [CrossRef] [PubMed]

160. Xiao, Q.; Feng, J.; Li, J.; Feng, M.; Huang, S. A label-free and ultrasensitive electrochemical aptasensor for lead(II) using a N,P dual-doped carbon dot-chitosan composite as a signal-enhancing platform and thionine as a signaling molecule. Analyst 2018, 143, 4764-4773. [CrossRef]

161. Yu, Y.; Yu, C.; Niu, Y.; Chen, J.; Zhao, Y.; Zhang, Y.; Gao, R.; He, J. Target triggered cleavage effect of DNAzyme: Relying on Pd-Pt alloys functionalized Fe-MOFs for amplified detection of $\mathrm{Pb}^{2+}$. Biosens. Bioelectron. 2018, 101, 297-303. [CrossRef]

162. Ebrahimi, M.; Raoof, J.B.; Ojani, R. Design of a novel electrochemical biosensor based on intramolecular G-quadruplex DNA for selective determination of lead(II) ions. Anal. Bioanal. Chem. 2017, 409, 4729-4739. [CrossRef] 
163. Yuan, M.; Song, Z.; Fei, J.; Wang, X.; Xu, F.; Cao, H.; Yu, J. Aptasensor for lead(II) based on the use of a quartz crystal microbalance modified with gold nanoparticles. Microchim. Acta 2017, 184, 1397-1403. [CrossRef]

164. Bala, A.; Pietrzak, M.; Górski, L.; Malinowska, E. Electrochemical determination of lead ion with DNA oligonucleotide-based biosensor using anionic redox marker. Electrochim. Acta 2015, 180, 763-769. [CrossRef]

165. Jarczewska, M.; Kierzkowska, E.; Ziółkowski, R.; Górski, Ł.; Malinowska, E. Electrochemical oligonucleotide-based biosensor for the determination of lead ion. Bioelectrochemistry 2015, 101, 35-41. [CrossRef] [PubMed]

166. Wu, Y.F.; Cai, Z.M.; Wu, G.H.; Rong, M.C.; Jiang, Y.Q.; Yang, C.Y.J.; Chen, X. A novel signal-on DNAzyme-based electrochemiluminescence sensor for $\mathrm{Pb}^{2+}$. Sens. Actuators B Chem. 2014, 191, 60-66. [CrossRef]

167. Lai, C.; Zhang, Y.; Liu, X.; Liu, S.; Li, B.; Zhang, M.; Qin, L.; Yi, H.; Li, M.; Li, L.; et al. Electrochemical biosensor for amplified detection of $\mathrm{Pb}^{2+}$ based on perfect match of reduced graphene oxide-gold nanoparticles and single-stranded DNAzyme. Anal. Bioanal. Chem. 2019, 411, 7499-7509. [CrossRef] [PubMed]

168. Zhou, Q.; Lin, Y.; Lin, Y.; Wei, Q.; Chen, G.; Tang, D. Highly sensitive electrochemical sensing platform for lead ion based on synergetic catalysis of DNAzyme and Au-Pd porous bimetallic nanostructures. Biosens. Bioelectron. 2016, 78, 236-243. [CrossRef] [PubMed]

169. Xue, S.; Jing, P.; Xu, W. Hemin on graphene nanosheets functionalized with flower-like $\mathrm{MnO}_{2}$ and hollow AuPd for the electrochemical sensing lead ion based on the specific DNAzyme. Biosens. Bioelectron. 2016, 86, 958-965. [CrossRef] [PubMed]

170. Wang, L.; Wen, Y.; Li, L.; Yang, X.; Jia, N.; Li, W.; Meng, J.; Duan, M.; Sun, X.; Liu, G. Sensitive and label-free electrochemical lead ion biosensor based on a DNAzyme triggered G-quadruplex/hemin conformation. Biosens. Bioelectron. 2018, 115, 91-96. [CrossRef]

171. Kuang, H.; Xing, C.; Hao, C.; Liu, L.; Wang, L.; Xu, C. Rapid and highly sensitive detection of lead ions in drinking water based on a strip immunosensor. Sensors 2013, 13, 4214-4224. [CrossRef]

172. Zhang, C.; Lai, C.; Zeng, G.; Huang, D.; Tang, L.; Yang, C.; Zhou, Y.; Qin, L.; Cheng, M. Nanoporous Au-based chronocoulometric aptasensor for amplified detection of $\mathrm{Pb}^{2+}$ using DNAzyme modified with Au nanoparticles. Biosens. Bioelectron. 2016, 81, 61-67. [CrossRef]

173. Tang, S.; Tong, P.; You, X.; Lu, W.; Chen, J.; Li, G.; Zhang, L. Label free electrochemical sensor for Pb ${ }^{2+}$ based on graphene oxide mediated deposition of silver nanoparticles. Electrochim. Acta 2016, 187, 286-292. [CrossRef]

174. Zhang, Y.; Xiao, S.; Li, H.; Liu, H.; Pang, P.; Wang, H.; Wu, Z.; Yang, W. A $\mathrm{Pb}^{2+}$-ion electrochemical biosensor based on single-stranded DNAzyme catalytic beacon. Sens. Actuators B Chem. 2016, 222, 1083-1089. [CrossRef]

175. Lei, Y.M.; Huang, W.X.; Zhao, M.; Chai, Y.Q.; Yuan, R.; Zhuo, Y. Electrochemiluminescence Resonance Energy Transfer System: Mechanism and Application in Ratiometric Aptasensor for Lead Ion. Anal. Chem. 2015, 87, 7787-7794. [CrossRef] [PubMed]

176. Zhou, Y.; Tang, L.; Zeng, G.; Zhang, C.; Xie, X.; Liu, Y.; Wang, J.; Tang, J.; Zhang, Y.; Deng, Y. Label free detection of lead using impedimetric sensor based on ordered mesoporous carbon-gold nanoparticles and DNAzyme catalytic beacons. Talanta 2016, 146, 641-647. [CrossRef] [PubMed]

177. Cui, L.; Wu, J.; Li, J.; Ju, H. Electrochemical Sensor for Lead Cation Sensitized with a DNA Functionalized Porphyrinic MetalOrganic Framework. Anal. Chem. 2015, 87, 10635-10641. [CrossRef] [PubMed]

178. Zhang, H.; Huang, S.; Yang, X.; Yuan, R.; Chai, Y. A SERS biosensor constructed by calcined ZnO substrate with high-efficiency charge transfer for sensitive detection of $\mathrm{Pb}^{2+}$. Sens. Actuators B Chem. 2021, 343, 130142. [CrossRef]

179. Wang, F.; Zhang, Y.; Lu, M.; Du, Y.; Chen, M.; Meng, S.; Ji, W.; Sun, C.; Peng, W. Near-infrared band Gold nanoparticles-Au film "hot spot" model based label-free ultratrace lead(II) ions detection via fiber SPR DNAzyme biosensor. Sens. Actuators B Chem. 2021, 337, 129816. [CrossRef]

180. Meng, J.; Huang, J.; Oueslati, R.; Jiang, Y.; Chen, J.; Li, S.; Dai, S.; He, Q.; Wu, J. A single-step DNAzyme sensor for ultra-sensitive and rapid detection of $\mathrm{Pb}^{2+}$ ions. Electrochim. Acta 2021, 368, 137551. [CrossRef]

181. Zhao, G.; Li, C.; Wang, X.; Liu, G.; Thuy, N.T.D. A Reusable Electrochemical Aptasensor for the Sensitive Detection of Pb(II) with an Electrodeposited AuNP-Modified Electrode based on the Formation of a Target-Induced G-Quadruplex. Int. J. Electrochem. Sci. 2021, 16, 150956. [CrossRef]

182. Wang, Y.; Zhao, G.; Zhang, G.; Zhang, Y.; Wang, H.; Cao, W.; Li, T.; Wei, Q. An electrochemical aptasensor based on gold-modified $\mathrm{MoS}_{2} / \mathrm{rGO}$ nanocomposite and gold-palladium-modified Fe-MOFs for sensitive detection of lead ions. Sens. Actuators B Chem. 2020, 319, 128313. [CrossRef]

183. Wu, H.; Wang, S.; Li, S.F.Y.; Bao, Q.; Xu, Q. A label-free lead(II) ion sensor based on surface plasmon resonance and DNAzyme-gold nanoparticle conjugates. Anal. Bioanal. Chem. 2020, 412, 7525-7533. [CrossRef]

184. He, Y.; Hu, X.; Gong, Z.; Chen, S.; Yuan, R. A novel electrochemiluminescence biosensor based on the self-ECL emission of conjugated polymer dots for lead ion detection. Microchim. Acta 2020, 187, 237-245. [CrossRef]

185. Jin, H.; Zhang, D.; Liu, Y.; Wei, M. An electrochemical aptasensor for lead ion detection based on catalytic hairpin assembly and porous carbon supported platinum as signal amplification. RSC Adv. 2020, 10, 6647-6653. [CrossRef]

186. Feng, D.; Li, P.; Tan, X.; Wu, Y.; Wei, F.; Du, F.; Ai, C.; Luo, Y.; Chen, Q.; Han, H. Electrochemiluminescence aptasensor for multiple determination of $\mathrm{Hg}^{2+}$ and $\mathrm{Pb}^{2+}$ ions by using the MIL-53 (Al)@CdTe-PEI modified electrode. Anal. Chim. Acta 2020, 1100, 232-239. [CrossRef] 
187. Chen, J.; Zhang, J.; Guo, Y.; Li, J.; Fu, F.; Yang, H.H.; Chen, G. An ultrasensitive electrochemical biosensor for detection of DNA species related to oral cancer based on nuclease-assisted target recycling and amplification of DNAzyme. Chem. Commun. 2011, 47, 8004-8006. [CrossRef]

188. Chen, D.; Li, B.; Jiang, L.; Duan, D.; Li, Y.; Wang, J.; He, J.; Zeng, Y. Highly efficient colorimetric detection of cancer cells utilizing Fe-MIL-101 with intrinsic peroxidase-like catalytic activity over a broad pH range. RSC Adv. 2015, 5, 97910-97917. [CrossRef]

189. Xue, Y.; Li, X.; Li, H.; Zhang, W. Quantifying thiol-gold interactions towards the efficient strength control. Nat. Commun. 2014, 5, 4348. [CrossRef]

190. Wang, M.; Mohanty, S.K.; Mahendra, S. Nanomaterial-Supported Enzymes for Water Purification and Monitoring in Point-of-Use Water Supply Systems. Acc. Chem. Res. 2019, 52, 876-885. [CrossRef]

191. Chey, C.O.; Ibupoto, Z.H.; Khun, K.; Nur, O.; Willander, M. Indirect determination of mercury ion by inhibition of a glucose biosensor based on $\mathrm{ZnO}$ nanorods. Sensors 2012, 12, 15063-15077. [CrossRef] [PubMed]

192. Santos, E.; Montenegro, M.C.B.S.M.; Couto, C.; Araújo, A.N.; Pimentel, M.F.; Da Silva, V.L. Sequential injection analysis of chloride and nitrate in waters with improved accuracy using potentiometric detection. Talanta 2004, 63, 721-727. [CrossRef] 